GROWTH OF VESICULAR STOMATITIS VIRUS IN MOSQUITO CELL LINES 


\title{
GROWTH OF VESICULAR STOMATITIS VIRUS IN MOSQUITO CELL LINES
}

\author{
by \\ Harvey Artsob, B.Sc., M.Sc。
}

A thesis submitted to the Faculty of Graduate Studies and Research in partial fulfillment of the requirements for the degree of Doctor of Philosophy.

Department of Microbiology and Immunology, McGill University, Montreal.

\author{
February, 1973.
}




\begin{abstract}
Cocal strain of vesicular stomatitis virus was propagated in Aedes albopictus and Aedes aegypti cell lines. Infection of the cell lines at $30^{\circ} \mathrm{C}$ resulted in a low titered virus infection involving only a small proportion of the cell population with no cytopathic effects. Virus titers in A. albopictus were increased by adsorption with DEAE dextran or by increasing temperature of incubation. Use of a high input multiplicity and incubation of cells at $37^{\circ} \mathrm{C}$ resulted in $100 \%$ infection of cell cultures allowing a limited electron microscopic study of virus development. Persistent infection was established in both mosquito cell lines and maintained for up to 60 passages with some change in properties of passaged virus. Characterization of carrier cultures indicated no role for antiviral factors in sontrolling virus infection, but most cells appeared to be genetically resistant. Treatment of persistently infected A. albopictus with actinomycin $D$ resulted in elevated virus titers.
\end{abstract}




\section{RESUME}

La souche "Cocal" du virus de la stomatite vésiculaire a été propagée dans des lignées cellulaires isolées d'Aedes albopictus et d'Aedes aegypti. L'infection des lignées cellulaires a $30^{\circ} \mathrm{C}$ produisit un faible taux d' infection virale $n$ ' affectant qu'une petite proportion de la population cellulaire ef ceci sans effets cytopathiques. Lors de l' infection de cellules d'A. albopictus, le titre du virus augmenta après adsorption de celui-ci sur DEAE dextran ou à la suite de l'élévation de la temperature d'incubation des cellules. L'utilisation d'un grand nombre de particules infectieuses ef $\mathrm{I}^{\prime}$ incubation à une température de $37^{\circ} \mathrm{C}$ résulta en l' infection de la totalité (100\%) de la culture cellulaire, permettant ainsi une étude sommaire du développement du virus à l'aide du microscope électronique. Une infection persistante a pu être établie chez les deux lignées cellulaires ef maintenue jusqu'au soixantieme (60e) passage; certains changements dans les propriétés du virus ainsi propagé furent observés. La caractérisation des cultures porteuses n'a pas permis d' incriminer des substances antivirales en tant qu'agents de contrôle de l' infection virale, mais l' on a noté que la plupart des cellules semblaient génétiquement résistantes. Le traitement de cellules

d' A. albopictus infectées de façon permanente avec de l'actinomycine D détermina une é lévation du titre viral. 


\section{ACKNOWLEDGEMENTS}

The author wishes to express his sincere gratitude to Dr. L. Spence for his supervision and interest throughout the course of this work. Appreciation is also expressed to Dr. P. Gill for his valuable criticism during the writing of this manuscript.

Sincere appreciation is also extended to Ms. Gail Deutsch and, in particular, Ms. Margaret Gomersall for cheerful assistance provided both in teaching electron microscopic techniques and in helping to prepare some of the electron photomicrographs that appear in this thesis.

The able assistance provided by Mr. Florestino Ribeiro and the late Mr. Leslie Single for the animal work is also acknowledged.

Thanks are also extended to Prof. S.l. Vas, Chairman of the Department of Microbiology and Immunology, and to the late Prof. R.W. Reed (former Chairman of the Department) for permission to carry out the work in this Department.

Finally, special thanks are due to Dr. S. Buckley of the Yale Arbovirus Research Unit for supplying the mosquito cell lines used in this project and for providing generously of her time during the author's brief stay at her laboratory.

The financial support from the Medical Research Council is gratefully acknowledged. 


\section{TABLE OF CONTENTS}

Page

ACKNOWLEDGEMENTS $\ldots \ldots \ldots \ldots \ldots \ldots \ldots \ldots \ldots \ldots \ldots \ldots \ldots \ldots$ i

LIST OF TABLES $\quad \ldots \ldots \ldots \ldots \ldots \ldots \ldots \ldots \ldots \ldots \ldots \ldots \ldots \ldots \ldots \ldots \ldots \ldots$

LIST OF FIGURES $\quad \ldots \ldots \ldots \ldots \ldots \ldots \ldots \ldots \ldots \ldots \ldots \ldots \ldots \ldots \ldots \ldots \ldots \ldots$

I. INTRODUCTION $\ldots \ldots \ldots \ldots \ldots \ldots \ldots \ldots \ldots \ldots \ldots \ldots \ldots \ldots \ldots \ldots$

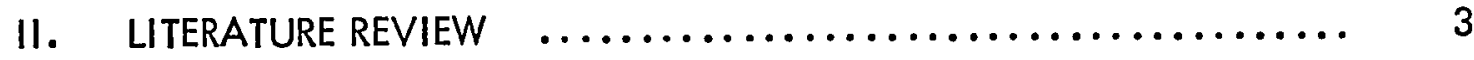

A. COCAL VIRUS - A MEMBER OF THE VSV GROUP $\ldots \ldots \ldots .3$

B. EPIDEMIOLOGY AND TRANSMISSION OF VSV $\ldots \ldots \ldots \ldots 4$

1. Vector Theories of Transmission $\ldots \ldots \ldots \ldots \ldots \ldots \ldots \ldots$........ 5

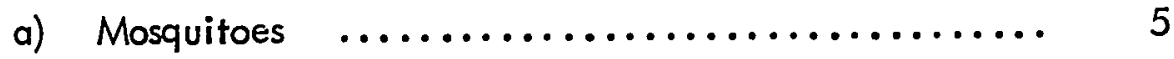

b) Horseflies and Deerflies $\ldots \ldots \ldots \ldots \ldots \ldots \ldots \ldots 6$

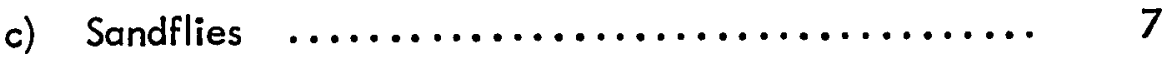

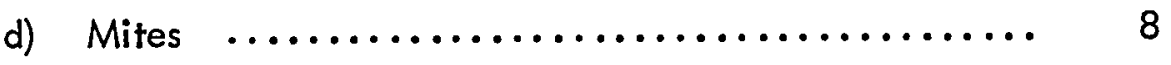

2. Transmission by Direct Contact and Fomites $\ldots \ldots \ldots . .8$

C. EXPERIMENTAL PROPAGATION OF VSV IN ARTHROPODS .. 9

D. INSECT TISSUE CULTURE $\quad \ldots \ldots \ldots \ldots \ldots \ldots \ldots \ldots \ldots \ldots \ldots \ldots$ 
1. History of Insect Tissue Culture $\ldots \ldots \ldots \ldots \ldots \ldots \ldots ., 11$

2. Status of Insect Tissue Culture $\ldots \ldots \ldots \ldots \ldots \ldots \ldots .16$

E. GROWTH OF ARBOVIRUSES IN ARTHROPOD TISSUE CULTURE 20

1. Primary Tick Tissue $\ldots \ldots \ldots \ldots \ldots \ldots \ldots \ldots \ldots \ldots . . . \ldots$

2. Antheraea eucalypti Cell Line $\ldots \ldots \ldots \ldots \ldots \ldots \ldots . . \ldots 22$

3. Primary Mosquito Tissue Culture $\ldots \ldots \ldots \ldots \ldots \ldots \ldots .23$

4. Continuous Mosquito Cell Lines $\ldots \ldots \ldots \ldots \ldots \ldots \ldots .25$

5. Drosophila melanogaster Cell Line $\ldots \ldots \ldots \ldots \ldots \ldots \ldots .39$

III. MATERIALS AND METHODS $\ldots \ldots \ldots \ldots \ldots \ldots \ldots \ldots \ldots \ldots \ldots, 40$

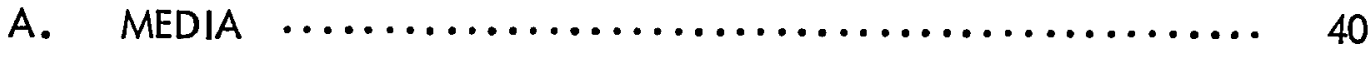

B. PREPARATION OF VIRUS POOLS $\ldots \ldots \ldots \ldots \ldots \ldots \ldots \ldots .40$

1. Cocal Virus $\ldots \ldots \ldots \ldots \ldots \ldots \ldots \ldots \ldots \ldots \ldots \ldots, 40$

2. Mayaro Virus $(\ldots \ldots \ldots \ldots \ldots \ldots \ldots \ldots \ldots \ldots \ldots \ldots \ldots, 41$

3. Nepuyo Virus $\ldots \ldots \ldots \ldots \ldots \ldots \ldots \ldots \ldots \ldots \ldots \ldots ., 41$

4. Flanders-Hart Park Virus $\ldots \ldots \ldots \ldots \ldots \ldots \ldots \ldots \ldots, 42$

C. PREPARATION OF tisSUE CUltURE MONOLAYERS $\ldots \ldots \ldots .42$

1. BHK-21 Cells $\ldots \ldots \ldots \ldots \ldots \ldots \ldots \ldots \ldots \ldots \ldots, 42$

2. LCells $\ldots \ldots \ldots \ldots \ldots \ldots \ldots \ldots \ldots \ldots \ldots \ldots \ldots \ldots \ldots, 43$

3. Chick Embryo Cells $\ldots \ldots \ldots \ldots \ldots \ldots \ldots \ldots \ldots \ldots .43$

4. A. albopictus Cells $\ldots \ldots \ldots \ldots \ldots \ldots \ldots \ldots \ldots . \ldots \ldots$

5. A. aegypti Cells $\ldots \ldots \ldots \ldots \ldots \ldots \ldots \ldots \ldots \ldots \ldots, 44$

iii. 
D. EXPERIMENTAL ANIMALS $\ldots \ldots \ldots \ldots \ldots \ldots \ldots \ldots \ldots \ldots, 45$

E. ANIMAL INOCULATIONS $\ldots \ldots \ldots \ldots \ldots \ldots \ldots \ldots \ldots . . . \ldots \ldots$

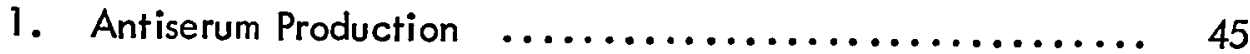

2. Experimental Inoculations $\ldots \ldots \ldots \ldots \ldots \ldots \ldots . . .46$

F. TITRATION OF VIRUS BY PLAQUE ASSAY $\ldots \ldots \ldots \ldots \ldots . . . .47$

G. Plaque NEUTRAlizATION TEST $\ldots \ldots \ldots \ldots \ldots \ldots \ldots \ldots ., 48$

H. INFECTION AND SAMPLING OF CELL CULTURES ........ 48

1. Infection of Monolayers $\ldots \ldots \ldots \ldots \ldots \ldots \ldots \ldots \ldots .48$

2. Sampling Procedure $\quad \ldots \ldots \ldots \ldots \ldots \ldots \ldots \ldots \ldots \ldots . .49$

a) Extracellular Virus $\ldots \ldots \ldots \ldots \ldots \ldots \ldots \ldots \ldots, 49$

b) Cell Associated Virus $\ldots \ldots \ldots \ldots \ldots \ldots \ldots \ldots . .49$

c) Assay for Infective Centers $\ldots \ldots \ldots \ldots \ldots \ldots \ldots \ldots, 50$

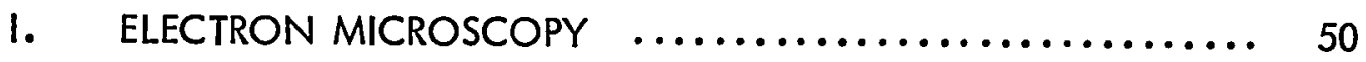

1. Cell Spread Technique $\ldots . \ldots \ldots \ldots \ldots \ldots \ldots \ldots \ldots . .61$

2. Thin Sectioning Technique $\ldots \ldots \ldots \ldots \ldots \ldots \ldots \ldots \ldots . .61$

J. GENERAL PLAN OF THE EXPERIMENTS $\ldots \ldots \ldots \ldots \ldots \ldots \ldots, 52$

1. Growth of Cocal in Different Cell Lines $\ldots . \ldots \ldots \ldots . .652$

2. Efforts to Increase Virus Titers in Mosquito Cells ....... 53

3. Studies on Persistent Infection of Mosquito Cells ....... 53

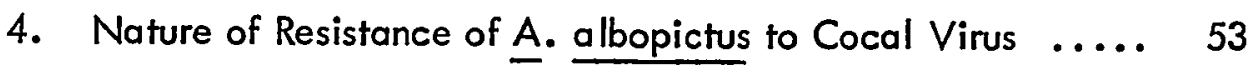




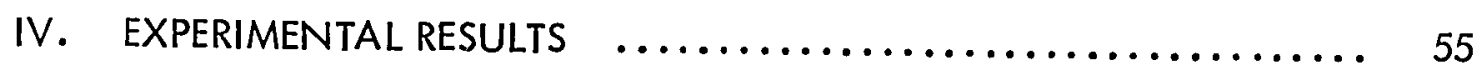

A. PRELIMINARY EXPERIMENTS $\ldots \ldots \ldots \ldots \ldots \ldots \ldots \ldots \ldots . \ldots \ldots$

1. Arbovirus Check of Mosquito Cell Lines $\ldots . . . \ldots \ldots . .65$

2. Mycoplasma Check of Mosquito Cell Lines .......... 55

3. Antibody Titers of Immunized Animals $\ldots \ldots \ldots \ldots \ldots . . \ldots 5$

B. GROWTH OF COCAL IN DIFFERENT CELL LINES ........ 56

1. Adsorption of Virus to Mosquito and L Cells .......... 56

2. Growth of Cocal in Mosquito and L Cells $\ldots . . . . . . . . \quad 57$

a) L Cells $\ldots \ldots \ldots \ldots \ldots \ldots \ldots \ldots \ldots \ldots \ldots \ldots \ldots, 57$

b) A. albopictus $\ldots \ldots \ldots \ldots \ldots \ldots \ldots \ldots \ldots \ldots, 59$

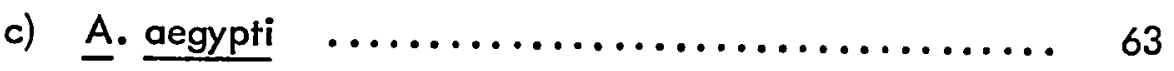

3. Level of Susceptibility of Different Cell Lines ........ 63

C. EFFORTS TO INCREASE VIRUS TITERS IN MOSQUITO CELLS . 65

1. Effect of DEAE Dextran $\ldots . \ldots \ldots \ldots \ldots \ldots \ldots \ldots . . . \ldots 6$

2. Effect of Serum Concentration $\ldots \ldots \ldots \ldots \ldots \ldots \ldots .69$

3. Effect of Temperature $\ldots \ldots \ldots \ldots \ldots \ldots \ldots \ldots \ldots$. 71

a) Infection with Low Input Multiplicity of Virus .... 71

b) Infection with High Input Multiplicity of Virus .... 71

D. STUDIES ON PERSISTENT INFECTION OF MOSQUITO

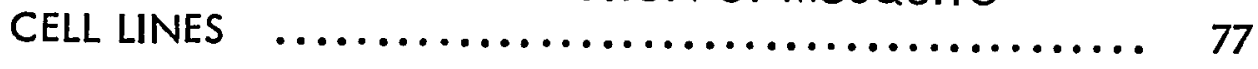

1. Development of Persistently Infected Cultures ......... 77

2. Maintenance of Persistent Infection under Immune Serum .. 80 
3. Virus Production during Growth of A. albopictus Persistently Infected Cells $. . . . . . . . . \ldots \ldots . . . . .$.

4. Relative Sensitivities of Different Host Systems to Cocal Virus

5. Studies on Small Plaque Cocal from Persistently Infected Cells

a) Growth of Small Plaque Pool $\ldots \ldots \ldots \ldots \ldots \ldots \ldots . .84$

b) Effect of Temperature and Cell Lines on Plaque Size - 87

c) Effect of Possible Plaque Inhibitors $\ldots \ldots \ldots \ldots \ldots .87$

d) Growth of Small Plaque Virus in LCells ......... 89

e) Growth of Small Plaque Virus in A. albopictus Cells . 91

f) Virulence of Small Plaque Virus $\ldots . \ldots \ldots \ldots \ldots$. s1

E. NATURE OF RESISTANCE OF A. ALBOPICTUS TO

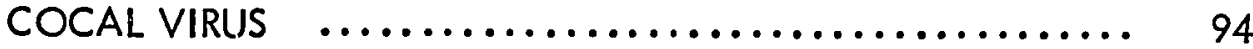

1. Incubation of Cells at 30 and $37^{\circ} \mathrm{C} \quad \ldots \ldots \ldots \ldots \ldots . .94$

2. Superinfection of Persistently Infected Cells $\ldots . . . \ldots .94$

a) Superinfection with Homologous Virus $\quad \ldots . \ldots \ldots \ldots .94$

b) Superinfection with Unrelated Arboviruses $\ldots \ldots \ldots .96$

3. Antiviral Factors in Mosquito Tissue Culture Medium .... 98

a) Survival of Virus in Different Media $\ldots \ldots \ldots \ldots . .98$

b) Virus Titer in Cells under Different Media $\ldots \ldots \ldots, 102$

4. Assays for Interferon Production by Mosquito Cells ..... 103

5. Effect of Inhibitors on Virus Titer ................ 105 
a) Actinomycin $D \quad \ldots \ldots \ldots \ldots \ldots \ldots \ldots \ldots \ldots \ldots, 105$

b) Puromycin $\ldots \ldots \ldots \ldots \ldots \ldots \ldots \ldots \ldots \ldots \ldots \ldots, 105$

F. ELECTRON MICROSCOPY $\ldots \ldots \ldots \ldots \ldots \ldots \ldots \ldots . .109$

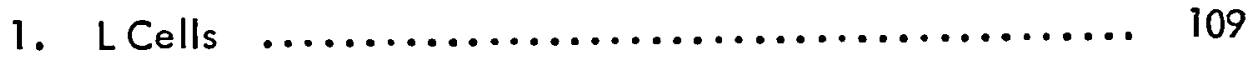

a) Viral Contaminant of LCells $\ldots \ldots \ldots \ldots \ldots \ldots, 109$

b) Cocal Infection of L Cells $\ldots \ldots \ldots \ldots \ldots \ldots \ldots, 110$

2. Cocal Infection of $\underline{A}$. albopictus Cells $\ldots \ldots \ldots \ldots \ldots, 110$

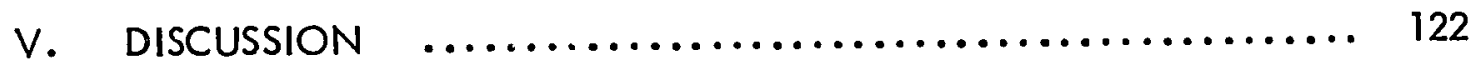

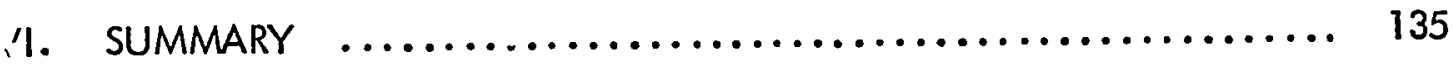

VII. CONTRIBUTIONS TO KNOWLEDGE $\ldots \ldots \ldots \ldots \ldots \ldots \ldots \ldots, 137$

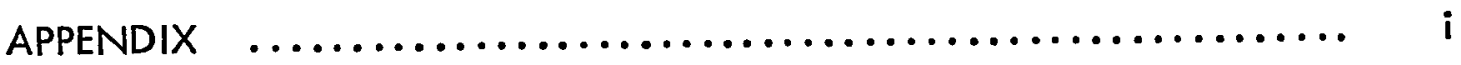

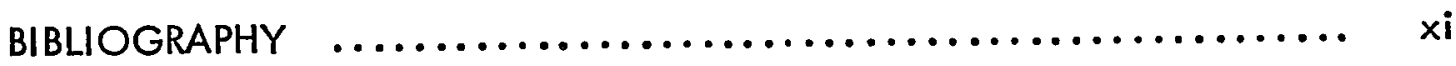

vii. 


\section{LIST OF TABLES}

Table No.

1. Established cell lines from mosquito species $\quad \ldots \ldots \ldots \ldots \ldots . . .14$

2. Description of cells from continuous insect cell lines $\ldots . . . . \quad 18$

3. Key to arboviruses discussed in Literature Review ......... 26

4. Growth of arboviruses in continuous mosquito cell lines ..... 31

5. Adsorption of Cocal virus to $A$. albopictus and $L$ cells at $30^{\circ} \mathrm{C}$ with an input multiplicity of $0.1 \ldots \ldots \ldots \ldots . \ldots . \ldots 5$

6. Effect of input multiplicity on virus titer in A. albopictus ... 62

7. Limits of susceptibility of cell lines to Cocal virus ........ 65

8. Effect of temperature on virus production in A. albopictus

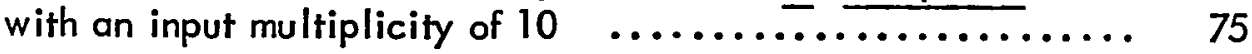

9. Effect of passage on persistent infection of mosquito cell lines . 79

10. Size of plaques produced at $37^{\circ} \mathrm{C}$ in different cell lines infected with Cocal virus $48 \mathrm{hr}$ postinfection $\ldots \ldots \ldots \ldots \ldots \ldots . . . .68$

11. Intracerebral challenge of adult mice with normal and small

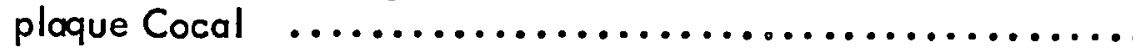

12. Effect of transfer of infected cells from 37 to $30^{\circ} \mathrm{C}$ on virus titer in A. albopictus

13. Survival of virus in tissue culture maintenance media at $30^{\circ} \mathrm{C} \quad$. 102

14. Interferon assays in A. albopictus $\ldots \ldots \ldots \ldots \ldots \ldots . \ldots . \ldots . \ldots . \ldots$ 
Table No.

Page

15. Effect of actinomycin D on virus titer in A. albopictus

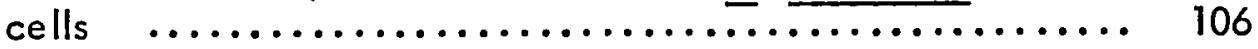

16. Effect of puromycin on titer of $\mathrm{A}$. albopictus persistently infected cells

17. Summary of Cocal carrier culture infection of A. albopictus -. 


\section{LIST OF FIGURES}

Figure No.

Page

1. Growth of Cocal virus in $\mathrm{L}$ cells at $30^{\circ} \mathrm{C}$ with an input

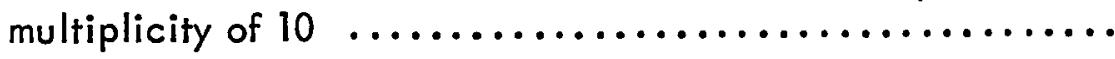

2. Growth of Cocal virus in A. albopictus cells at $30^{\circ} \mathrm{C}$ with input multiplicities of 0.1 and $10 \ldots \ldots \ldots \ldots \ldots \ldots$

3. Long and short particles of Cocal concentrated chick embryo pool

4. Growth of Cocal virus in A. aegypti cells at $30^{\circ} \mathrm{C}$ with input multiplicities of 0.1 and $\overline{10}$

5. Effect of DEAE dextran during Cocal virus adsorption on virus titer in A. albopictus cells at $30^{\circ} \mathrm{C} \ldots \ldots \ldots \ldots \ldots \ldots$

6. Effect of DEAE dextran during Cocal virus adsorption on virus titer in A. aegypti cells at $30^{\circ} \mathrm{C} \quad \ldots \ldots \ldots \ldots \ldots \ldots \ldots$

7. Effect of serum concentration on Cocal virus titer in A. albopictus cells at $30^{\circ} \mathrm{C}$ infected with an input multi-

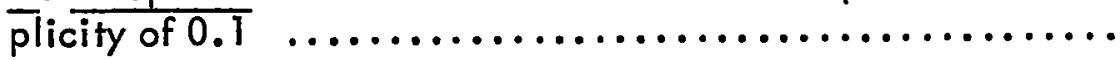

8. Effect of temperature on Cocal virus titer in A. albopictus cells infected with an input multiplicity of 0.1

9. Effect of temperature on Cocal virus titer in A. albopictus cells infected with an input multiplicity of 10

10. Effect of temperature on Cocal virus titer in A. aegypti cells

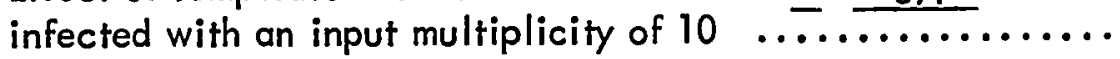

11. Effect of Cocal antiserum on Cocal persistent infection of

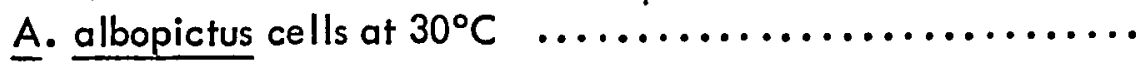

12. Cocal virus titer during growth of $A$. albopictus persistently infected cells at $30^{\circ} \mathrm{C}$ 
Figure No.

13. Comparative sensitivities of different host systems to Cocal virus

14. Cocal virus plaques in chick embryo $\ldots \ldots \ldots \ldots \ldots \ldots . \ldots 6$

15. Growth of normal and small plaque Cocal virus in $L$ cells at $30^{\circ} \mathrm{C}$ with an input multiplicity of 0.1

16. Growth of normal and small plaque Cocal virus in A. albopictus cells at $30^{\circ} \mathrm{C}$ with an input multiplicity of $0.1 \ldots \ldots \ldots$

17. Cocal virus superinfection of $\mathrm{A}$. albopictus cells persistently infected with Cocal virus at $30^{\circ} \mathrm{C} \ldots \ldots \ldots \ldots \ldots \ldots . . \ldots$

18. Flanders virus superinfection of $A$. albopictus cells persistently infected with Cocal virus at $30^{\circ} \mathrm{C}$

19. Mayaro virus superinfection of $A$. albopictus cells persistently infected with Cocal virus at $30^{\circ} \mathrm{C}$

20. Nepuyo virus superinfection of $A$. albopictus cells persistently infected with Cocal virus at $30^{\circ} \mathrm{C}$

21. Effect of actinomycin $D$ on virus titer of $A$. albopictus persistently infected cells at $30^{\circ} \mathrm{C}$

22. Viral contaminant of $L 929$ cell line $\ldots \ldots \ldots \ldots \ldots \ldots \ldots . . . . . .109$

23. Cocal virus budding from plasma membrane of an infected L cell

24. Cocal virus maturation in L cells

25. Budding of Cocal virus from infected $L$ cells $\ldots \ldots \ldots \ldots \ldots \ldots$

26. Cross section of A. albopictus cell infected with Cocal virus .. 114

27. Cocal virus in intracytoplasmic vesicle of A. albopictus cell .. 115 
Figure No.

28. Cocal virus in intrucytoplasmic vesicles of A. albopictus cells

29. Cocal virus in intracytoplasmic vacuoles of $\underline{A}$. albopictus cells

30. Budding of Cocal virus in infected A. albopictus cells ..... 118

31. Cocal virus from A. albopictus cells prepared by cell spread method 


\section{INTRODUCTION}

Vesicular Stomatitis Virus (VSV) is a bullet-shaped virus of helical symmetry which has been classified both as an arbovirus and as a rhabdovirus (Wilner, 1969). VSV is best known as the causative agent of an infection of cattle, horses, and pigs characterized by vesicular eruptions, principally on the buccal mucosa and sometimes on the skin of the feet (Merck Veterinary Manual, 1967). One serotype of VSV, Cocal virus, has also been implicated in an epizootic among forest rodents (Jonkers et al., 1964a).

Although VSV has been classified as an arbovirus and has been isolated in nature from mosquitoes (Sudia et al., 1967; Jonkers et al., 1965), sandflies (Peralta and Shelokov, 1966; Shelokov and Peralta, 1967; Tesh ef al., 1971), and mites (Jonkers et al., 1964a), the exact role of arthropods in the transmission of the disease has not been defined.

VSV has the potential for multiplying in a wide range of hosts. Nearly all mammalian species can be infected with VSV under experimental conditions (Howatson, 1970) and Hurlbut and Thomas (1969) have shown that VSV can multiply in 10 different arthropod species.

In vitro studies have also revealed that VSV can multiply in a wide range of cells from different animal species including human, other primate, bovine, murine, hamster, marsupial, reptile, fish, bird, and insect (Johnson et al.., 
1969; Buckley 1969). Whereas mammalian cells infected with VSV tend to readily support growth of virus with accompanying cytopathic effect (CPE), insect cells have tended to allow only a limited replication of virus without accompanying CPE. It is of interest to do a comparative study of growth of an arbovirus in both vertebrate and mosquito cells. Such studies may show whether virus multiplies in like manner in phylogenetically diverse hosts and may help to uncover some of the factors leading to resistance of mosquito cells to cytolytic infection such as possible production of antiviral factors.

At present, numerous studies have been published concerning growth of arboviruses in arthropod cells but most reports have been of a qualitative nature simply to report which viruses will multiply and to what titer. This project has been undertaken to enlarge studies of growth of VSV in mosquito cells, to try to better define the type of infection that ensues, and possibly to uncover some of the mechanisms governing the type of regulated non-cytopathic infection that occurs.

It is believed that such in vitro investigations may provide a useful adjunct to epidemiological studies. Mosquito cell lines have tended to show host specificity in ailowing growth of only mosquito borne arboviruses (with the exception of only two tick borne arboviruses), and the type of low titered non-cytolytic infection found in vitro simulates the in vivo conditions where arboviruses multiply in, but apparently do not harm, the infected insect. Therefore, enlightenment of regulatory factors operating during in vitro infections may provide valuable insight as to what is occurring in vivo. 


\section{LITERATURE REVIEW}

\section{A. COCAL VIRUS - A MEMBER OF THE VSV GROUP}

Cocal virus was first isolated in Trinidad from a pool of mites from the laelaptid genus Gigantolaelaps removed from the terrestrial rice rat, Oryzomys laticeps velutinus (Jonkers et al., 1964a). Subsequent isolations of Cocal virus were made in Brazil in 1962 also from Gigantolaelaps mites removed from a rodent Oryzomys goeldii. Later, in the same year, virus was isolated in Trinidad from another rodent species (Heteromys a. anomalus), from a pool of Culex sp. mosquitoes, and from a sentinel baby mouse (Jonkers et al., 1965).

Jonkers et al. (1964a) showed by complement fixation (CF) and neutralization $(N)$ tests that Cocal was related to VSV type Indiana but not to VSV type New Jersey. Halonen ef al. (1968) confirmed by hemagglutination inhibition test that Cocal was closely related serologically to VSV Indiana, and were able to demonstrate a low degree of cross reaction between Cocal and VSV type New Jersey. Federer et al. (1967) compared Cocal virus to other isolates of VSV and proposed that VSV type Indiana, Cocal virus, and a recent Brazilian isolate called A logoas virus should be classified as VSV Indiana types I, II, and III, respectively. Cartwright and Brown (1972) observed that whereas intact virus particles of different VSV serotypes showed little cross reaction in either CF or $N$ tests, the infective 
skeleton-like structures produced by uncoating virus and the infective ribonucleoprote in produced by disruption of virus were neutralized by either homo- or heterotypic antisera and considerable cross reactivity was demonstrated in the CF test. Thus, it would appear that the type and strain specificity of different VSV serotypes are determined by an antigen located on the surface projections.

VSV has been classified by Wilner (1969) both as an arbovirus and as a rhabdovirus. The classification as an arbovirus is based on epidemiological data (Hanson and Brandly, 1957; Jonkers et al., 1964a) and on the isolation of these viruses from, and propagation in, arthropods (Mussgay and Suárez, 1962; Jonkers et al., 1964a; Jonkers et al., 1965; Shelokov and Peralta, 1967; Sudia, 1967; Jergold et al. , 1968). The classification as a rhabdovirus is based on the bullet shape morphology and manner of replication (Howatson and Whitmore, 1962; Ditchfield and Almeida, 1964; Bergold and Munz, 1967).

\section{B. EPIDEMIOLOGY AND TRANSMISSION OF VSV}

Vesicular stomatitis is a viral disease of bovine, equine, and porcine animals but which may also infect man. It has been a disease of considerable economic importance in the western hemisphere where it is a recurrent cause of economic loss to the U.S. beef and dairy industries (Ellis and Kendall, 1964). Vesicular stomatitis has also been a source of concern due to its clinical similarity to foot-and-mouth disease. 
VSV is especially prevalent in countries bordering the Caribbean Sea, particularly Mexico, Venezuela, and Colombia (Howatson, 1970). The disease appears to spread north each season often only a short distance, sometimes into the southern United States, and occasionally as far north as Canada. In northern latitudes the disease generally reaches a peak in the late summer and fall and dies out in October.

Present epizootiological data make interpretation of the mode(s) of transmission of VSV very difficult but numerous possibilities exist.

\section{Vector Theories of Transmission}

The seasonal incidence and pattern of spread of the disease led to the suggestion that an arthropod vector may be involved in transmission of VSV (Hanson, 1952). Numerous arthropod species have been implicated including mosquitoes of various species chiefly Culex and Aedes, horseflies (Tabanus sp.) and deerflies (Chrysops sp.), Phlebotomus sandflies (esp. Lutzomyia sp.), and mites (Gigantolaelaps genus).

a) Mosquitoes

Mosquitoes have been implicated in that they are most active during warm months when outbreaks of vesicular stomatitis in livestock and Cocal virus infection in rodents occur, and are absent during the cold or dry season. The larvae 
require water for their development and the adults are found in greatest numbers in cool damp places. Furthermore, VSV Indiana has been isolated in nature from Aedes dorsalis (Sudia et al., 1967) and Cocal strain of VSV has been isolated from Culex sp. of mosquitoes (Jonkers et al., 1965).

Two arguments exist against the mosquito theory. One is the small number of isolations of VSV from mosquitoes during an outbreak. For example, Jonkers ef al. (1965) noted that during the Cocal epizootics of 1961 and 1962 , only one isolation was made from the thousands of mosquitoes examined. This suggested that mosquitoes probably were not the principal agents responsible for Cocal transfer during epizootic periods. Also, animals infected either naturally or experimentally tended to produce low viremia (Jonkers et al., 1964b; Hanson and Brandly, 1957; Kowalczyk et al., 1955; Johnson et al. , 1969) or,where high virus titers occurred, the animals died (Johnson ef al., 1969) which argues against mosquito or any other arthropod borne transmission. However, Donaldson (1970) has recently shown that bats (Myotis lucifugus) infected with Cocal virus produced a significant viremia apparently capable of maintaining an arthropod-vertebrate virus cycle.

b) Horseflies and Deerflies

As with mosquitoes, these diptera require cool wet places and have been mentioned as possible vectors of VSV. These postulated vectors are thought to trans- 
mit virus mechanically from infected vesicle fluid or saliva (Kowalczuk et al., 1955; Ferris ef al., 1955). Ferris et al. (1955) have demonstrated mechanical transmission of VSV type New Jersey from one embryonated egg to another by horseflies, deerflies, and mosquitoes of various species.

\section{c) Sandflies}

Numerous isolations have been made of VSV Indiana from pools of phlebotomine sandflies (Peralta and Shelokov, 1966; Shelokov and Peralta, 1967; Tesh et al., 1971). In a Panama survey, Tesh et al. (1969) noted that antibodies to VSV Indiana occurred mainly in arboreal and semiarboreal species of animals and postulated that arboreal sandflies and mosquitoes may be involved in transmission of VSV type Indiana. Johnson et al. (1969) postulated an intriguing role for phlebotomine sandflies in the transmission of VSV Indiana. They proposed that VSV Indiana is basically a plant virus which is capable of infecting Phlebotomus (and possibly other insects) after ingestion of plant juice. The virus after replication in the Phlebotomus sp. is then capable of replicating in vertebrates.

Tesh ef al. (1972) have recently demonstrated that experimentally infected phlebotomine sandflies (L. trapidoi and L. ylephiletrix) are capable of transmission of VSV Indiana transovarially to their progeny. If this occurs in nature, it provides a possible mechanism for maintenance of virus without a vertebrate host reservoir. 
d) Mites

Cocal virus has been isolated from Gigantolaelaps genus of mites in both Trinidad and Brazil (Jonkers et al., 1964a) and a mechanical mode of transmission involving mites was proposed by Jonkers et al. (1964b). They speculated that infected mites might bite rodents which would scratch and cause small wounds in which the virus would multiply infecting other mites. However, this could only be a survival mechanism for the virus and mites apparently are not involved in causing rapidly spreading outbreaks.

\section{Transmission by Direct Contact and Fomites}

Another suggested mode of transmission of VSV is by direct contact between animals through infected vesicle fluid and saliva or via fomites such as drinking buckets, fodder and nose rings (Hanson, 1952). These theories gain support from survival time of the virus $(3-4$ days in saliva) and from the partial success of contact experiments. However, abrasions of the skin appear necessary for virus transmission.

Jonkers (1967) proposed that animals were not essential to the life cycle of VSV. He suggested that virus was present in the pasture on the soil or vegetation and was introduced into the animals through minor lesions on the mouth or other hairless areas. Hanson (1968) noted, however, that this would not explain survival of the virus between epizootics. Furthermore, farm to farm spread sometimes 
occurred suggesting that the agent was not resident in the pasture.

\section{EXPERIMENTAL PROPAGATION OF VSV IN ARTHROPODS}

Mussgay and Suárez (1962) infected A. aegypti with VSV Indiana both by intrathoracic inoculation and by ingestion, and were able to demonstrate multiplication of VSV in these mosquitoes as well as transmission by bite to young mice. Since an arbovirus is defined as a virus capable of infecting vertebrates and of multiplying in the body of arthropods (Casals, 1961), the authors concluded that VSV should be considered as an arbovirus.

The ability of VSV to replicate in mosquitoes was also demonstrated by Jonkers et al. (1964a) who propagated Cocal virus in Culex pipiens quinquefasciatus (Say) mosquitoes with transmission of virus to young mice.

Periès et al. (1966) showed that VSV is capable of replicating in other diptera when they were able to successfully propagate the virus in Drosophila. Successive passages of virus in this new host allowed se lection of a variant called $V S V_{D}$. Infection with $V S V_{D}$ resulted in reduced longevity of flies as well as reduced fertility of females (Printz, 1969).

Bergold et al. (1968) did an extensive study of multiplication of both VSV Indiana and New Jersey in A. aegypti and were able to demonstrate virus replication in eight different organs including brain, salivary gland, dorsal diverticulum, thoracic ganglion, ventral diverticulum, abdominal ganglion, midgut, 
and hindgut. Electron microscopic studies revealed virus particles that were mainly hemispherical at both ends but very few bullet-shaped VSV particles were observed. Both serotypes of VSV were transmitted from infected mosquitoes to baby mice. However, the efficiency of transmission of the New Jersey strain was sufficiently low to lead the authors to speculate that A. aegypti does not play an important role as a vector in nature for the New Jersey strain. A possible role of A. aegypti in transmission and maintenance of VSV Inaiiana in nature was discussed. Harlbut and Thomas (1969) demonstrated a wide propagative potential of Cocal virus in arthropods. Cocal virus was found to multiply in 10 of 11 arthropods inoculated including bedbug (Cimex lectularius), black carpet beetle (Attagenys piceus), Indian meal moth (Plodia interpunctella), soft tick (Ornithodoros savignyi), hard tick (Dermacentor andersoni), and several species of mosquitoes (Culex tritaeniorhynchus, Culex pipiens, Aedes albopictus, A. aegypti, Anopheles quadrimaculatus). Virus was found to persist in high titer in the infected arthropods for long periods without apparent ill effect. The extensive arthropod host range of Cocal virus led the authors to speculate that this virus might be a prototype arbovirus that had originated in arthropods.

Tesh et al. (1971) infected wild caught sandflies (L. trapidoi) with VSV Indiana by feeding on viremic infant hamsters. Titers of VSV were found to increase rapidly in infected sandflies and virus transmission by bite was observed as early as three days post infection. Further studies by Tesh ef al. (1972) demonstrated that VSV Indiana could be transmitted transovarially by two species of experimentally 
infected phlebotomine sandflies (ㄴ. trapidoi and $\underline{L}$. ylephiletrix). Virus was recoverable from eggs, larvae, pupae, and $F_{1}$ adults and titers of virus were found to have increased by four logs showing that virus multiplication had actually occurred during these developmental stages.

\section{INSECT TISSUE CULTURE}

\section{History of Insect Tissue Culture}

Grace (1967b) has catalogued the early history of insect cell culture into three separate phases. The first phase refers to studies where insect tissues were maintained in vitro for prolonged periods of time with little actual cell growth. Early studies were primarily aimed at studying mechanisms of meiosis and mitosis, and simple media of salts and sugars often supplemented with hemolymph were adequate for these early studies (Goldschmidt, 1915; Lewis, 1916; Glaser, 1917).

The second phase in the history of insect cell culture involved a concerted effort to grow insect tissues for extended periods by supplementing media with various extracts both from insects and vertebrates, so that all factors deemed necessary for cell growth were provided. Numerous studies were reported (Trager, 1935; Hibbard, Gavrilov and Cowez, and Gottschewski and Fischer as cited in a review by Grace 1967b), but although cells were found to survive longer in these more complex media, there was little actual improvement in the growth of cells. These studies, however, led to the third phase where specific informa- 
tion acquired from earlier studies began to be used to compose media that allowed a limited amount of cell growth. A notable achievement occurred when Wyatt (1956) was able to grow cells from ovarian tissue of the silkworm Bombyx mori for a two to three week period in a medium that attempted to simulate the natural constituents in silkworm hemolymph. To this synthetic medium was added $10 \%$ heat treated silkworm hemolymph.

Grace introduced several changes in the formulation of Wyatt's medium, such as addition of vitamins, alteration of certain cations, change in osmotic pressure of the medium, etc. and was able to grow and maintain cells from various species of moths for periods of up to 1 year (Grace, 1958a, b, $+c$ ). These studies culminated in the development of the first continuous cell line from insect tissue when Grace (1962) successfully established 4 strains of cells from ovarian tissue of the saturniid Antheraea eucalypti as continuous cell lines.

Grace employed this same medium in subsequent studies to establish continuous cell lines from the mosquito A. aegypti L (Grace, 1966) and the silkworm B. mori L (Grace, 1967a). These cell lines established by Grace are still in use today.

Other workers about this time were also attempting to establish cell lines from mosquito tissue. Kitamura (1966) cultured ovarian tissue from $\underline{A}$. albopictus, A. aegypti, and Culex molestus, and was able to subculture cells of Aedes up to the eighth passage. Similar efforts to establish mosquito cell lines met with little success (Peleg, 1965; Peleg, 1966) until Singh reported the establish- 
ment of continuous cell cultures from larvae of $\underline{A}$. albopictus (Skuse) and $\underline{A}$. aegypti $L$ (Singh, 1967). Singh established his cell lines using a culture medium originally derived by Mitsuhashi and Maramarosch (1964) for leaf hopper tissue culture. Singh's culture medium represented an important step forward in that fetal bovine serum was added instead of insect hemolymph. Alleviation of the requirement for insect hemolymph represented an important advance, as insect hemolymph is neither plentiful nor easily available to most laboratories.

Since the establishment of continuous mosquito cell lines by Grace and Singh, numerous other reports have appeared in the literature, and there are now about 14 continuous cell lines that have been derived from mosquito tissue. A summary of the established cell lines and some of their characteristics is presented in Table 1.

An examination of Table 1 reveals that most cell lines have been derived from larval tissue. This is not surprising since embryonic tissue often serves as a fruitful source of material for derivation of various vertebrate cell lines. However, it is also desirable to derive cell lines from pupal and adult stages of the mosquito as cells derived from these stages may be expected to be more closely related to structures and cells of the adult mosquito. It is for this reason that the cell lines derived by Sweet and Dupree (1968), Hsu ef al. (1970) and by Kitamura (1970) from mosquito pupal and adult tissue are of particular interest and hold hope for derivation of cell lines from various tissues such as mosquito salivary glands. 
TABLE 1

$\underline{\text { Species }}$

Aedes aegypti L

A. aegypti

Aedes a lbopictus

A. aegypti

Aedes vexans

Culiseta inornata

A. aegypti

A. aegypti
Established Cell Lines from Mosquito Species ${ }^{a}$
Stage of Explant

4th larval instar

1st larval instar

embryos

pupse

adult

Ist larval instar

1st larval instar

\section{Medium}

Grace

Mitsuhashi and

Maramorosch

$$
\begin{gathered}
\text { Kitamura/ } \\
\text { Trager }
\end{gathered}
$$

Grace

(modified)

Grace
(modified)

Mitsuhashi
and

Miaramorosch

Maramorosch/

Kitamura/VP 12
Mitsuhashi and
Chromosome Complement

Polyploid

(16 $\mathrm{n}$ or higher)

Diploid

Diploid

Polyploid

Polyploid

(16n to $64 n$ )

Diploid

Diploid
( $16 n$ to $128 n$ ?)

\section{Reference}

Grace, T.D.C.

(1966)

Singh, K.R.P.

(1967)

Peleg, J.

(1968)

Sweet, B.H. and

Dupree, L.T. (1968)

Sweet, B.H. and Dupree, L.T.

(1968)

Bhat, U.K.M. and Singh, K.R.P.

$$
\text { (1969) }
$$

Varma, M.G.R. and Pudney, M. (1969)
(To be continued) 
TABLE 1 (Continued)

$\underline{\text { Species }}$

Anopheles stephensi

Aedes vittatus

Aedes w-albus

Culex quinquefasciatus

(Say)

Culex molestus

Anopheles stephensi
Established Cell Lines from Mosquito Species ${ }^{a}$

Stage of Explant

$\underline{\text { Medium }}$

Chromosome Complement

Reference

1st larval instar

Grace

(modified by Schneider)

Diploid

Schneider, I.

(1969)

1st larval instar

Grace

(modified by Schneider)

Diploid

Diploid/

Polyploid

Maramorosch

Ist larval instar

Maramorosch

adult

M 199 and other components as per Hsu ef al.

adult

BCM / M 199

Diploid

Diploid

Diploid
Bhat, U.K.M. and Singh, K.R.P.

$(1970)^{b}$

Singh, K.R.P. and

Bhat, U.K.M.

$(1970)^{b}$

Hsu, S.H. etal. (1970)

Kitamura, S. (1970)

Pudney, M. and Varma, M.G.R. (1971)

a Table reproduced with modification from Schneider (1971)

b Cited as personal communication by Schneider (1971) 
There are numerous reports concerning development of primary cell lines from mosquitoes and other insects. As Grace has observed (1969), there is presently little difficulty in growing tissues in primary culture from a large number of insects. These primary cultures are of great value especially for virus studies, but they do not negate the need for continuous cell lines where less variability and greater reproducibility can be expected between cultures.

Continuous cell lines have been established from a number of insects other than mosquitoes. These include Drosophila melanogaster from the order Diptera (Echalier and Ohanessian, 1968), Periplaneta americana from the order Blattariae (Landureau, 1968), Agallia constricta from the order Hemiptera (Chiu et al., 1967) and numerous species from the order Lepidoptera including A. eucalypti (Grace, 1962), B. mori (Grace, 1967), Carpocapsa pomonella (Hink and Ellis, 1971), Chilo suppressalis (Mitsuhashi, 1967), Heliothis zea (Hink and Ignoffo, 1970), Trichoplusia ni (Hink, 1970), and Samia cynthia (Chas and Ball, 1971). Attempts have also been made to establish cell lines from tick tissue but with limited success. Numerous primary cultures have been grown (Rehacek, 1971) but, at present, no continuous cell lines have been established.

\section{Status of Insect Tissue Culture}

Several problems still exist in insect tissue culture. The factors operative in the establishment of a continuous cell line are poorly understood and it is 
very difficult at present to understand or control conditions that allow one particular type of cell(s) to arise from primary explants (Brooks and Kurtti, 1971). This problem is particularly acute in insect cell culture since numerous insects are often pooled together to provide sufficient tissue for establishing a cell line. Virtually all established insect cell lines have been set up in this manner and this makes it particularly hard to achieve a relatively pure culture of one identified cell type. At present, most established cell lines tend to consist of a mixture of morphologically different cells. A description of cells found in various established insect cell lines is presented in Table 2.

It is not known why different morphological cell types tend to be found nor is the relationship between these different cells understood. Suitor et al. (1966) cloned Grace's A. aegypti cell line and found evidence that a single clone of spindle-shaped cells gave rise to a large number of round daughter cells. As the cells increased in number, the spindle shape resumed. This would indicate that different cell shapes found in A. aegypti merely represent morphological variants of the same cell type. This observation contrasts with that of Grace (1968) who obtained ten morphologically different clones from his $\underline{A}$. eucalypti cell line. One unfortunate tendency in insect cell culture has been to select growth media on the basis of availability rather than suitability despite the fact that insect hemolymph varies greatly in composition between different orders, families, genera, and even species. This necessitates a process of adaptation for insect cells which is often a long and tedious process, and what subsequent effect 
18.

TABLE 2

Description of Cells from Continuous Insect Cell Lines

Cell Line

Description of Cells

Reference

Antheraea eucalypti

polygonal cells $20-40 \mu$ diameter; fibroblastic cells $15-20 \mu$ diameter;

Grace

round cells $10-15 \mu$ diameter

Aedes aegypti

spindle-shaped cells $40-50 \mu$ long

Grace

and $8-10 \mu$ wide; round cells

(1966)

approx. $20 \mu$ diameter

Bombyx mori

spind le-shaped cells $50-70 \mu$ long and 12-25 $\mu$ wide; slightly spindleshaped to round cells $18-30 \mu$ diameter

A. aegypti

epithelial type cells; outgrowth from hollow vesicles

Grace

(1967a)

Aedes a lbopictus

round cells 6-20 $\mu$ diameter; spindleshaped cells $7-20 \mu$ wide and $15-90 \mu$ long; binucleated round cells $37-53 \mu$ diameter

Chilo suppressalis

spherical cells predominant; few spindle-shaped cells

Mitsuhashi

(1967)

epithelial and fibroblast type cells

Varma and Pudney (1969)

cells epithelial in appearance 4-9 $\mu$ diameter and $12-20 \mu$ long

Schneider

A. aegypti

mononucleated and binucleated cells; loosely attached filamentous cells; vesicle-like bodies surrounded by layer Peleg and Shahar (1969) of epithelial-like cells

(To be continued) 
TABLE 2 (Continued)

Description of Cells from Continuous Insect Cell Lines

Cell Line

Reference

Culex quinquefasciatus (Say)

spindle-shaped cells $(21.5 \times 12.9 \mu)$ predominate; also round cells approx. $12.1 \mu$ diameter

Culiseta inornata and Aedes vexans

Trichoplusia ni

Carpocapsa pomonella

Samia cynthia round, spindle-shaped, and occasional fibroblast-like cells

round or oval cells possessing 1,2, or 3 protoplasmic extensions; approx. 1 per cent of cells are binucleate

spindle-shaped, round, or subspherical cells; ce!ls with single protoplasmic extension and polymorphic cells of irregular shapes

small round cells; occasionally elliptical, angular, or spindleshaped in older cultures
Hsu et al.

(1970)

Sweet and McHale (1970)

Hink

(1970)

Hink and Ellis (1971)

Chao and Ball (1971) 
it has on the properties of cells is uncertain, e.g. Suitor (1966) showed that Antheraea cells adapted to Antheraea perneyi hemolymph will support growth of Japanese encephalitis virus, but these same cells when adapted to Philosomio cynthia pryeri hemolymph could not be infected.

Since Singh's (1967) major breakthrough in establishing Aedes cells in hemolymph-free media, successful attempts have been reported in adapting Grace's A. eucalypti (Yunker et al., 1967; Nagle et al., 1967) and A. aegypti (Hsu et al.., 1967; Converse and Nagle, 1967; Nagle, 1969; Sohi, 1969) cell lines to hemolymph-free media. While elimination of the need for insect hemolymph is a notable advance in insect tissue culture, more information is required as to the changes that occur during the process of adaptation. Hsu et al. (1969) compared characteristics of a cloned subline of Grace's A. aegypti cell line before and after adaptation to hemolymph-free media and observed that cells adapted to $10 \%$ fetal bovine serum appeared somewhat smaller and attained a smaller number of cells at peak growth, but adapted cells retained approximately the same growth rate as the parent cells. Further studies along this line are definitely warranted.

\section{E. GROWTH OF ARBOVIRUSES IN ARTHROPOD TISSUE CULTURE}

\section{Primary Tick Tissue}

Rehacek and Pesek (1960) demonstrated that tissue explants from Dermacentor pictus and Ixodes ricinus would support growth of Eastern Equine 
Encephalitis (EEE) virus whereas a non-arbovirus, Newcastle Disease virus, would not propagate. Rehacek (1963) also found that Tick Borne Encephalitis (TBE) virus would multiply in primary tissue derived from $\underline{\mathrm{D}}$. marginatus and Hyalomma asiaticum.

Rehacek and Kozuch (1964) showed that $\underline{H}$. asiaticum tissue was extremely sensitive to low levels of TBE virus and could be used to detect quantities of virus so small that it failed to infect HeLa cells or suckling mice. These same authors (1969) subsequently successfully employed primary tick explants in field studies for the direct isolation of TBE virus from rodents blood and from infected ticks.

Rehacek $(1965 a+b)$ undertook an extensive survey and found that primary tick tissue from $\mathrm{H}$. asiaticum supported growth without cytopathic damage of 4 group A arboviruses (EEE, Western Equine Encephalitis, Semliki Forest, Sindbis) and 11 group B arboviruses including both tick (TBE, Louping III, Russian Spring-Summer Encephalitis, Langat) and mosquito borne (Japanese B Encephalitis, St. Louis Encephalitis, Powassan, Kyasanur Forest Disease, West Nile, Yellow Fever, Omsk Hemorrhagic Fever) arboviruses. All tick borne arboviruses multiplied well showing a 4 - $5 \log$ increase with the exception of Langat virus which gave only a $2-3 \log$ increase. VSV did not multiply nor did most of the non-arboviruses inoculated including EMC, polio, vaccinia, Newcastle Disease, and pseudorabies viruses. One exception, however, was LCM virus which was found to multiply readily in the tick tissue.

Yunker and Cory (1967) employed primary tissue cultures derived from 
D. andersoni and showed that this tissue readily supported sustained growth of Colorado Tick Fever virus. Rehacek et al. (1969) also demonstrated that Tribec virus will replicate in primary cultures from $\underline{H}$. dromedarii. Virus development was studied by fluorescent antibody staining and appeared to be restricted to the cytoplasm of infected cells.

\section{Antheraea eucalypti Cell Line}

In 1966 the first report of growth of an arbovirus in a continuous arthropod cell line was published by Suitor (1966) who showed that Japanese B Encephalitis virus was capable of growing in Grace's A. eucalypti cell line. This finding was followed by a publication by Converse and Nagle (1967) who reported that Yellow Fever virus was capable of at least surviving and probably of multiplying in A. eucalypti cells.

Yunker and Cory (1968) employed a subline of Antheraea cells adapted to grow in the absence of hemolymph to study the susceptibility of this cell line to a wide range of arboviruses. They observed that VSV as well as Yellow Fever, St. Louis Encephalitis, Japanese B Encephalitis, and Cache Valley viruses propagated to a high level (3.7 - 6.0 log increase) without cytopathic effect, whereas Bunyamwera, California Encephalitis, Snowshoe Hare, and Tahyna viruses appeared to give a very low level of infection of these cells. However, the majority of arboviruses inoculated apparently did not propagate. These included Chenuda, 
Chikungunya, Colorado Tick Fever, EEE, Itaqui, Junin, Langat, Marituba, Metucare, Modoc, Nyamanini, Phlebotomus Fever, Powassan, Quaranfil, Rio Bravo, Tacaribe, Turlock, and Western Equine Encephalitis viruses. Three nonarboviruses, Herpes Simplex, EMC, and pseudorabies viruses, also did not replicate in these cells.

Hann and Clarke (1971) attempted to infect Antheraea cells with Tacaribe and Junin viruses. No virus growth could be demonstrated although virus was found to persist for a longer period of time than in uninfected controls.

Yang et al. (1969) did an in depth study of growth of the Indiana serotype of VSV in A. eucalypti cells. Virus growth was determined by plaque assay in L cells, fluorescent antibody staining, and by electron microscopy. Virus was found to replicate quite readily in these cells with maximum titers of up to $10^{6}$ plaque forming units/ml but no cytopathic effect could be demonstrated. Fluorescent antibody staining indicated up to $50 \%$ infected cells at peak titers with infection apparently limited to the cell cytoplasm. Virus appeared to multiply equally well in the different morphological types of cells that comprise the Antheraea cell population and not to be restricted to only one or two morphological cell types. Virus maturation occurred primarily by budding at the plasma membrane.

\section{Primary Mosquito Tissue Culture}

Trager (1938) was the first to report on the use of primary mosquito tissue 
for infectivity studies with an arbovirus. Primary A. aegypti tissue infected with Western Equine Encephalitis virus was shown to sustain replication of virus with an increase of $10^{5}$ over the original inoculum.

This early work stood alone for many years until a report by Haines (1959) who attempted to demonstrate in vitro growth of Eastern Equine Encephalitis (EEE) virus in midgut cells obtained from A. aegypti larvae. Haines could not demonstrate virus growth although enhanced virus survival was noted.

Peleg and Trager $(1963 a+b)$ subsequently confirmed the potential for surviving mosquito tissue to support growth of arboviruses when they demonstrated significant growth of West Nile virus in cultures of imaginal discs from A. aegypti. Peleg (1968) also reported growth of EEE, Semliki Forest, and West Nile viruses in primary cultures prepared from embryonic cells of A. aegypti. Slight alterations were noted in cells infected with Semliki Forest and EEE viruses. No cytopathic effect (CPE) was observed in cells infected with West Nile virus. Peleg was able to detect a hemagglutinin in cultures infected with EEE virus but not in cultures infected with Semliki Forest or West Nile viruses.

Fujita et al. (1968) demonstrated growth of Japanese B Encephalitis virus without CPE in primary cultures derived from ovarian tissue of Culex molestus. Virus was successfully subcultured through a number of passages in Culex tissue. No difference in infectivity was noted between high and low mouse brain passaged material. Viral growth was detected by fluorescent antibody staining and appeared restricted to the cytoplasm of infected cells. 
Johnson (1969) infected primary larvae tissue derived from A. aegypti

and $\underline{A}$. triseriatus and was able to demonstrate growth of Venezuelan Equine Encephalitis (VEE) and EEE viruses in A. aegypti cells as well as growth of VEE in A. triseriatus. Growth of VEE in A. aegypti was influenced by the multiplicity of infection used, temperature of incubation of infected cells, agitation of cultures during growth, and $\mathrm{pH}$ of the culture medium. Johnson also reported some evidence to suggest the presence of a virus-inactivating factor in these larval tissue cultures. In a subsequent paper Johnson (1971) propagated VEE in primary tissue from minced $\underline{A}$. aegypti pupae. He found maximum infectivity titers attained in pupal tissue to be about tenfold less than in larval cultures and observed that an attenuated small plaque strain of VEE would not grow in pupal tissue although it was capable of propagating in larval tissue from the same species of insect. Virus passaged five times in pupal cells did not change in plaque size characteristics nor in virulence for mice.

\section{Continuous Mosquito Cell Lines}

Converse and Nagle (1967) were the first to report growth of an arbovirus in a continuous mosquito cell line when they showed that Yellow Fever virus was capable of replicating in the A. aegypti cell line established by Grace. Since then there have been many reports concerning growth of arboviruses in continuous mosquito cell lines. A complete review of the literature is presented in Table 4. A key to the arboviruses discussed is presented in Table 3. 
TABLE 3

Key to Arboviruses Discussed in Literature Review

\begin{tabular}{|c|c|c|}
\hline Abbreviations & Virus & Group \\
\hline ANO & Anopheles A & Anopheles A \\
\hline AHS & African Horse Sickness & African Horse Sickness \\
\hline ARK & Arkonam & ungrouped \\
\hline BAND & Bandia & Qalyub \\
\hline BEB & Bebaru & $A$ \\
\hline BWA & Bwamba & Bwamba \\
\hline BUN & Bunyamwera & Bunyamwera \\
\hline $\mathrm{CAL}$ & Calovo & Bunyamwera \\
\hline CE & California Encephalitis & California Encephalitis \\
\hline CEE & Central European Encephalitis & B \\
\hline $\mathrm{CHP}$ & Chandipura & Piry \\
\hline $\mathrm{CNU}$ & Chenuda & Kemerovo \\
\hline CHIK & Chikungunya & A \\
\hline CHIT & Chittoor (Batai) & Bunyamwera \\
\hline CR & Cowbone Ridge & B \\
\hline CTF & Colorado Tick Fever & ungrouped \\
\hline$C V$ & Cache Valley & Bunyamwera \\
\hline
\end{tabular}

(To be continued) 
TABLE 3 (Continued)

Key to Arboviruses Discussed in Literature Review

\begin{tabular}{lll} 
Abbreviations & \multicolumn{1}{c}{ Virus } & Group \\
C $_{5581}$ & unnamed; tick borne & ungrouped \\
DEN & Dengue & B \\
DHO & Dhori & ungrouped \\
EEE & Eastern Equine Encephalitis & A \\
EH & Edge Hill & B \\
FAR & Farallon & Hughes \\
GAN & Ganjam & ungrouped \\
ILE & Ilesha & BUN \\
ITQ & Itaqui & C \\
JA & Johnston Atoll & Quaranfil \\
JBE & Japanese B Encephalitis & B \\
JUN & Junin & Tacaribe \\
KEM & Kemerovo & Kemerovo \\
KFD & Kyasanur Forest Disease & B \\
KOK & Kokoberra & B \\
KSO & Kaisodi & Kaisodi \\
KUN & Kunjin & B \\
\hline
\end{tabular}

(To be continued) 
28.

TABLE 3 (Continued)

Key to Amboviruses Discussed in Literature Review

\begin{tabular}{|c|c|c|}
\hline Abbreviations & Virus & Group \\
\hline LGT & Langat & B \\
\hline LI & Louping III & B \\
\hline MAC & Machupo & Tacaribe \\
\hline MTB & Marituba & C \\
\hline MET & Metucare & ungrouped \\
\hline MIN & Minnal & ungrouped \\
\hline MOD & Modoc & B \\
\hline MVE & Murray Valley Encephalitis & B \\
\hline NYM & Nyamanini & ungrouped \\
\hline OMSK & Omsk Hemorrhagic Fever & B \\
\hline ONN & O'Nyong-Nyong & A \\
\hline PAL & Palyam & Palyam \\
\hline PHL & Phlebotomus Fever & Phlebotomus Fever \\
\hline PIR & Piry & Piry \\
\hline POW & Powassan & B \\
\hline QAL & Qalyub & Qalyub \\
\hline QRF & Quaranfil & Quaranfil \\
\hline
\end{tabular}

(To be continued) 
TABLE 3 (Continued)

Key to Arboviruses Discussed in Literature Review

\begin{tabular}{lll} 
Abbreviations & \multicolumn{1}{c}{ Virus } & Group \\
\cline { 2 - 3 } RB & Rio Bravo & B \\
RSSE & Russian Spring-Summer Encephalitis & B \\
SAG & Sagiyoma & A \\
SAT & Sathuperi & Simbu \\
SF & Semliki Forest & A \\
SFN & Naples Sandfly Fever & Phiebotomus Fever \\
SFS & Sicilian Sandfly Fever & Phlebotomus Fever \\
SH & Snowshoe Hare & California Encephalitis \\
SIL & Silverwater & Kaisodi \\
SIN & Sindbis & A \\
SLE & St. Louis Encephalitis & B \\
TAH & Tahyna & California Encephalitis \\
TBE & Tick Borne Encephalitis & B \\
TCR & Tacaribe & Tacaribe \\
TRB & Tribec & Kemerovo \\
TUR & Turlock & ungrouped \\
URB & unnamed; tick borne &
\end{tabular}

(To be continued) 
TABLE 3 (Continued)

Key to Arboviruses Discussed in Literature Review

\begin{tabular}{lll} 
Abbreviations & \multicolumn{1}{c}{ Virus } & Group \\
\hline VEE & Venezuelan Equine Encephalitis & A \\
VRC 15534 & unnamed; mosquito borne & Palyam \\
VRC 68886 & unnamed; mosquito borne & Palyam \\
VS & Vesicular Stomatitis & Vesicular Stomatitis \\
WAN & Wanowrie & ungrouped \\
WEE & Western Equirie Encephalitis & A \\
WN & West Nile & B \\
YF & Yellow Fever & B
\end{tabular}


TABLE 4

Growth of Arboviruses in Continuous Mosquito Cell Lines

Investigator

Mosquito Species

Comments

Converse and Nagle (1967)

Rehacek

(1968)

Filshie and Rehacek A. aegypti (Grace) (1968)
A. aegypti (Grace)

A.

Singh and Paul (1968b)
A. aegypti (Singh)

A. albopictus

Singh and Paul (1968a)

A. aegypti (Singh)

A. albopictus

Banerjee and Singh (1968)
A. albopictus
$2 \log$ increase of YF virus

growth and persistent infection by $M V E, J B E, W N$, and KUN; CPE caused by JBE. No growth of SIN, $B E B, K O K, S F$, or EH

EM study of MVE and JBE; numerous virus particles taken up by phagocytosis, particles in endoplasmic reticulum

growth of CHIK and WN. No growth of SIN, KFD, JBE, or DEN

growth of CHIK, SIN, JBE, WN, and DEN; CPE from WN, JBE, and DEN. No growth of KFD

growth of CHP. No growth of KFD, KSO, DHO, CHIT, GAN, SAT, EMC, polio, Coxsackie, or mouse-hepato-encephalomyelitis

growth of CHP, SAT, CHIT, GAN. No growth of KFD, KSO, DHO, polio, EMC, Coxsackie, or mousehepato-encephalomyelitis

persistent infection with CHIK, $J B E$, and $W N$. CPE from $W N$ and JBE 
TABLE 4 (Continued)

Growth of Arboviruses in Continuous Mosquito Cell Lines

\begin{tabular}{|c|c|c|}
\hline Investigator & Mosquito Species & Comments \\
\hline \multirow[t]{2}{*}{$\begin{array}{l}\text { Buckley } \\
\text { (1969) }\end{array}$} & A. aegypti (Singh) & $\begin{array}{l}\text { growth of CHIK, EEE, VEE, SF, } \\
\text { SLE, WN, YF, and VS. No growth } \\
\text { of BAND, CNU, CR, C } 5581, C T F \text {, } \\
\text { FAR, JA, LGT, MOD, QAL, SFN, } \\
\text { SFS, SIL, or URB }\end{array}$ \\
\hline & A. albopictus & $\begin{array}{l}\text { growth of CHIK, CTF, EEE, VEE, } \\
\text { SF, SLE, WN, YF, and VS; CPE } \\
\text { from WN. No growth of BAND, } \\
\text { CNU, CR, C5581, FAR, JA, LGT, } \\
\text { MOD, QAL, SFN, SFS, SIL, or } \\
\text { URB }\end{array}$ \\
\hline $\begin{array}{l}\text { Yunker and Cory } \\
\text { (1969) }\end{array}$ & A. albopictus & growth of tick borne CTF \\
\hline $\begin{array}{l}\text { Paul et al. } \\
\text { (1969) }\end{array}$ & A. albopictus & $\begin{array}{l}\text { description of polykaryotic CPE } \\
\text { caused by WN, JBE, and DEN }\end{array}$ \\
\hline $\begin{array}{l}\text { Banerjee and Singh } \\
\text { (1969) }\end{array}$ & A. albopictus & $\begin{array}{l}\text { CHIK from persistently infected } \\
\text { cells lost virulence for suckling } \\
\text { mice }\end{array}$ \\
\hline $\begin{array}{l}\text { Singh and Paul } \\
\text { (1969) }\end{array}$ & A. albopictus & $\begin{array}{l}\text { DEN isolated from human blood } \\
\text { and mosquitoes; identified by CF } \\
\text { from culture fluids }\end{array}$ \\
\hline $\begin{array}{l}\text { Pavri and Ghosh } \\
\text { (1969) }\end{array}$ & A. albopictus & $\begin{array}{l}\text { DEN } 1 \text { isolated from human blood; } \\
\text { identified by } C F\end{array}$ \\
\hline $\begin{array}{l}\text { Peleg } \\
\text { (1969b) }\end{array}$ & A. aegypti (Peleg) & $\begin{array}{l}\text { cells infected with RNA from SF } \\
\text { and WN but not with RNA from } \\
\text { EMC and polio viruses }\end{array}$ \\
\hline
\end{tabular}

(To be continued) 


\section{Growth of Arboviruses in Continuous Mosquito Cell Lines}

Investigator

Peleg

(1969a)

Suitor and Paul

(1969)

Suitor

(1969)

Mirchamsy et al. A. albopictus

(1970)

Dennett et al.

Bergold and Munz (1970)

Stevens

(1970)

Varma and Pudney (1971)

Buckley

$(1971 a+b)$

Singh

(1971)
Mosquito Species

A. aegypti (Peleg)

A. albopictus

A. albopictus

A. aegypti (Grace)

A. aegypti (Peleg)

+ A. albopictus

A. albopictus

Anopheles stephensi

+ A. aegypti (Varma and Pudney)

Anophe les stephensi, A. aegypti (Singh), †. albopictus

A. aegypti (Singh)
Comments

cells persistently infected with SF; small proportion of infected cells

synctial formation from DEN 2; CPE enhanced on plastic

plaques produced by JBE

growth and persistent infection by $A H S$; no CPE

comparative growth of KUN in mosquito and vertebrate cells

growth of PIR in both cell lines;

EM study in A. albopictus

replication of DEN and SIN in spinner culture; chronic infection by SIN; no effect with actinomycin

growth of ANO A, BWA, BUN, and ONN in Anopheles but not in Aedes cells

growth of CHIK in all lines; growth of ONN in all except $A$. aegypti

review of previous work

(To be continued) 


\section{Growth of Arboviruses in Continuous Mosquito Cell Lines}

\begin{tabular}{|c|c|c|}
\hline Investigator & Mosquito Species & Comments \\
\hline $\begin{array}{l}\text { Singh } \\
\text { (1971) }\end{array}$ & A. albopictus & $\begin{array}{l}\text { extension of previous reports - } \\
\text { growth of PAL, VRC 15534, } \\
\text { VRC 68886, MIN, ARK. No } \\
\text { growth of WAN }\end{array}$ \\
\hline $\begin{array}{l}\text { Whitney and Deibel } \\
\text { (1971) }\end{array}$ & $\begin{array}{l}\text { A. aegypti (Singh) } \\
+ \text { A. albopictus }\end{array}$ & $\begin{array}{l}\text { growth and persistent infection by } \\
C E_{\text {; }} \text { small number of infected cells }\end{array}$ \\
\hline $\begin{array}{l}\text { Hsu } \\
(1971)\end{array}$ & $\frac{\text { Culex quinquefasciatus }}{\text { (Say) }}$ & $\begin{array}{l}\text { growth of SAG, JBE, MVE, WN, } \\
\text { BUN, DEN; no CPE. No growth } \\
\text { of EEE or SIN }\end{array}$ \\
\hline $\begin{array}{l}\text { Libikova and Buckley } \\
\text { (1971) }\end{array}$ & $\begin{array}{l}\text { A. aegypti (Singh) } \\
\text { +A. albopictus }\end{array}$ & $\begin{array}{l}\text { growth of KEM. Persistent infection } \\
\text { of A. albopictus; cytoplasmic mat- } \\
\text { uration; small per cent infected } \\
\text { cells }\end{array}$ \\
\hline $\begin{array}{l}\text { Singh et al. } \\
(1971)\end{array}$ & A. albopictus & $\begin{array}{l}\text { cells adapted to calf and goat sera; } \\
\text { change in susceptibility to JBE but } \\
\text { not to CHIK }\end{array}$ \\
\hline $\begin{array}{l}\text { Sweet and Unthank } \\
\text { (1971) }\end{array}$ & 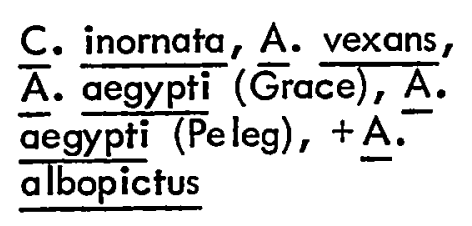 & $\begin{array}{l}\text { growth of SLE and JBE. No growth } \\
\text { of } C E, C V \text {, or EEE. Comparison of } \\
\text { arbovirus growth in different cell } \\
\text { lines }\end{array}$ \\
\hline $\begin{array}{l}\text { Rehacek et al. } \\
\text { (1971) }\end{array}$ & A. albopictus & $\begin{array}{l}\text { failure to cultivate Friend leukemia, } \\
\text { murine sarcoma and reticuloendo- } \\
\text { theliosis viruses }\end{array}$ \\
\hline $\begin{array}{l}\text { Peleg } \\
\text { (1971) }\end{array}$ & A. aegypti (Peleg) & $\begin{array}{l}\text { persistent infection by SF, WN, and } \\
\text { JB. Attenuation of SF for adult } \\
\text { mice and hamsters; immunizing } \\
\text { capability }\end{array}$ \\
\hline
\end{tabular}

(To be continued) 
TABLE 4 (Continued)

Growth of Arboviruses in Continuous Mosquito Cell Lines

$\underline{\text { Investigator }}$

Kelly and Dalgarno (i971)

Stollar et al. (1972)

Lyons and Heyduk (1972)

Cory and Yunker (1972)

Peleg

(1972)

Shortridge et al. (1972)
A. aegypti (Peleg)

Mosquito Species

A. aegypti (Grace), A. aegypti (Peleg), + A. albopictus

A. albopictus

A. albopictus

A. albopictus

A. aegy'pti (Varma and Pudney)
Comments

biochemical studies on replication of KUN and SF

study of different species of RNA produced during SIN replication

comparative growth of $\mathrm{CE}$ in mosquito and vertebrate cells; persistent infection

plaques at $37^{\circ} \mathrm{C}$ from $\mathrm{VS}, \mathrm{WN}$, $J B E, Y F$, and DEN. No plaques from POW, KEM, SLE, or ITQ

EEE infected up to $50 \%$ of cells; dual infection with EEE and SF but apparently in different cells

cells found to produce levels of adenovirus components comparable to He La cells; only intracellular antigens produced 
Most studies have shown a good correlation between use of mosquito cell lines and ability of only mosquito borne arboviruses to multiply in these cell lines (although not all mosquito borne arboviruses are able to replicate in currently available mosquito cell lines). The first exception to this rule, however, was published by Buckley (1969) and by Yunker and Cory (1969) who reported that Colorado Tick Fever virus will multiply in Singh's A. albopictus cell line. Libikova and Buckley (1971) subsequently showed that another tick borne arbovirus, Kemerovo virus, will replicate in A. aegypti (Singh) and A. albopictus cell lines.

Studies reported by Singh and Paul (1968a), Peleg (1969b), and by Rehacek et al. (1971) indicated that non-arboviruses could not replicate in any of the mosquito cell lines. Recently, however, an exception has been found to this generalization. Shortridge et al. (1972) reported limited growth of an adenovirus in a continuous cell line from $\underline{A}_{0}$ aegypti (Varma and Pudney). An abortive type of infection was found to occur in which no infective virus was released from the mosquito cells but the cells were found to produce levels of adenovirus components comparable to HeLa cells. Intracellular antigens produced were detected by complement fixation tests. On the basis of these results the authors suggested that earlier reports of inability of non-arboviruses to multiply in mosquito cell lines should be re-evaluated.

One well documented observation is the ability of arboviruses to set up a long term persistent infection of mosquito cell lines. Rehacek (1968) showed that A. aegypti (Grace) cells infected with Murray Valley Encephalitis, Japanese B 
Encephalitis (JBE), West Nile (WN), and Kunjin viruses became persistently infected. Banerjee and Singh (1968) reported establishment of carrier cultures from A. albopictus cells infected with JBE, WN, and Chikungunya viruses. Although CPE resulted from infection of $A$. albopictus with JBE and WN, many cells remained on the glass and multiplied to set up the persistent infection.

Peleg (1969a) did a careful study of Semliki Forest infected A. aegypti (Peleg) cells and reported a long term inapparent infection with only a small proportion of the cell population infected. Peleg was unable to demonstrate antiviral substances in his culture medium nor could he find evidence for any interferon-like substances which might play a role in maintaining the virus-cell equilibrium.

Similar examples of persisfent infection have been reported by Mirchamsy ef al. (1970), Stevens (1970), Whitney and Deibel (1971), Libikova and Buckley (1971), Peleg (1971), and by Lyons and Heyduk (1972). Persistent infection of mosquito cell lines always tends to involve only a tiny fraction of the cell population and infected cultures show no apparent change in morphology or in growth rate. Banerjee and Singh (1969) and Peleg (1971) have reported instances where arboviruses produced by persistently infected cells have lost virulence for one or more vertebrate hosts. Gross CPE of infected mosquito cells is rare but has been reported for A. albopictus cells infected with a few group B mosquito borne arboviruses. Paul et al. (1969) summarized the main features of polykaryocytic CPE occurring in cells infected with WN, JBE, and Dengue (DEN) viruses as (i) cytolysis of individual small cells, (ii) development of large syncytial masses, (iii) gradual increase in number of multi- 
nucleated giant cells, (iv) active phagocytosis of dead and dying cells, and (v) an ultimate recovery of cell population in infected cultures. Suitor and Paul (1969) noted that the CPE produced by DEN virus was much enhanced when cells were grown on plastic rather than on glass surfaces.

Suitor (1969) was able to utilize the fact that JBE produces CPE in A. albopictus to work out c plaquing method for this virus-cell system. More recently Cory and Yunker (1972) were able to demonstrate plaques in A. albopictus infected with a number of arboviruses. Plaques were produced after incubation of infected cells at $37^{\circ} \mathrm{C}$.

One possible explanation for the lack of gross CPE in arbovirus infected mosquito cells is the fact that often only a fraction of the mosquito cells are infected. However, there may be more factors involved. For example Jenkin et al. (1971) compared membrane composition of $\underline{A}$. aegypti and monkey kidney $(\mathrm{MK}-2)$ cells and observed the presence of plasmalogen in phospholipids of $M K-2$ cells but no plasmalogens could be found in A. aegypti. Since phospholipids play an important role in membrane structure, the authors speculate that plasmalogen present in mammalian cells may be utilized during virus infection and play a role in cell lysis. This could not happen in A. aegypti cells since they lack plasmalogens.

Studies have been reported concerning the suitability of using the A. albopictus cell line for primary isolations of DEN virus from human sera and mosquitoes (Singh and Paul, 1969; Pavri and Ghosh, 1969). These studies were successful, i.e. DEN was isolated directly from blood and mosquitoes and identified by 
complement fixation from cell culture fluids. Yunker (1971) quoted unpublished reports that mosquito cell cultures have been successfully used in isolating and identifying DEN viruses from human sera or mosquitoes during outbreaks in the Philippines and Puerto Rico.

\section{Drosophila melanogaster Cell Line}

Hannoun and Echalier (1971) recently reported preliminary results of studies concerning growth of several arboviruses in established cell lines from Drosophila.

They found that group A arboviruses (Chikungunya and Sindb is (SIN)) multiplied rapidly and to high titers. However, of the group B arboviruses inoculated, only WN grew well while St. Louis Encephalitis, DEN 1, 2, and 3, JBE, and Central European Encephalitis viruses multiplied to low titers and DEN 4 and Yellow Fever did not grow at all. Also Tahyna (TAH) virus of the California Encephalitis group of viruses was found to replicate while Ilesha and Sicilian Sandfly Fever viruses did not multiply.

Cytopathic effect was not observed in any of the infected cell cultures, and carrier cultures were established in Drosophila cells infected with DEN 2, TAH, and SIN viruses. 


\section{MATERIALS AND METHODS}

\section{A. MEDIA}

Media were obtained from commercial sources as powders or tablets which were dissolved in double distilled water according to the accompanying instructions. Sterilization of media was carried out by filtration through millipore membranes

of $0.22 \mu$ pore size. Antibiotics used were Gentamicin sulfate (Schering Corp.) added to give a final concentration of $15 \mu \mathrm{g}$ per $\mathrm{ml}$ of medium and Mycostatin (Gibco) added to give a final concentration of 10 units per $\mathrm{ml}$ of medium.

Details of the contents and methods of preparation of all media and reagents are presented in the Appendix.

\section{B. PREPARATION OF VIRUS POOLS}

\section{Cocal Virus}

Cocal virus strain TRVL 40233 was obtained at mouse brain passage 1 from the Trinidad Regional Virus Laboratory. Virus material, reconstituted in Maintenance Medium (MM) No. 3 (see Appendix), was inoculated onto confluent monolayers of BHK-21 cells. MM No. 3 was added and the monolayers were incubated at $37^{\circ} \mathrm{C}$. After $48 \mathrm{hr}$, when CPE was evident, the fluid was removed and centrifuged for $10 \mathrm{~min}$ at $4^{\circ} \mathrm{C}$ in an International Clinical Centrifuge at approx. $1470 \times \mathrm{g}$ to remove cellular 
debris. Gamma globulin (GG) free calf serum was added to the supernatant to a final concentration of $10 \%$ and the virus suspension was dispensed into sterile $12 \times 75 \mathrm{~mm}$ plastic tubes (Falcon Plastics) and stored in a Revco freezer at $-70^{\circ} \mathrm{C}$.

All Cocal virus used in subsequent studies were grown up in primary chick embryo monolayers seeded from this pool of stock virus, prepared and stored as just described. A chick embryo grown pool of Cocal virus yielded approx. $1-3 \times 10^{8}$ plaque forming units (p.f.u.) per $\mathrm{ml}$.

For certain experiments, a concentrated pool of virus was required. This was prepared by seeding chick embryo monolayers as per usual. Supernatant containing virus was spun for $10 \mathrm{~min}$ at approx. $1470 \times \mathrm{g}$, and virus was then pelleted by spinning in an IEC Model B-60 ultracentrifuge at $41,000 \times \mathrm{g}$ (fixed angle head rotor No. 496, 22,000 r.p.m.) for $2 \mathrm{hr}$ at $4^{\circ} \mathrm{C}$. Pelleted virus was resuspended in tenfold less MM No. 3 containing $10 \%$ GG free calf serum and stored at $-70^{\circ} \mathrm{C}$.

\section{Mayaro Virus}

Mayaro virus strain TRVL 4070 at mouse brain passage 160 was used to seed a 16 oz medicine bottle of BHK-21 cells. After $48 \mathrm{hr}$, when advanced CPE was evident, virus was harvested and stored at $-70^{\circ} \mathrm{C}$ as described in B. 1 .

\section{Nepuyo Virus}

Nepuyo virus strain TRVL 18462 (run \#139) dessicated material was re- 
constituted and passaged by intracerebral (i.c.) inoculation in suckling mouse brain. Virus thus harvested was used to seed a $16 \mathrm{oz}$ medicine bottle of BHK-21 cells. After 5 days, when $\mathrm{CPE}$ was most evident, virus was harvested and stored at $-70^{\circ} \mathrm{C}$ as described in B.1.

\section{Flanders-Hart Park Virus}

Flanders-Hart Park virus strain R 11987 was obtained as suckling mouse brain passage 2 from Dr. Karabatsos of the Yale Arbovirus Research Unit. Reconstituted virus was inoculated i.c. into 3 day old suckling mice. Virus was harvested after 3 days from sick mice making a $20 \%$ mouse brain suspension in MM No. 3 containing $10 \% \mathrm{GG}$ free serum. The virus containing suspension was centrifuged for $10 \mathrm{~min}$ at $4^{\circ} \mathrm{C}$ at approx. $1470 \times \mathrm{g}$ to remove cellular debris and virus containing supernate was stored at $-70^{\circ} \mathrm{C}$.

\section{PREPARATION OF TISSUE CULTURE MONOLAYERS}

\section{BHK-21 Cells}

The BHK-21 continuous line of baby hamster kidney cells was grown at $37^{\circ} \mathrm{C}$ in 16 oz medicine bottles on a medium consisting of BHK-21 medium supplemented with tryptose phosphate broth and calf serum (see Appendix). Confluent monolayers, obtained after 3 days growth, were detached from the glass by trypsin 
43.

and subcultured to new 16 oz bottles to maintain stock cultures.

\section{2. $\underline{L}$ Cells}

The mouse $\mathrm{L}$ cell line, clone 929 , was propagated at $37^{\circ} \mathrm{C}$ in a similar manner using a growth medium consisting of minimum essential medium (Eagle's) and supplements (see Appendix).

\section{Chick Embryo Cells}

Primary chick embryo monolayers were prepared by a modification of the methods of McClain and Hackett (1958) and Cooper (1967). Nine to eleven day old embryos were placed in a sterile Petri plate and the heads, feet, and viscera removed. The remaining tissue was minced with scissors, washed twice with saline, and forced through a $30 \mathrm{ml}$ syringe without a needle into an Erlenmeyer flask. Equal volumes of saline and $0.25 \%$ trypsin solution were added to a final volume of approx. $20 \mathrm{ml}$ per embryo. A sterile magnet was added and the suspension was agitated at room temperature for $30 \mathrm{~min}$.

Trypsinized cells were decanted through several layers of gauze into centrifuge tubes which were then spun in an International Universal Centrifuge at $270 \times \mathrm{g}$ for $10 \mathrm{~min}$. The supernatant was discarded and the cells, washed once in chick embryo growth medium (see Appendix), were suspended in the same growth medium using approx. $25 \mathrm{ml}$ medium per embryo. 
Suspended cells were counted in a bright-line haemocytometer (American Optical Co.) using equal volumes of the suspension and $0.2 \%$ Trypan Blue solution in Hanks BSS (see Appendix). The cell count was adjusted to approx. $2-4 \times 10^{6}$ cells per $\mathrm{ml}$, and disposable plastic Petri plates (Falcon Plastics), $60 \mathrm{~mm}$ in diameter, were seeded with $5 \mathrm{ml}$ per plate of the suspension. Incubation was carried out at $37^{\circ} \mathrm{C}$ in a humidified incubator with an atmosphere of $5 \% \mathrm{CO}_{2}$. Confluent monolayers were obtained in 24 to $48 \mathrm{hr}$.

\section{A. albopictus Cells}

The A. albopictus cell line (Singh, 1967) was obtained from Dr. Buckley in passage 156. Stock cultures of cells were grown and stored in liquid nitrogen at passage 160 to serve as a continuous supply of cells. With the exception of persistently infected cells, all cultures were discarded from experimental use at passage 180 and new ampoules of cells were removed from liquid nitrogen.

Cell stocks were grown at $30^{\circ} \mathrm{C}$ in $16 \mathrm{oz}$ medicine bottles containing Mitsuhashi-Maramorosch culture medium MM 80-20 (see Appendix). Confluent monolayers, obtained approx. 5 days after a 1:10 split, were detached from the glass by trypsin and subcultured to new 16 oz bottles.

\section{A. aegypti Cells}

The A. aegypti cell line (Singh, 1967) was received from Dr. Buckley in 
passage 53. Stocks of cells were grown and stored in liquid nitrogen at passage 56. With the exception of persistently infected cells, all cultures were discarded from experimental use at passage 70 and new ampoules of cells were removed from liquid nitrogen.

Cell stocks were grown at $30^{\circ} \mathrm{C}$ in 16 oz medicine bottles containing MM 80-20. Confluent monolayers, obtained approx. 7 days after a 1:3 split, were detached from the glass by pronase (see Appendix) and subcultured to new 16 oz bottles.

\section{EXPERIMENTAL ANIMALS}

Swiss white mice were supplied by Robidoux Laboratory Animals, Montreal, as $1-4$ day old litters or as 2 month old males.

New Zealand white rabbits of average weight $2.5 \mathrm{~kg}$ were also supplied by Robidoux Laboratory Animals. Guinea pigs of average weight $500 \mathrm{~g}$ were supplied by Canadian Breeding Farm, Laprairie. These two latter animals were used for the production of antiserum.

\section{E. ANIMAL INOCULATIONS}

1. Antiserum Production

Rabbits were used for the production of Cocal immune serum. The vaccine was prepared as described in Section B.1. for preparation of concentrated virus pool. 
Immunization was done by a multiple sittes method*. Rabbits were inoculated subcutaneously in seven different sites near regional lymph nodes with $0.4 \mathrm{ml}$ per site of vaccine mixed with equal volume of Freund's complete adjuvant (see Appendix). All four foot pads were also injected each with $0.2 \mathrm{ml}$ of a mixture of virus and Freund's incomplete adjuvant. No booster dose was required and rabbits were bled after 3 - 4 weeks. The serum was collected after overnight clotting of the blood at $4^{\circ} \mathrm{C}$ and stored at $-20^{\circ} \mathrm{C}$.

Guinea pigs were used for the production of Cocal immune serum and for the production of Mayaro immune serum. Vaccines used were Cocal concentrated pool (see Section B. 1.) and Mayaro stock pool (see Section B.2.). Guinea pigs were inoculated intramuscularly in each hind leg with a total of $1.0 \mathrm{ml}$ mixture of virus and Freund's complete adjuvant. A booster dose was administered in similar fashion after 2 weeks, and guinea pigs were bled after 4 weeks. Serum was separated from whole blood and stored at $-20^{\circ} \mathrm{C}$.

\section{Experimental Inoculations}

Intracerebral inoculations were performed on suckling and adult mice, the volumes given being $0.02 \mathrm{ml}$ per mouse for the former and $0.03 \mathrm{ml}$ per mouse for the latter. The inocula consisted of varying dilutions of test virus in phosphate buffered

* Dr. R. Siboo, Department of Microbiology and Immunology, Mc Gill University; personal communication. 
saline. Adult mice were anaesthetized with ether prior to inoculation.

\section{F. TITRATION OF VIRUS BY PLAQUE ASSAY}

The plaque assay method, developed originally by Dulbecco (1952) and modified by Dulbecco and Vogt (1954) and Cooper (1967) was used for titration of virus suspensions. Confluent chick embryo monolayers in Petri plates (Section C.3.) were washed twice with saline and inoculated with $0.1 \mathrm{ml}$ per plate of tenfold dilutions of virus made in phosphate buffered saline. Dilutions were plated in duplicate, and plates were incubated at $37^{\circ} \mathrm{C}$ for $1 \mathrm{hr}$ to allow virus adsorption to occur. Petri plates were rotated after $30 \mathrm{~min}$ to redistribute the inoculum and at the end of the incubation period $5.0 \mathrm{ml}$ of overlay medium (see Appendix) was added to each plate. The overlay was allowed to gel and plates were returned to the $37^{\circ} \mathrm{C}$ humidified incubator with an atmosphere of $5 \% \mathrm{CO}_{2}$. During these manipulations, the virus was exposed to bright light for as brief a time as possible, to minimize inactivation of infectivity and reduction of titer which might have occurred due to light sensitivity of Cocal virus (Thormar, 1967).

After $48 \mathrm{hr}$ incubation, $2.5 \mathrm{ml}$ of a 1/10,000 solution of Neutral Red (see Appendix) were added to each plate and left for $4 \mathrm{hr}$ at $37^{\circ} \mathrm{C}$. Plaques were then readily countable. The average number of plaques per plate multiplied by the dilution factor was used to calculate the titer of the inoculum. Titers were expressed in plaque forming units (p.f.u.) per $\mathrm{ml}$. 


\section{G. PLAQUE NEUTRALIZATION TEST}

Varying dilutions of serum were made in phosphate buffered saline and mixed with equal volumes of a virus suspension diluted to give 20 to 30 plaques per plate. These mixtures were allowed to stand at room temperature for $30 \mathrm{~min}$. Volumes of $0.2 \mathrm{ml}$ of each virus/serum mixture were then plated in duplicate on washed chick embryo monolayers and the plaque technique carried out as described in Section $F$. Normal serum and virus controls were included.

The results from antibody titrations were expressed as per cent reduction of plaques of the test virus suspension by various dilutions of test serum.

\section{H. INFECTION AND SAMPLING OF CELL CULTURES}

\section{Infection of Monolayers}

Cell cultures to be infected were grown in 2 oz medicine bottles. Cells from one confluent monolayer were scraped off the glass with a rubber policeman, suspended in equal volumes of Trypan Blue (see Appendix), and counted in a hemocytometer to estimate the number of cells per bottle in order to infect with the desired input multiplicity.

Confluent monolayers were then washed 2 times with PBS and $0.1 \mathrm{ml}$ of virus diluted in PBS was added to each monolayer. Virus adsorption was allowed to proceed for $1 \mathrm{hr}$ at $30^{\circ} \mathrm{C}$ at which time all unadsorbed virus was neutralized by $30 \mathrm{~min}$ 
exposure at room temperature to Cocal immune serum diluted in mosquito maintenance medivin MM 97-3 (see Appendix).

Monolayers were then washed 5 times with $1 \mathrm{ml}$ PBS per wash, $5 \mathrm{ml}$ MM 97-3 were added to each bottle, and bottles were incubated at the desired temperature.

\section{Sampling Procedure}

All sampling was done with material pooled from duplicate bottles.
a) Extracellular Virus

Extracellular virus sampling was performed by removing MM 97-3 from infected cells and titrating by plaque assay on confluent chick embryo monolayers as described in Section F. Prior to titrating, all samples were quick frozen in a dry ice-ethanol mixture and stored at $-70^{\circ} \mathrm{C}$ in duplicate tubes to avoid decrease in titers which accompanied repeated freezing and thawing in cases where virus assays had to be repeated.

b) Cell Associated Virus

Prior to sampling for cell associated virus (CAV), Cocal immune serum, diluted in MM 97-3, was added to each bottle at room temperature for $30 \mathrm{~min}$ to 
neutralize all extracellular virus. Monolayers were then washed 5 times with sterile PBS. Infected monolayers were removed into $1 \mathrm{ml}$ fresh MM 97-3 by a combination of trypsin treatment and scraping off remaining cells with a rubber policeman. Viable cell counts were performed using Trypan Blue, and cells were quick frozen and stored in duplicate at $-70^{\circ} \mathrm{C}$ until samples were titrated. Preliminary studies revealed virtually $100 \%$ lysis of all cell lines after only one freeze thaw cycle.

\section{c) Assay for Infective Centers}

Infected monolayers were treated as for CAV sampling. However, immediately subsequent to removal from the glass surface, a known quantity of cells was added directly to confluent chick embryo monolayers and plaque assay was performed as per usual (Section F.) except that plates were not rotated after $30 \mathrm{~min}$ adsorption to avoid possible spread of virus released from infected cells. For calculation of per cent infected cells, each plaque was assumed to represent one infected cell (Maguire and Miles, 1965; Peleg, 1969).

\section{ELECTRON MICROSCOPY}

Cells to be examined were either processed as per CAV (Section $\mathrm{H}$ ) with one aliquot used for virus titration and one aliquot used for electron microscopic studies or, in other instances, supernatant was simply drained off sister bottles of infected cultures and cells were gently scraped from the glass into fresh MM 97-3. 
Cells were pelleted by centrifugation for $10 \mathrm{~min}$ in an International Clinical Centrifuge at approx. $1470 \times \mathrm{g}$ and the supernate discarded. Cells were then prepared for electron microscopic examination by the cell spread or thin section technique.

\section{Cell Spread Technique}

A portion of the dry pellet was taken up in a Pasteur pipette and placed onto the surface of a droplet of sterile distilled water on a piece of Parafilm. Cells were thus ruptured by osmotic shock (osmolysis) and released virus particles were taken up onto a formvar coated grid touched to the surface of the drop. Virus was stained with $2 \%$ phosphotungstic acid (see Appendix).

\section{Thin Sectioning Technique}

Cells were fixed at $4^{\circ} \mathrm{C}$ for $1 \mathrm{hr}$ in $2 \%$ glutaraldehyde (see Appendix). Cell pellets were washed 3 times and resuspended in $0.1 \mathrm{M}$ Sorenson's phosphate buffer before post fixation in $2 \%$ osmium tetroxide containing sucrose (see Appendix) for $2 \mathrm{hr}$. The pellets were cut into approx. $1 \mathrm{~mm}$ cubes, stained in saturated uranyl acetate for $1 \mathrm{hr}$ and dehydrated through a graded series of alcohol solutions $(30 \%$, $50 \%, 70 \%, 90 \%$, and $100 \%)$. Tissue blocks were then placed in Spurr embedding medium (Polysciences lnc.), a low viscosity embedding medium of a composition as described in the Appendix (Spurr, 1969). After $5 \mathrm{hr}$, blocks were removed and placed in flat embedding molds to which was added fresh Spurr and blocks were incubated at 
$70^{\circ} \mathrm{C}$ for $24 \mathrm{hr}$.

Following the polymerization period the Spurr blocks were trimmed and sectioned on an LKB ultratome using glass knives. Sections were collected on clean uncoated copper grids, dried, stained with $0.1 \%$ lead acetate for $30-45$ sec, washed with distilled water, dried again and examined in a Philips 300 electron microscope.

\section{J. GENERAL PLAN OF THE EXPERIMENTS}

In this section an outline of the experimental procedures will be given and the details peculiar to each experiment will be stated in Section IV.

The experiments fall into four general categories: 1) characterization of growth of Cocal in different cell lines, 2) efforts to increase virus titers in mosquitc cells for electron microscopic studies, 3) studies on persistent infection of mosquito cells, and 4) experiments to understand the nature of resistance of $A$. albopictus cells to Cocal virus.

\section{Growth of Cocal in Different Cell Lines}

Comparisons were made in rate of adsorption and growth of Cocal virus in mouse $L$ cells and in 2 mosquito cell lines - $\underline{A}$. albopictus and A. aegypti. Susceptibility of these cell lines to different input multiplicities of virus was determined. 
2. Efforts to Increase Virus Titers in Mosquito Cells

Initial attempts to demonstrate virus growth in mosquito cells by electron microscopy met with failure due presumably to the low titer of virus produced during infection. Efforts were made to increase titer of infected cells by various procedures including use of $0.1 \%$ DEAE dextran (see Appendix) in the virus diluent during adsorption of virus to mosquito cells, incubation of infected cells at an elevated temperature $\left(37^{\circ} \mathrm{C}\right)$, and by studying the effect of different serum concentrations on subsequent virus titers.

Successful attempts to increase virus titer allowed a limited electron microscopic study of Cocal virus replication in $\underline{A}$. albopictus.

\section{Studies on Persistent Infection of Mosquito Cells}

Cell cultures were persistently infected with Cocal virus and the course of virus infection in both $\underline{A}$. albopictus and $\underline{A}$. aegypti cell lines was followed through 60 passages including 10 successive passages under immune serum. The growth rate of infected cells was compared with that of uninfected controls. Characteristics of small plaque variants produced in persistently infected cells were compared with those of normal plaque Cocal virus.

4. Nature of Resistance of A. albopictus to Cocal Virus

The nature of resistance of $A$. albopictus to Cocal virus was studied by 
attempting to better define the effect of increased temperature $\left(37^{\circ} \mathrm{C}\right)$ on elevation of virus titer in A. albopictus, by superinfection of persistently infected cells with Cocal and unrelated arboviruses, by testing mosquito medium for antiviral factors, by assays for possible production of interferon by mosquito cells, and by the use of inhibitors (actinomycin D and puromycin). 
55.

\section{EXPERIMENTAL RESULTS}

\section{A. PRELIMINARY EXPERIMENTS}

\section{Arbovirus Check of Mosquito Cell Lines}

Cells from stock cultures of $\underline{A}$. aegypti and $\underline{A}$. albopictus were lysed by one freeze thaw cycle and inoculated intracerebrally into suckling mice (Section III.E.). All mice survived indicating that the mosquito cells were not contaminated with any arbovirus capable of killing suckling mice.

\section{Mycoplasma Check of Mosquito Cell Lines}

Cells from A. aegypti and $\underline{A}$. albopictus stock cultures were lysed by ultrasonication and inoculated into Mycoplasma growth medium consisting of one part PPLO Agar (Difco) and one part PPLO Broth (Difco). No Mycoplasma was detected after four weeks incubation.

\section{Antibody Titers of Immunized Animals}

The antisera were prepared as described in Section III. E. and titrated by the plaque neutralization method (Section III.G.). Antiserum dilutions of $1 / 10$ to $1 / 8000$ were incubated for $30 \mathrm{~min}$ at room temperature with equal volumes of the 
challenge virus suspension diluted to give approx. 25 plaques per plate. Eighty per cent plaque reduction of Cocal virus occurred at $1 / 2000$ to $1 / 4000$ dilutions of sera prepared in rabbits and at $1 / 4000$ dilution of sera prepared in guinea pigs. Eighty per cent plaque reduction of Mayaro virus occurred at a $1 / 500$ dilution of antisera prepared in guinea pigs.

\section{B. GROWTH OF COCAL IN DIFFERENT CELL LINES}

\section{Adsorption of Virus to Mosquito and L Cells}

As a pre liminary to growth studies, the rate of adsorption of Cocal virus to mosquito and $L$ cells was compared. The procedure for infecting cell monolayers and for subsequent assay for infective centers is described in Section III.H. Infective center assays were not performed for $\underline{A}$. aegypti as cells could not be completely separated by trypsin or pronase treatment as required for a proper assay. Results from studies of adsorption of virus to A. albopictus and $\mathrm{L}$ cells at $30^{\circ} \mathrm{C}$ using an input multiplicity of 0.1 are presented in Table 5.

It can be seen that only a minute fraction of the $A$. albopictus cell population are infected under these conditions (always less than $0.008 \%$ of cells) whereas approx. $5 \%$ of the mouse $L$ cells are infected under comparable conditions. 
TABLE 5

Adsorption of Cocal Virus to $\mathrm{A}$. albopictus and $\mathrm{L}$ Cells at $30^{\circ} \mathrm{C}$

with an Input Multiplicity of 0.1 .

\begin{tabular}{c|c|c|c|c|}
\hline \multirow{2}{*}{$\begin{array}{c}\text { Time of } \\
\text { Adsorption } \\
(\mathrm{min})\end{array}$} & \multicolumn{2}{|c|}{ A. albopictus } & \multicolumn{2}{|c|}{ L Cells } \\
\cline { 2 - 5 } & 1 & 2 & 1 & 2 \\
\hline \multirow{2}{*}{5} & $0.0014^{*}$ & 0.0003 & 0.67 & 1.36 \\
15 & 0.0027 & - & 0.88 & 6.30 \\
30 & 0.0037 & 0.0045 & 1.53 & 5.36 \\
60 & 0.0008 & 0.0032 & 3.47 & 5.36 \\
120 & 0.0075 & 0.0048 & 2.40 & 9.78 \\
\hline
\end{tabular}

* Resuitis expriessed as per cent infected cells.

2. Growth of Cocal in Mosquito and L Cells

a) L Cells

$L$ cells were infected with Cocal virus at an input multiplicity of 10 and incubared at $30^{\circ} \mathrm{C}$. At various intervals during the growth cycle, cells were harvested and assayed for virus released, cell associated virus (CAV), and per cent infected cells as described in Section III.H. The results are presented in Fig. 1. It may be 
Fig. 1. Growth of Cocal virus in L cells at $30^{\circ} \mathrm{C}$ with an input multiplicity of 10 .

$\longrightarrow$ Extracellular virus

$\bullet--\rightarrow$ Cell associated virus 
58.

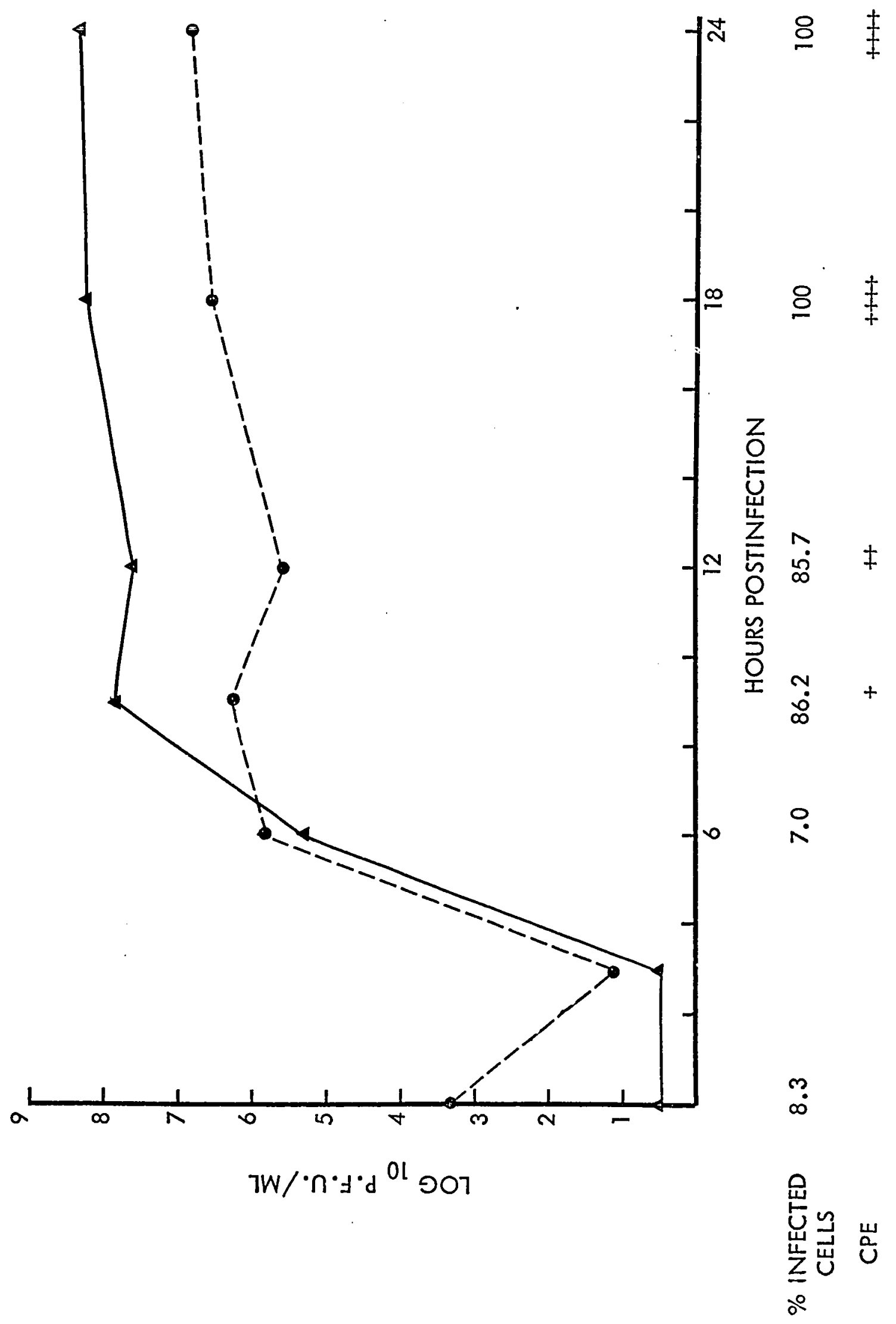


seen that little or no virus had been released from infected cells for up to $6 \mathrm{hr}$ postinfection with the number of infected cells remaining at about $7 \%$. However, by $9 \mathrm{hr}$ postinfection large quantities of virus have been released and spread to surrounding cells and approx. $86 \%$ of the cell population were infected. Initial signs of cytopathic effects (CPE) were observable at this stage. Cytolytic infection progressed and by $18 \mathrm{hr}$ postinfection $100 \%$ of the cell population were infected and advanced CPE was evident with all cells completely rounded and many cells detached from the glass.

b) A. albopictus

Confluent monolayers of A. albopictus were infected with different input multiplicities of Cocal virus and incubated at $30^{\circ} \mathrm{C}$. Virus was found to multiply in the cells producing a low titered infection involving, for the most part, only a small proportion of the cell population with no resulting CPE. As observed in Fig. 2, the input multiplicity employed during virus infection exerted a strong influence on subsequent virus titers, i.e. the virus yield per cell tended to be considerably higher after infection with an input multiplicity of 10 compared to infection with an input multiplicity of 0.1 .

Interestingly, unlike infection of $L$ cells where titers of extracellular virus were notably higher than $C A V$, no significant difference was found between the amount of extracellular and CAV in infected $\underline{A}$. albopictus cells. 
Fig. 2. Growth of Cocal virus in A. albopictus cells at $30^{\circ} \mathrm{C}$ with input multiplicities of 0.1 and 10 .

Extracellular virus

$\circ----\oplus$ Cell associated virus 


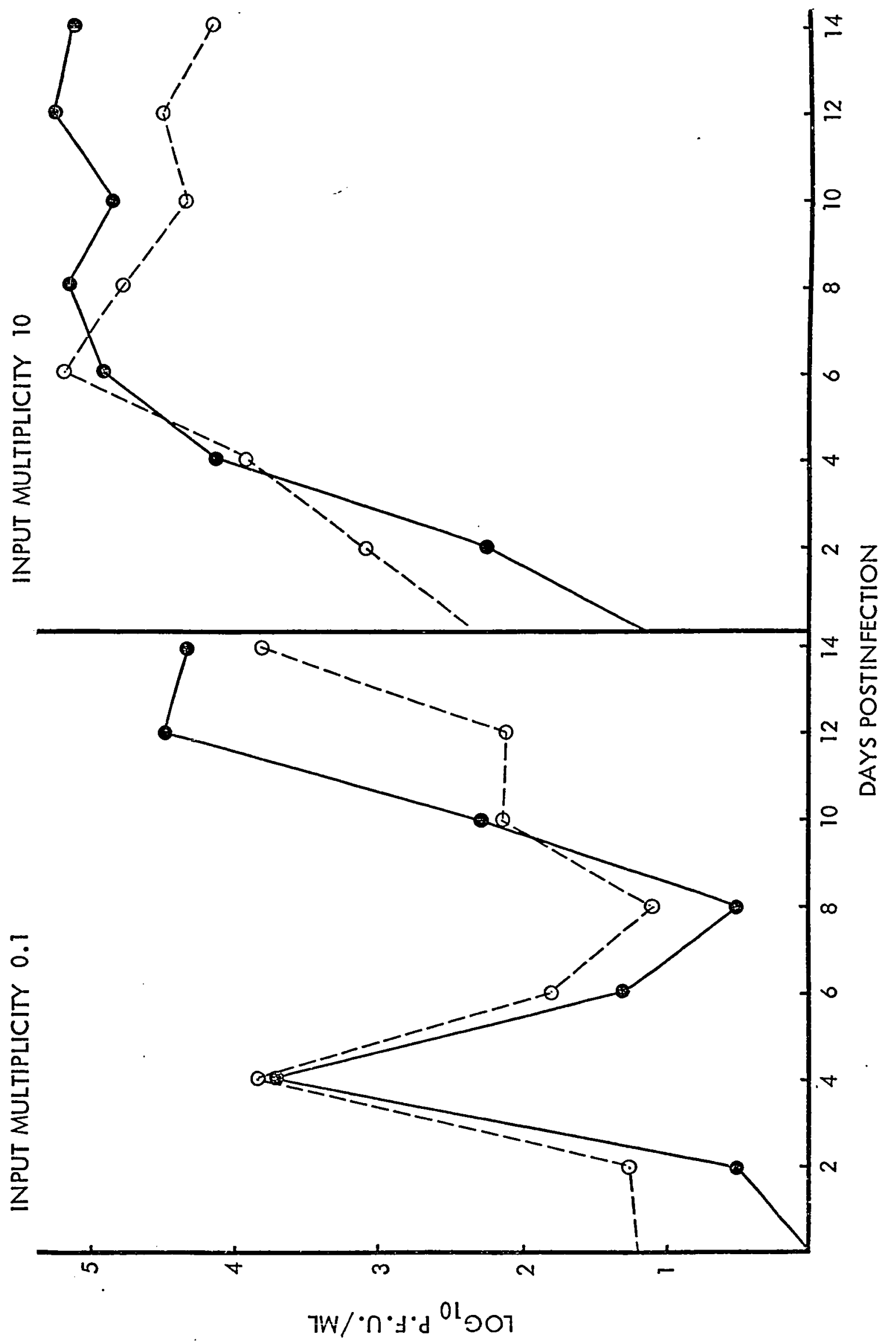


As recorded in Table 6, infection of A. albopictus cells with an input multiplicity of 10 or 1 yielded optimal virus titers under the experimental conditions employed. However, infection of cells with an input multiplicity of 100 plaque forming units (p.f.u.) of virus per cell resulted in markedly reduced virus titers although, initially, a large number of cells had been infected. In order to obtain an input multiplicity of 100 under the experimental conditions used, cells were infected with undiluted virus from a chick embryo grown Cocal pool (see Section III. B.) which contained numerous short particles as shown in Fig. 3.

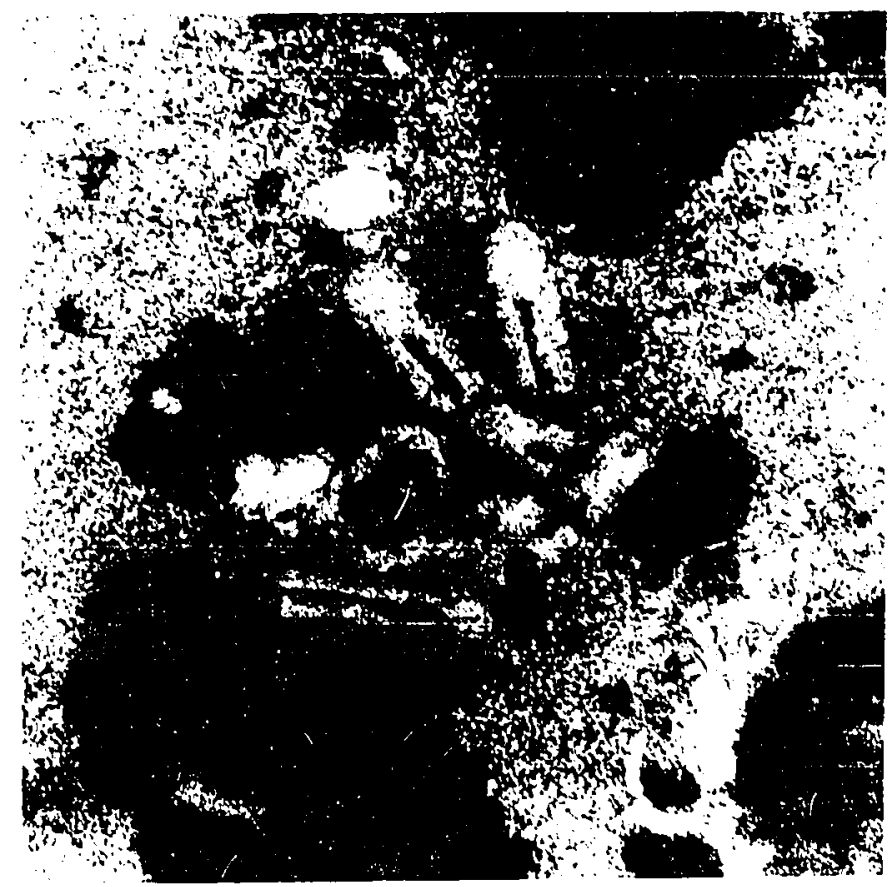

Fig. 3. Long and short particles of Cocal concentrated chick embryo pool. Magnification 120,000x. 
TABLE 6

Effect of Input Multiplicity on Virus Titer in A. albopictus

\begin{tabular}{|c|c|c|c|c|}
\hline & \multirow{2}{*}{$\begin{array}{l}\text { Postinfection } \\
\text { Sampling }\end{array}$} & \multicolumn{3}{|c|}{ Input Multiplicity } \\
\hline & & 100 & 10 & 1 \\
\hline \multirow{3}{*}{ Day 0} & Total cells/bottle & $5.0 \times 10^{4}$ & $1.4 \times 10^{5}$ & $4.2 \times 10^{5}$ \\
\hline & $\begin{array}{l}\text { Cell associated } \\
\text { virus (p.f.u./bottle) }\end{array}$ & $4.4 \times 10^{3}$ & $2.2 \times 10^{2}$ & $4.5 \times 10^{1}$ \\
\hline & Per cent infected cells & 86.0 & 1.86 & 0.20 \\
\hline \multirow{3}{*}{ Day 1} & Total cells/bottle & $1.5 \times 10^{5}$ & $1.9 \times 10^{5}$ & $6.6 \times 10^{5}$ \\
\hline & $\begin{array}{l}\text { Cell associated } \\
\text { virus (p.f.u./bottle) }\end{array}$ & $2.4 \times 10^{3}$ & $2.6 \times 10^{3}$ & $2.4 \times 10^{3}$ \\
\hline & Per cent infected cells & 3.0 & 3.05 & 0.45 \\
\hline \multirow{3}{*}{ Day 2} & Total cells/bottle & $3.4 \times 10^{5}$ & $2.6 \times 10^{5}$ & $2.8 \times 10^{5}$ \\
\hline & $\begin{array}{l}\text { Cell associated } \\
\text { virus (p.f.u./bottle) }\end{array}$ & $6.5 \times 10^{2}$ & $1.6 \times 10^{3}$ & $3.2 \times 10^{3}$ \\
\hline & Per cent infected cells & 0.06 & 0.35 & 1.0 \\
\hline \multirow{3}{*}{ Day 3} & Total cells/bottle & $6.3 \times 10^{5}$ & $4.0 \times 10^{5}$ & $4.8 \times 10^{5}$ \\
\hline & $\begin{array}{l}\text { Cell associated } \\
\text { virus (p.f.u./bottle) }\end{array}$ & $8.0 \times 10^{2}$ & $9.2 \times 10^{4}$ & $2.4 \times 10^{5}$ \\
\hline & Per cent infected cells & 0.03 & 12.0 & 25.0 \\
\hline \multirow{3}{*}{ Day 4} & Total cells/bottle & $5.7 \times 10^{5}$ & $4.6 \times 10^{5}$ & $2.6 \times 10^{5}$ \\
\hline & $\begin{array}{l}\text { Cell associated } \\
\text { virus (p.f.u./bottle) }\end{array}$ & $5.5 \times 10^{2}$ & $2.1 \times 10^{5}$ & $1.6 \times 10^{5}$ \\
\hline & Per cent infected cells & 0.02 & 9.57 & 11.15 \\
\hline
\end{tabular}


These short particles, which occurred in relatively small numbers and were easily diluted out, have been shown to cause autointerference with concomitant reduction of virus titers in other cell lines (Schaffer et al., 1969). It is possible that a similar phenomenon is occurring in infected A. albopictus cells.

c) A. aegypti

Infection of confluent monolayers of $\underline{A}$. aegypti at $30^{\circ} \mathrm{C}$ also resulted in a low titered non-cytolytic virus infection. The CAV titer in an infected monolayer of A. aegypti ( $10^{7}$ cells) did not exceed $10^{4}$ indicating an optimal p.f.u. per cell ratio of only 0.001 . As can be seen in Fig. 4 , the amount of virus produced in infected cultures tended to reach equivalent levels irrespective of the input multiplicity. Although adsorption of Cocal virus to $\underline{A}$. aegypti could not be measured by infective centers assay (Section B.1.), CAV titration just after adsorption revealed high virus titers indicating efficient adsorption of Cocal to $\underline{A}$. aegypti cells.

\section{Level of Susceptibility of Different Cell Lines}

Under conditions of the experiments undertaken where all unadsorbed virus was neutralized by Cocal immune serum after adsorption for $1 \mathrm{hr}$, a significant difference was found between the level of susceptibility of $\underline{A}$. albopictus compared to $\underline{A}$. aegypti and $L$ cells as noted in Table 7 . 
Fig. 4. Growth of Cocal virus in A. aegypti cells at $30^{\circ} \mathrm{C}$ with input multiplicities of 0.1 and 10 .
$\multimap$ Extracellular virus
$\Theta---\infty$ Cell associated virus 
64.

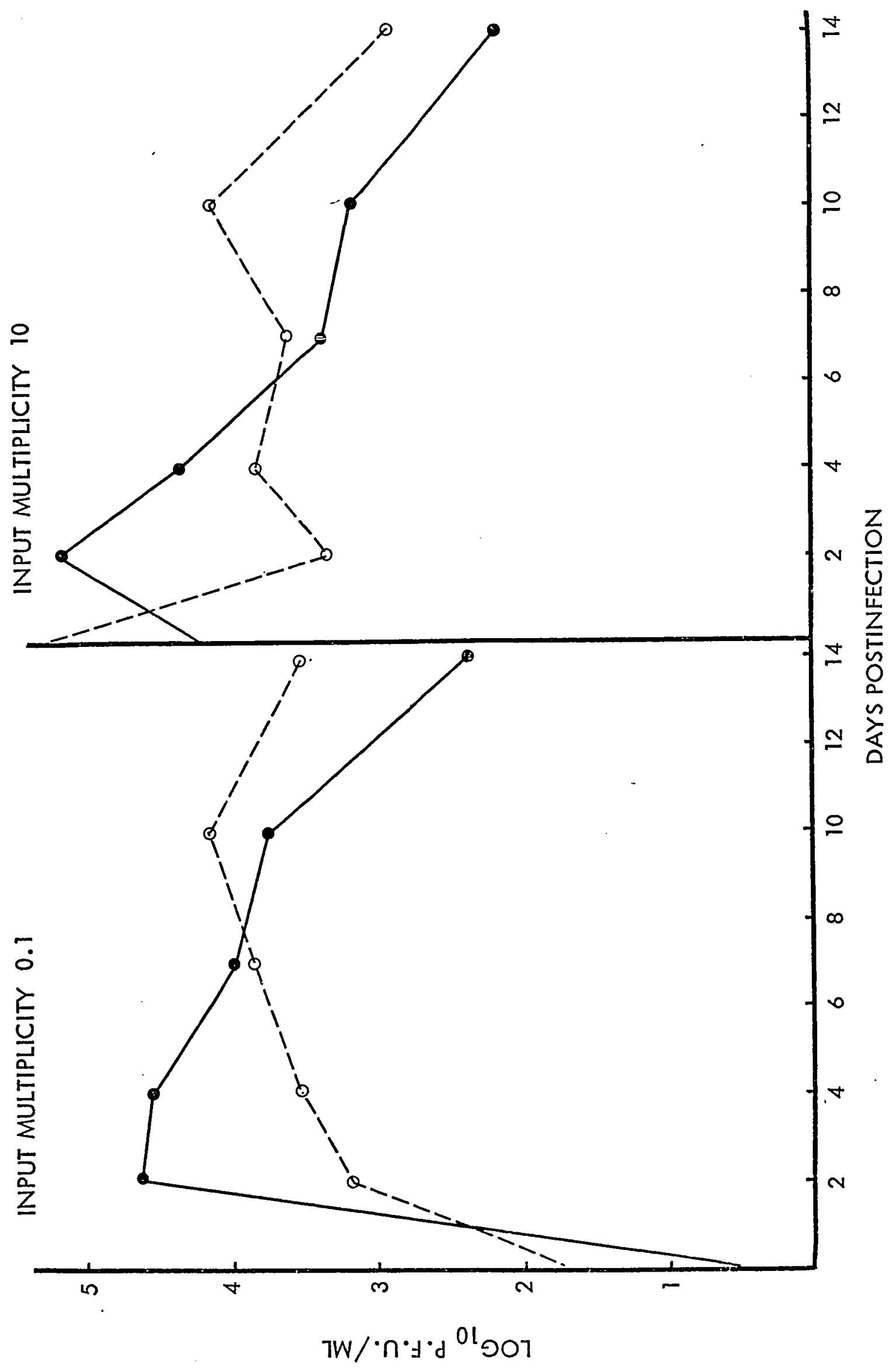


TABLE 7

$$
\text { Limits of Susceptibility of Cell Lines to Cocal Virus }
$$

\begin{tabular}{l|c|c|c|}
\hline & $\begin{array}{c}\text { Lowest quantity } \\
\text { of virus infecting } \\
\text { all cultures }\end{array}$ & $\begin{array}{c}\text { Number of cells } \\
\text { challenged }\end{array}$ & $\begin{array}{c}\text { Input } \\
\text { multiplicity }\end{array}$ \\
\hline Lells & 10 p.f.u. & $1 \times 10^{6}$ & 0.00001 \\
\hline A. albopictus & 10000 p.f.u. & $1 \times 10^{6}$ & 0.01 \\
\hline A. aegypti & 10 p.f.u. & $1 \times 10^{7}$ & 0.000001 \\
\hline
\end{tabular}

Monolayers of $\underline{A}$. albopictus were refractory to infection with an input multiplicity of less than 0.01 as measured by titrating for extracellular and CAV on chick embryo cells until 14 days postinfection. This may reflect the poor adsorption of Cocal virus to A. albopictus reported in Table 5.

\section{EFFORTS TO INCREASE VIRUS TITERS IN MOSQUITO CELLS}

Samples examined by electron microscopy from infected mosquito cells did not reveal virus particles presumably due to the low number of infected cells. 
Therefore, efforts were undertaken to increase virus titers in infected cells. Unless otherwise stated, all subsequent virus titrations refer to CAV only. Extracellular virus titrations were also performed but tended to give titers comparable to CAV titers.

\section{Effect of DEAE Dextran}

Pattyn and De Vleesschauwer (1970) showed that when DEAE dextran was added to a blood-virus meal fed to A. aegypti, the infection rate of several arboviruses was greatly enhanced. Efforts were undertaken to reproduce this phenomenon in vitro.

In these experiments, DEAE dextran at a final concentration of $0.1 \%$ was incorporated into the PBS virus diluent and allowed to act during adsorption of virus to cells. The DEAE dextran was then removed (except possibly for small amounts which may have coated the cells) prior to addition of MM 97-3 and initiation of growth studies.

Upon infection of cells with an input multiplicity of 0.1 of virus containing DEAE dextran, the amount of virus initially adsorbing to both $\underline{A}$. albopictus and A. aegypti cells was enhanced as noted in Fig. 5 and 6 . This greater amount of initially infected cells manifested itself throughout the entire growth cycle with a greater yield of virus per cell in the case of A. albopictus but had little influence on virus titer in $\underline{A}$. aegypti cells.

The enhancement of Cocal infection by DEAE dextran was also demon- 
Fig. 5. Effect of DEAE dextran suring Cocal virus adsorption on virus titer in A. albopictus cells at $30^{\circ} \mathrm{C}$.

Q-- - $\odot$ No DEAE dextran adsorption

$\longrightarrow$ Adsorption with DEAE dextran 
67.

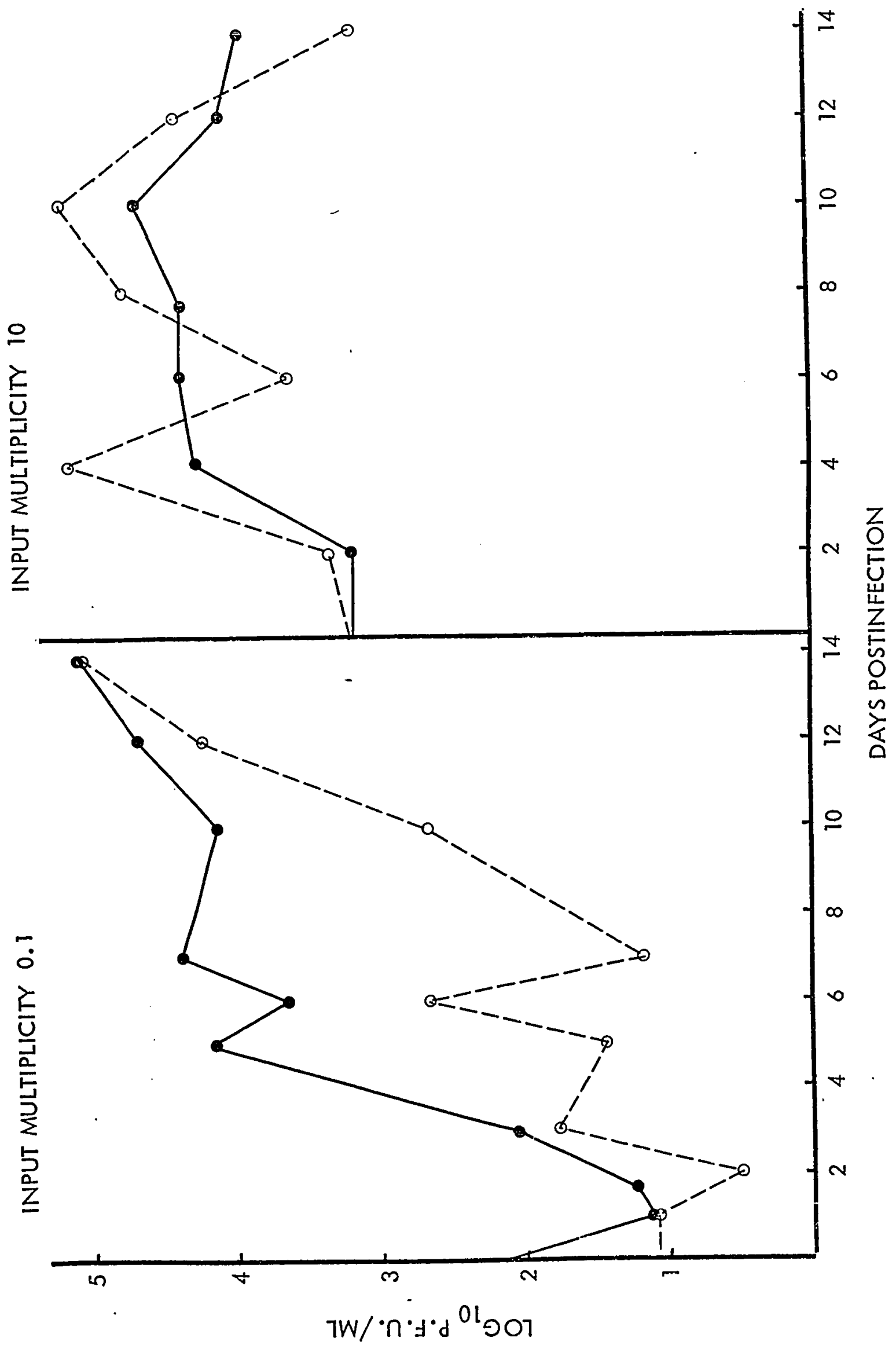


Fig. 6. Effect of DEAE dextran during Cocal virus adsorption on virus titer in A. aegypti cells at $30^{\circ} \mathrm{C}$ ロ-- $\boxminus$ No DEAE dextran adsorption $\longrightarrow$ Adsorption with DEAE dextran 
68.

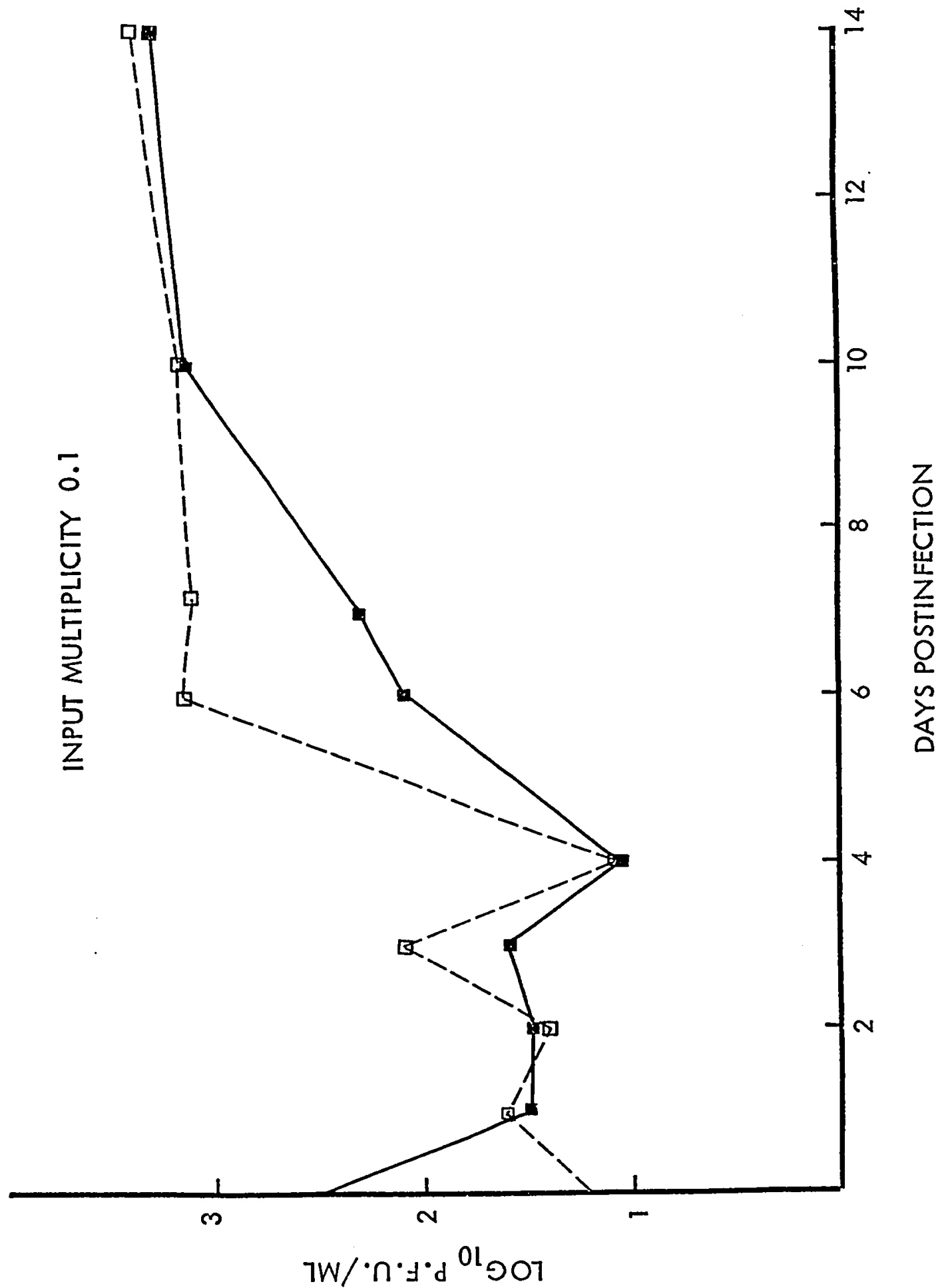


strated by use of input multiplicities of less than 0.01 . Whereas $A$. albopictus cells were normally refractory to infection with virus at a low input multiplicity (see Table 7), culitures were successfully infected at reduced input multiplicities if virus was adsorbed to cells in the presence of DEAE dextran.

However, increased adsorption of Cocal to A. albopictus occurred only under conditions of low input multiplicity. DEAE dextran did not increase virus adsorption nor subsequent virus titers when applied under conditions of high input multiplicity as noted in Fig. 5.

\section{Effect of Serum Concentration}

Kouroupis and Sabina (1971) showed that addition of serum to maintenance medium markedly enhanced VSV progeny in an infected bovine kidney cell line.

The effect of serum concentration on yield of Cocal virus in A. albopictus was studied by increasing the concentration of fetal calf serum (FCS) in the maintenance medium. Whereas normal mosquito maintenance medium contains $3 \%$ FCS (MM 97-3), the FCS concentration was increased to $10 \%(M M 90-10)$ and $20 \%$ (MM 80-20). This latter formula represents the normal growth medium (see Appendix) used for the mosquito cell lines.

Results are presented in Fig. 7. Serum concentration did not appear to exert much influence on increase of virus titer except for the 8 days postinfection sampling where cells maintained under MM 80-20 were estimated to have almost 
Fig. 7. Effect of serum concentration on Cocal virus titer in A.

albopictus cells at $30^{\circ} \mathrm{C}$ infected with an input multiplicity

of 0.1 .

$\longleftarrow-\longrightarrow M M 97-3$

$\leadsto-\rightarrow M M 90-10$

$\longrightarrow$ MM 80-20 
7

70.

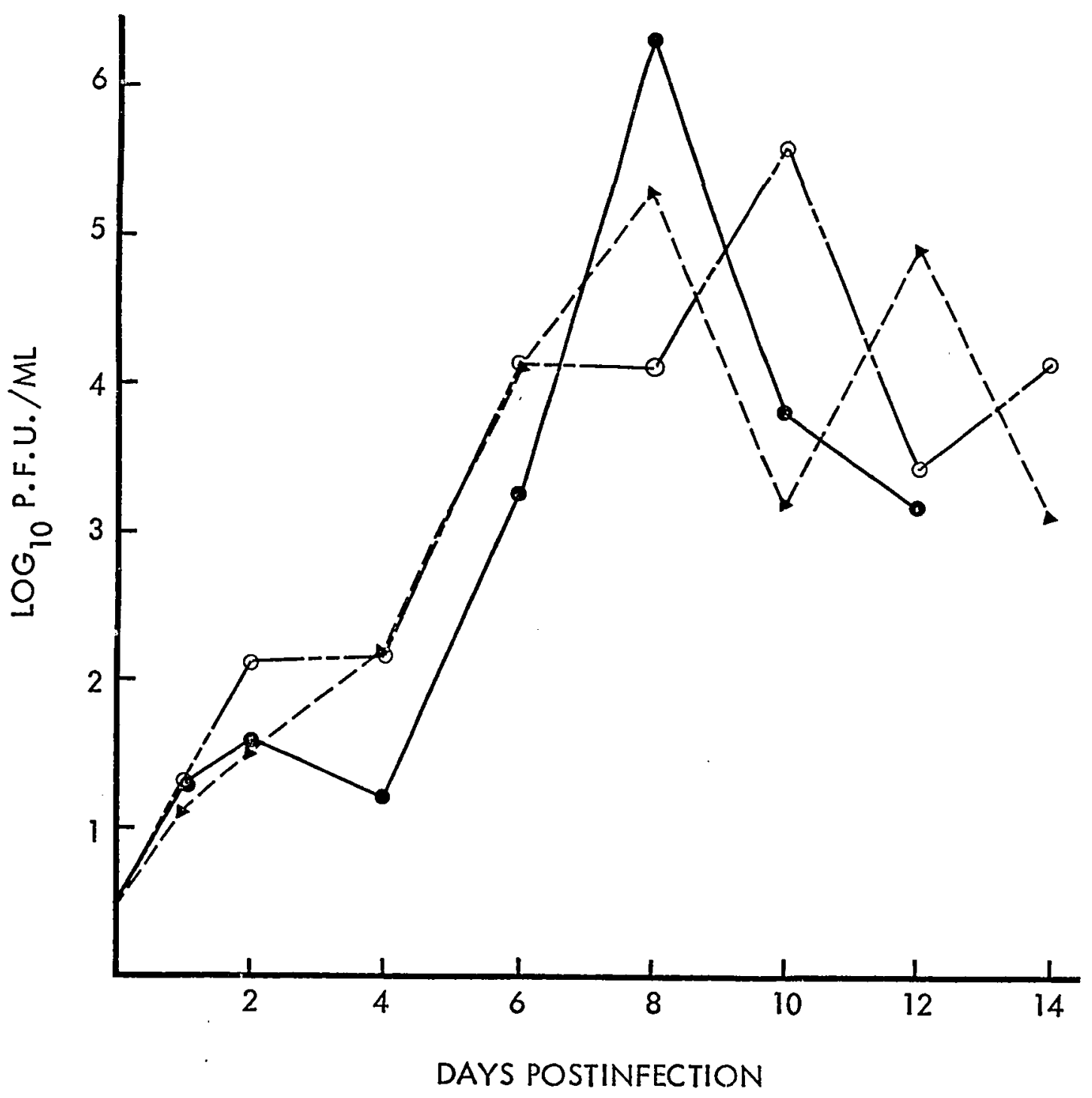

$$
\% \text { INFECTED }
$$

CELLS

$\begin{array}{llllllll}\text { MM 97-3 } & 0.0185 & 0.0006 & 0.5882 & 0.6909 & 13.0 & 0.6102 & 1.03 \\ \text { MM 90-10 } & 0.0024 & 0.0009 & 0.8116 & 9.24 & 0.0528 & 18.10 & 0.9000 \\ \text { MM 80-20 } & 0.0108 & 0.0017 & 0.3190 & 46.84 & 0.3900 & 0.6520 & -\end{array}$


$47 \%$ infected cells. However, aside from this one occasion, no definite trend was found for increased virus production with increase of serum concentration and in all samplings the calculated number of p.f.u. per cell was always well below 1.0.

\section{Effect of Temperature}

Although it was observed that mosquito cells did not grow at $37^{\circ} \mathrm{C}$ and did not maintain particularly well at this temperature for prolonged periods, it was decided to determine whether increased temperature of incubction might induce higher titers of virus in infected cells.

a) Infection with Low Input Multiplicity of Virus

Infection of A. albopictus cells with an input multiplicity of 0.1 followed by incubation at $37^{\circ} \mathrm{C}$ resulted in increased virus titers as recorded in Fig. 8 . It may be seen that virus production was decidedly enhanced by incubation of infected cells at $37^{\circ} \mathrm{C}$ and infective center assays revealed a larger percentage of infected cells. However, despite this increased virus production, the estimated number of p.f.u. per cell still remained well be low 1.0 .

b) Infection with High Input Multiplicity of Virus

Infection of A. albopictus cells at an input multiplicity of 10 with subse- 
Fig. 8. Effect of temperature on Cocal virus titer in A. albopictus

cells infected with an input multiplicity of 0.1 .

- $-\cdots$ Incubation at $30^{\circ} \mathrm{C}$

$\longrightarrow$ Incubation at $37^{\circ} \mathrm{C}$ 


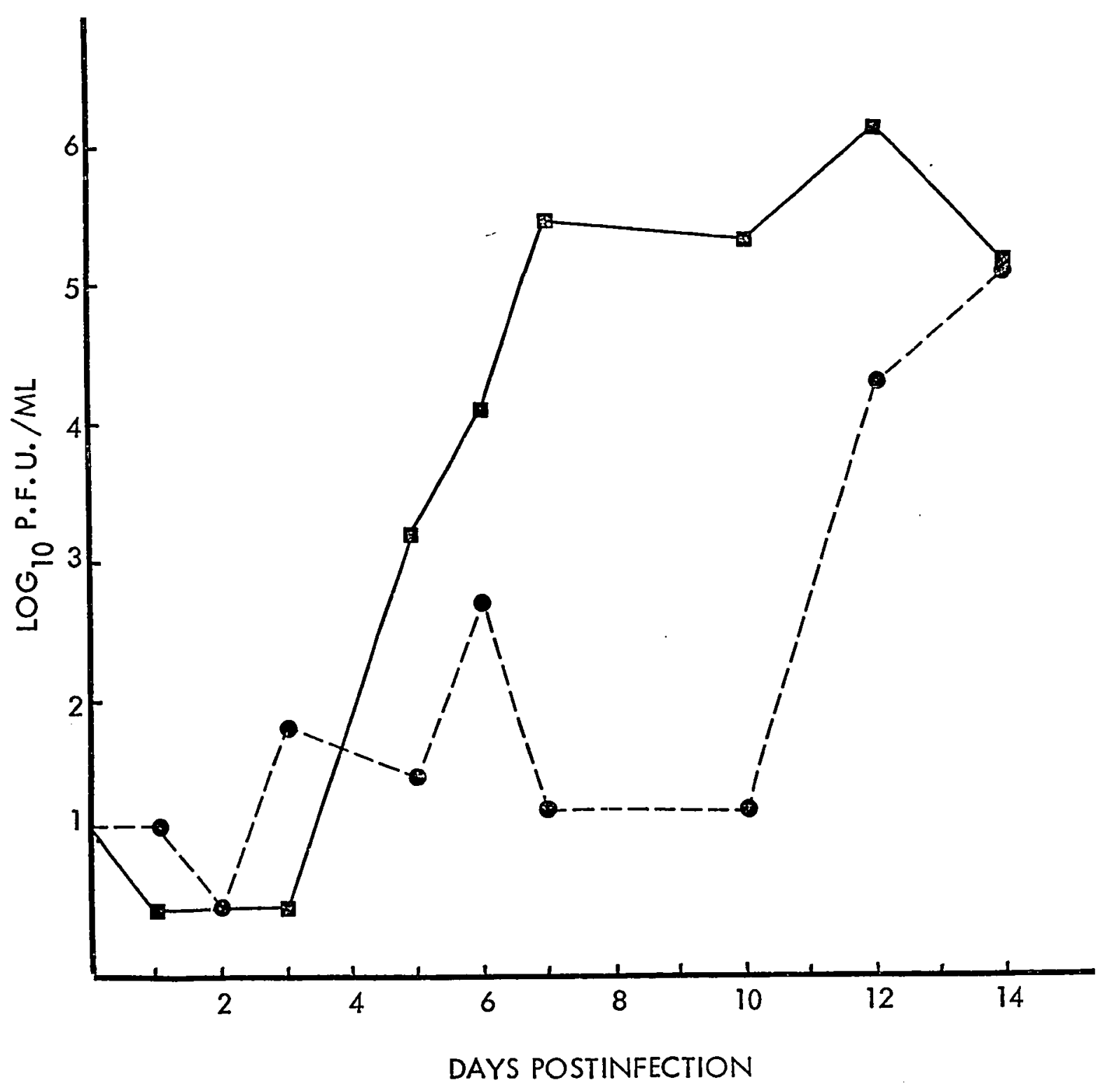

$\%$ INFECTED

CELLS

$\begin{array}{llllll}30^{\circ} \mathrm{C} & 0.0024 & 0.1143 & 0.0050 & 0.2500 & 10.33 \\ 37^{\circ} \mathrm{C} & 0.0274 & 11.37 & 22.33 & 16.67 & 29.64\end{array}$


quent incubation at $37^{\circ} \mathrm{C}$ revealed that higher temperature did indeed markedly increase virus titers as noted in Fig. 9.

Cultures incubated at $37^{\circ} \mathrm{C}$ and sampled 2 days postinfection were estimated to contain $100 \%$ infected cells and an average virus titer of several p.f.u. per cell. However, despite these initially high virus titers, by day 4 postinfection only $6 \%$ of the cell population was calculated to be infected by infective center assay in cells incubated at $37^{\circ} \mathrm{C}$, and the p.f.u. per cell ratio reverted to be low 1.0. It is uncertain whether heavily infected cells have lysed during this period but no gross CPE was evident. Cells in both infected and uninfected cultures looked poorly after $2-4$ days incubation at $37^{\circ} \mathrm{C}$ and it would be difficult to distinguish any slight cellular alterations that might have occurred. A closer analysis of virus replication during early stages of infection at $37^{\circ} \mathrm{C}$ is presented in Table 8 . It may be seen that $100 \%$ infection of cells occurred as early as $24 \mathrm{hr}$ postinfection. However, virus titer continued to build in infected cells and the p.f.u. per cell ratio increased from 1.93 at $24 \mathrm{hr}$ to 17. 11 by $60 \mathrm{hr}$ postinfection.

The effect of $37^{\circ} \mathrm{C}$ on significantly increasing Cocal replication in A. albopictus did not occur for the A. aegypti cell line. As observed in Fig. 10, when A. aegypti cells were infected with an input multiplicity of 10 and incubated at $37^{\circ} \mathrm{C}$ a slight increase in virus production was found. However, despite this increase, a low p.f.u. per cell ratio was maintained. 
Fig. 9. Effect of temperature on Cocal virus titer in A. albopictus cells infected with an input multiplicity of 10 .

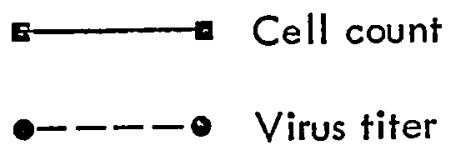


74.

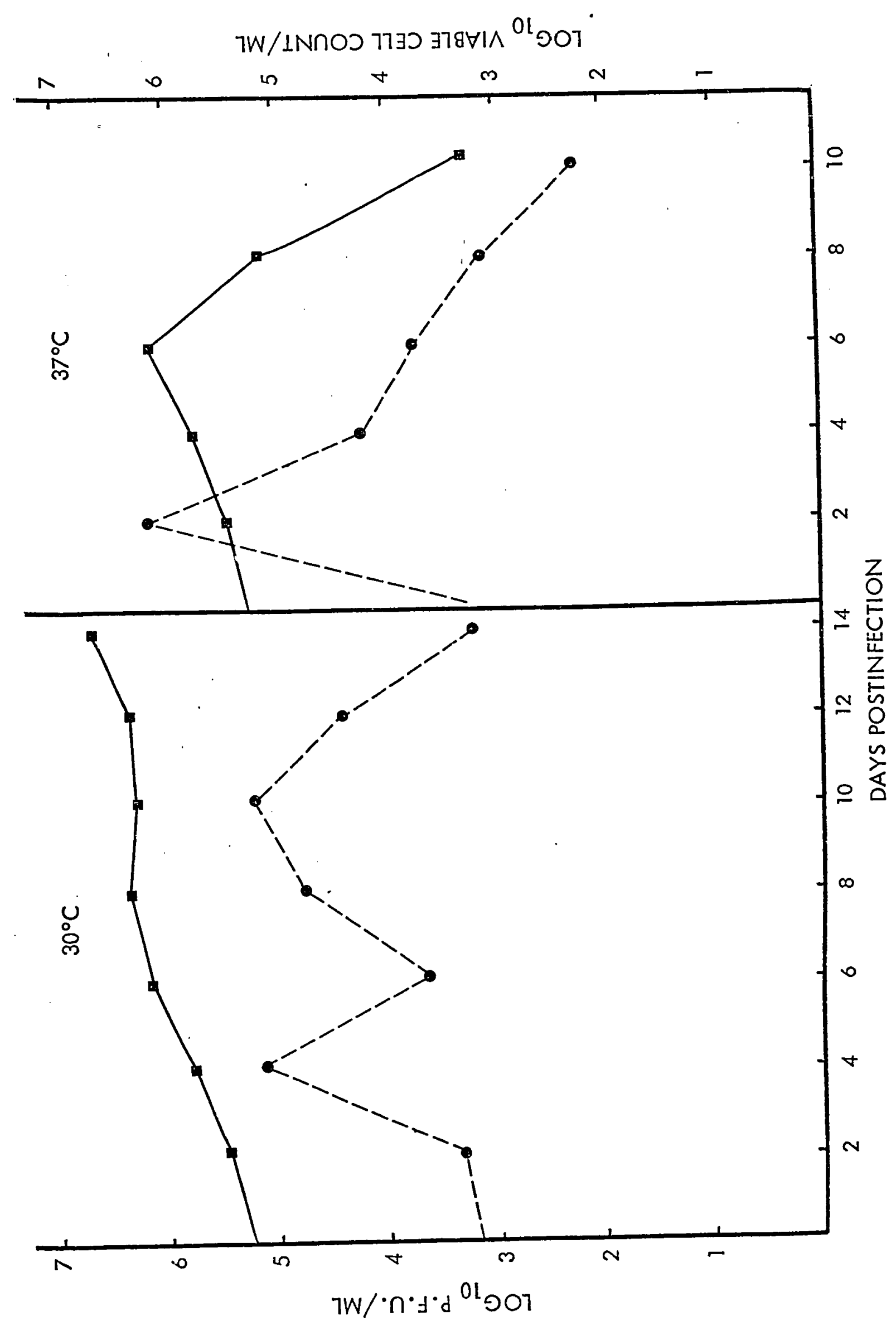


75.

TABLE 8

Effect of Temperature on Virus Production in A. albopictus with an Input Multiplicity of 10.

\begin{tabular}{|c|c|c|c|}
\hline & & $30^{\circ} \mathrm{C}$ & $37^{\circ} \mathrm{C}$ \\
\hline $6 \mathrm{hr}$ & $\begin{array}{l}\text { Per cent infected cells } \\
\text { p.f.u. / cell }\end{array}$ & $\begin{array}{c}0.54 \\
0.0032\end{array}$ & $\begin{array}{r}0.67 \\
0.0024\end{array}$ \\
\hline $12 \mathrm{hr}$ & $\begin{array}{l}\text { Per cent infected cells } \\
\text { p.f.u./cell }\end{array}$ & $\begin{array}{c}1.20 \\
0.0157\end{array}$ & $\begin{array}{r}2.39 \\
0.0136\end{array}$ \\
\hline $18 \mathrm{hr}$ & $\begin{array}{l}\text { Per cent infected cells } \\
\text { p.f.u./cell }\end{array}$ & $\begin{array}{c}0.97 \\
0.0067\end{array}$ & $\begin{array}{r}16.18 \\
0.0956\end{array}$ \\
\hline $24 \mathrm{hr}$ & $\begin{array}{l}\text { Per cent infected cells } \\
\text { p.f.u./cell }\end{array}$ & $\begin{array}{c}0.65 \\
0.0048\end{array}$ & $\begin{array}{r}100 \\
1.93\end{array}$ \\
\hline $36 \mathrm{hr}$ & $\begin{array}{l}\text { Per cent infected cells } \\
\text { p.f.u./cell }\end{array}$ & $\begin{array}{c}0.68 \\
0.0114\end{array}$ & $\begin{array}{r}100 \\
10.43\end{array}$ \\
\hline $60 \mathrm{hr}$ & $\begin{array}{l}\text { Per cent infected cells } \\
\text { p.f.u./cell }\end{array}$ & $\begin{array}{c}5.0 \\
0.1900\end{array}$ & $\begin{array}{r}100 \\
17.11\end{array}$ \\
\hline
\end{tabular}


Fig. 10. Effect of temperature on Cocal virus titer in A. aegypti cells

infected with an input multiplicity of 10.

$\rightleftarrows$ Cell count

$\triangle-\cdots$ Virus titer 
76.

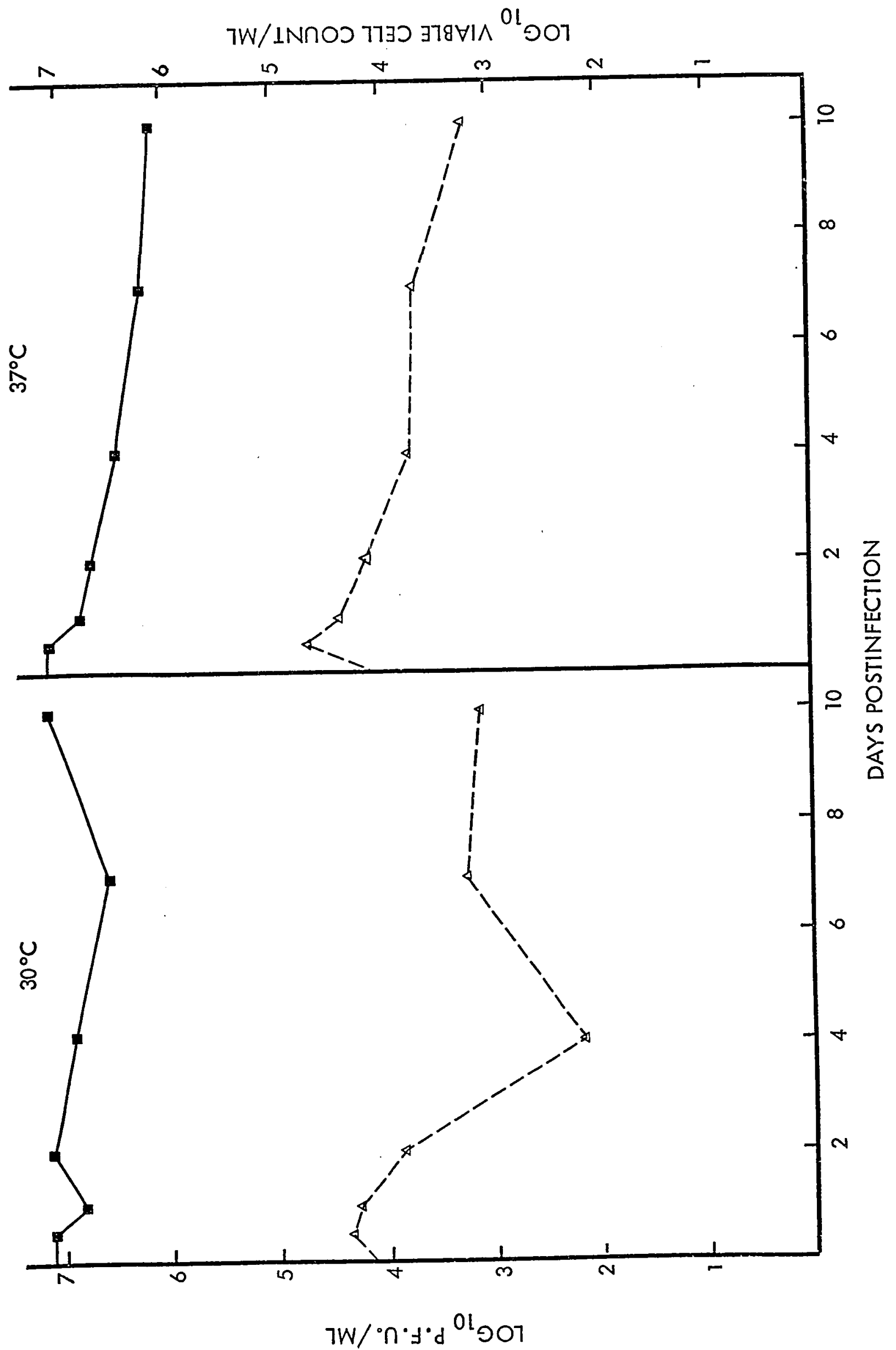




\section{STUDIES ON PERSISTENT INFECTION OF MOSQUITO CELL LINES}

\section{Development of Persistently Infected Cultures}

During previous experiments it was observed that both $\mathrm{A}$. aegypti and A. albopictus cell lines upon infection with Cocal virus yielded infective viral particles without concomitant CPE during the entire sampling period. Attempts were undertaken to subculture these virus infected cells to determine whether infected mosquito cells would grow and establish persistently infected cell lines. Infected cultures of $\underline{A}$. albopictus cells were transferred by trypsinization whereas cultures of $\underline{A}$. aegypti were transferred by scraping cells off the glass and by vigorously pipetting to break up cell clumps. Pronase was not used to transfer persistently infected A. aegypti cells since it was found to reduce CAV titers during sampling. The persistently infected mosquito cell lines grew readily upon subculture.

Attempts were made to transfer $L$ cells infected with Cocal virus, since a few rounded cells remained on the glass despite extensive CPE. These latter attempts were unsuccessful.

Initially, nine separate cultures from both $\underline{A}$. aegypti and $\underline{A}$. albopictus were transferred but only four cultures of each were maintained beyond 10 transfers although all cultures remained persistently infected through the first 10 transfers. Four cultures from each cell line were then continuously transferred for up to 60 passages. Transfers and sampling for virus titer of persistently infected cell lines 
were always done soon after cell cultures reached confluency.

Titers of extracellular virus recorded for 60 transfers are presented in Table 9. All measurements were based on p.f.u. titers in chick embryo as per usual. It may be seen that two of four persistently infected cultures of A. albopictus appear to have lost virus by passages 20 and 30 . Virus also could not be detected in these cultures by i.c. inoculation into suckling mice, by titration on BHK-2l, nor by cocultivation of cells on chick embryo as per infectious center assay (see Section III. H.2.). However, in the two other A. albopictus cultures, virus was maintained at approx. the same level for as long as the cells were transferred. Infective center assays revealed that infection tended to remain restricted to less than $1 \%$ of the cell population during these transfers.

All four persistently infected cultures of $\underline{A}$. aegypti retained virus through all transfers. Whereas the passage 60 carrier culture (c.c.) 5 was negative upon titration in chick embryo, virus was detected upon simultaneous titration in BHK $\cdots 21$. One interesting observation during passage of persistently infected cells was the development of small plaques upon persistent passage. Normal plaque Cocal virus initially used to infect both mosquito cell lines produced plaques of $3-5 \mathrm{~mm}$ diameter in chick embryo. At passage 10 level most plaques were $3-5 \mathrm{~mm}$ as in the original inoculum although smaller plaque variants of $1-3 \mathrm{~mm}$ were observed. By passage 20 approx. $50 \%$ of all Cocal progeny in A. aegypti cells were $1-3 \mathrm{~mm}$ diameter whereas plaques of $3-5 \mathrm{~mm}$ diameter still predominated in $\underline{A}$. albopictus persistently infected cells. 
TABLE 9

Effect of Passage on Persistent Infection of Mosquito Cell Lines

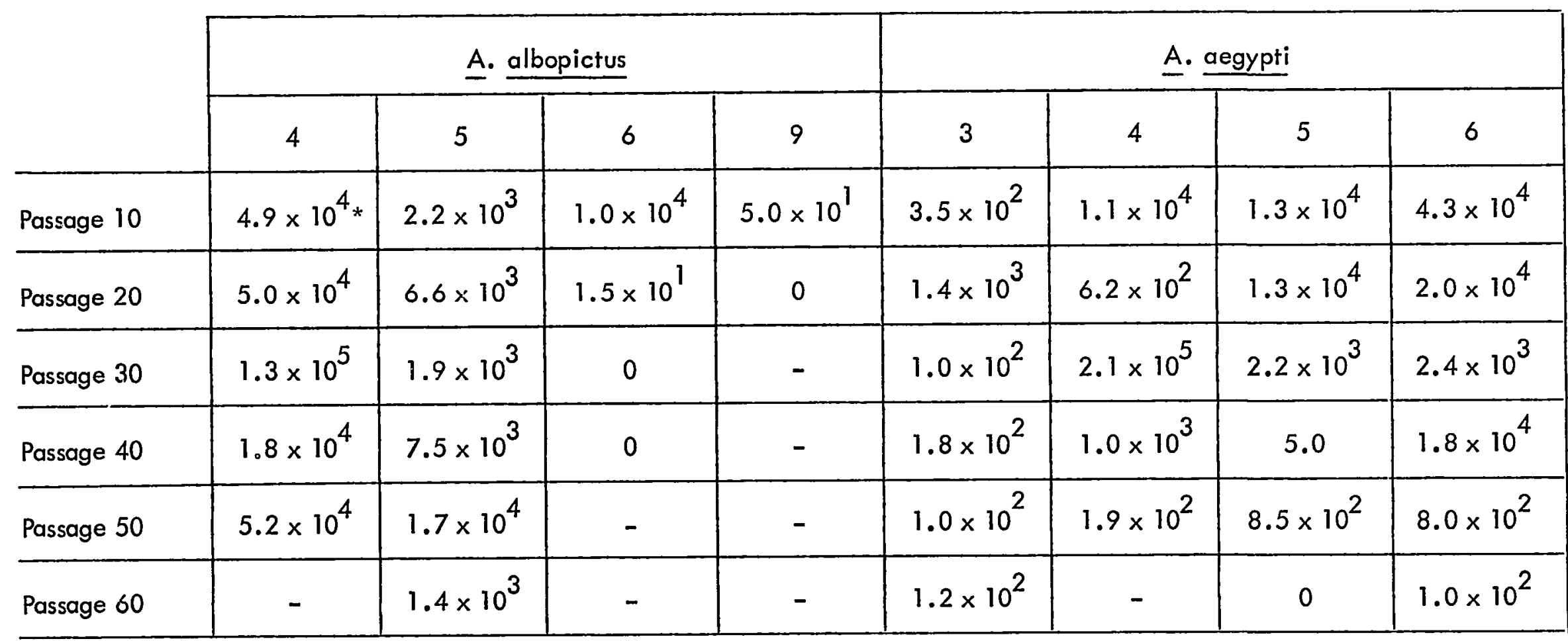

* Results expressed as p.f.u./ml 
80.

Plaque size of Cocal virus continued to decrease upon persistent passage. By passage 30 all virus progeny from A. aegypti alternated between $1-3 \mathrm{~mm}$ and less than $1 \mathrm{~mm}$ diameter. Virus plaques from A. aegypti cultures were all pinpoint (less than $1 \mathrm{~mm}$ diameter) by passage 50 .

Decrease in plaque size also occurred in Cocal from $\underline{A}$. albopictus persistently infected cells. Plaques of all sizes ranging from $3-5 \mathrm{~mm}, 1-3 \mathrm{~mm}$, and less than $1 \mathrm{~mm}$ diameter were found in passage 30 material. Passage 40 and 50 material all contained plaques of only $1-3 \mathrm{~mm}$ and less than $1 \mathrm{~mm}$ diameter. However plaques of $1-3 \mathrm{~mm}$ still predominated in passage 50 material unlike A. aegypti passage 50 where all plaques were less than $1 \mathrm{~mm}$ diameter.

\section{Maintenance of Persistent Infection under Immune Serum}

Attempts were made to see whether virus infection could be maintained in cells in the presence of Cocal immune serum.

A. albopictus c.c. ${ }_{5}$ cells at passage 1 were trypsinized and transferred to 4 new bottles. To 2 bottles was added MM 80-20 while to 2 other bottles was added MM 80-20 containing a 10\% concentration of Cocal antiserum prepared in rabbits. Cells were subsequently passaged 10 times in the presence of Cocal immune serum. At each passage, growth medium containing antiserum was tested for virus but no extrace llular virus was detected. Titrations for CAV were performed at each transfer and the results are presented in Fig. 11. 
Fig. 11. Effect of Cocal antiserum on Cocal persistent infection of A. albopictus cells at $30^{\circ} \mathrm{C}$.

$\longrightarrow--\rightarrow$ No antiserum

$\longrightarrow$ Medium containing Cocal antiserum 
81.

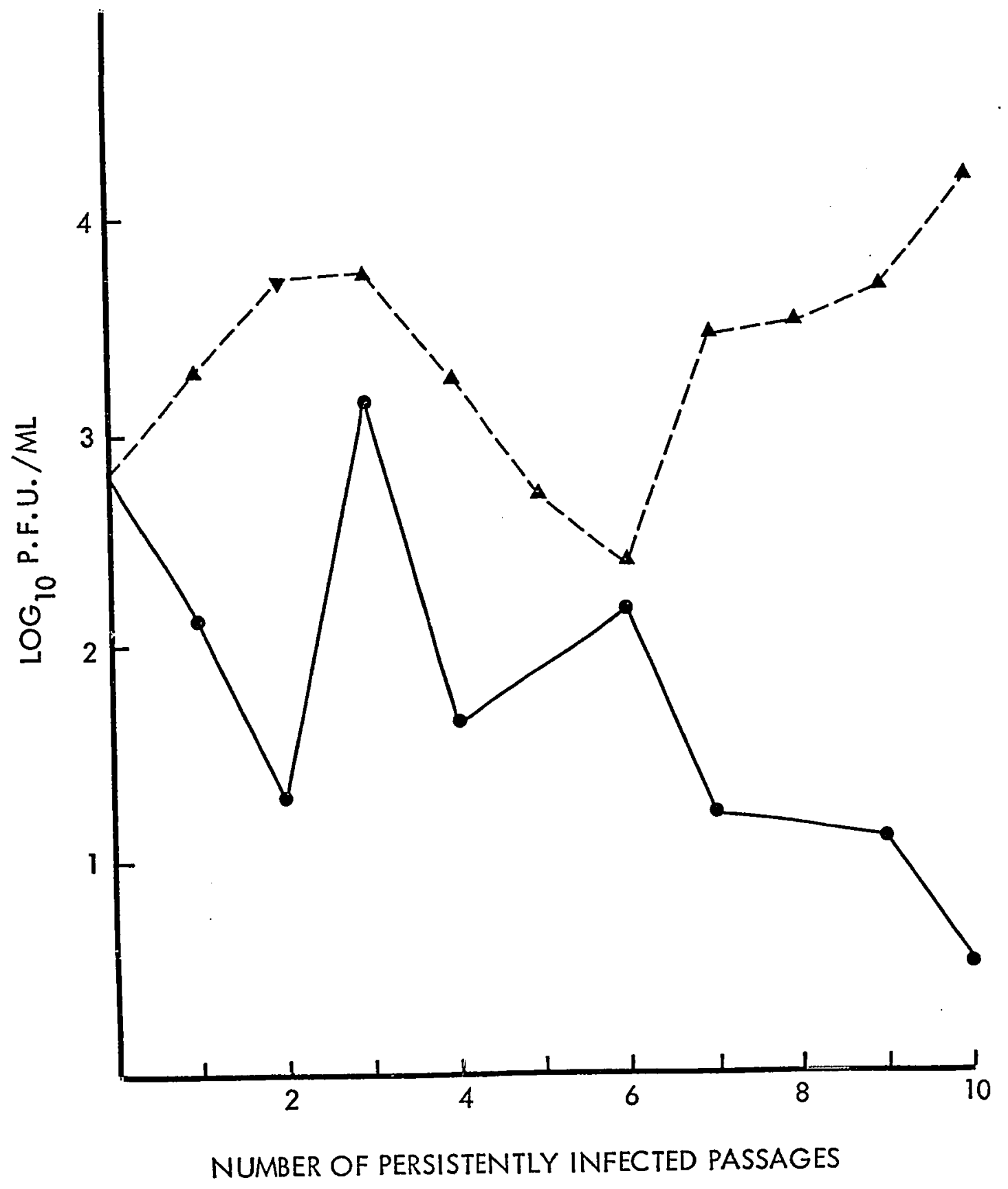


82.

Persistent infection was maintained in the presence of immune serum although virus titers were found to decline. This would indicate that infected cells can multiply and sustain virus infection.

3. Virus Production during Growth of A. albopictus Persistently Infected Cells

Growth studies did not reveal any apparent differences in growth rate between $\underline{A}$. albopictus uninfected and persistently infected cells as exemplified in Fig. 12.

Studies of virus production during growth of $\underline{A}$. albopictus $c . c \cdot{ }_{5}$-passage 30 persistently infected cells revealed a low titered infection with the per cent infected cells always lower than $0.25 \%$ and a p.f.u. per cell ratio never higher than 0.004. As observed in Fig. 12, no significant fluctuation in virus titers was observed during the entire growth phase.

\section{Relative Sensitivities of Different Host Systems to Cocal Virus}

Subsequent to the observation that Cocal virus from persistently infected cells produced plaques of decreased size on chick embryo (Section D. 1.), comparative susceptibility of different host systems to Cocal virus was studied.

In preliminary experiments, chick embryo was found to provide a more sensitive assay system for Cocal than BHK-21, Hep-2, and L cells (see also Hull, 1970). 
Fig. 12. Cocal virus titer during growth of A. albopictus persistently infected cells at $30^{\circ} \mathrm{C}$.

$$
\begin{aligned}
& \longrightarrow \text { Passage } 30 \text { uninfected cells - cell count } \\
& \text { cell count }
\end{aligned}
$$


83.

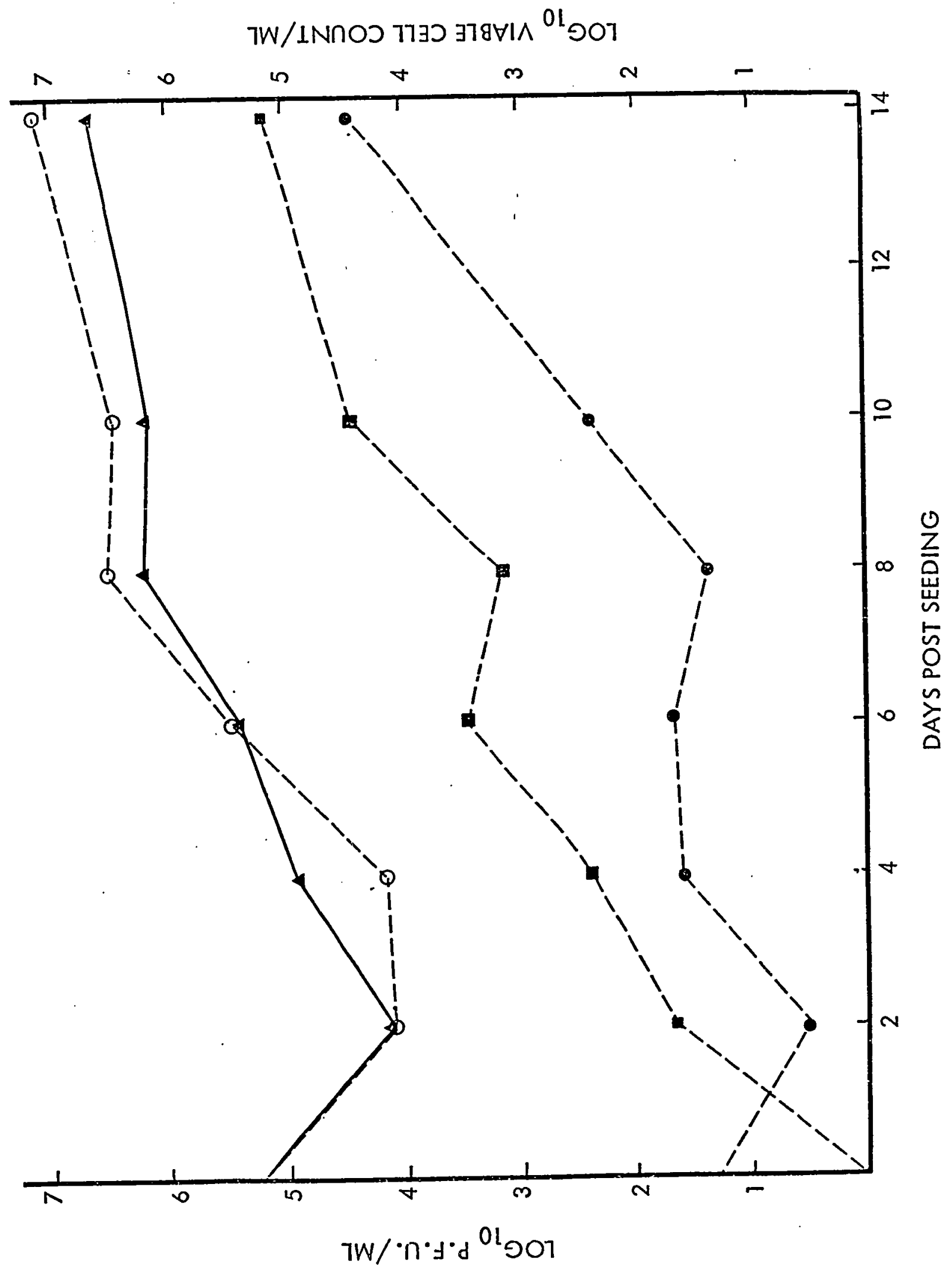


This observation is documented in Fig. 13 where a stock pool of Cocal yielded a titer of $1.8 \times 10^{8}$ p.f.u. per $\mathrm{ml}$ in chick embryo but only $1.5 \times 10^{7}$ p.f.u. per $\mathrm{ml}$ in BHK-21. However, as recorded in Fig. 13, the relative sensitivities of these two cell lines to virus from persistently infected mosquito cells changed and, by passage 60, BHK-21 was found to be more sensitive than chick embryo cells. Also, as mentioned previously (Section D. 1.), Cocal virus produced by A. aegypti

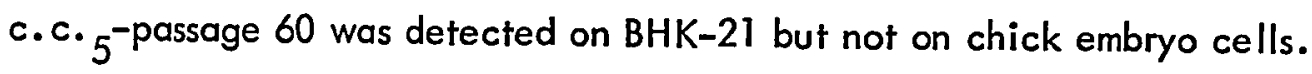
Virus from persistently infected cells was found to kill suckling mice after i.c. inoculation with no defin ite change in virulence relative to growth in chick embryo and BHK-21 cells as shown in Fig. 13. However, a definite reduction of virulence in adult mice inoculated i.c. was observed. Whereas Hull (1970) reported that $100 \%$ mortality occurred in adult mice challenged with 180 p.f.u. of virus (as quantitated in chick embryo), this observation did not hold true for Cocal from persistently infected cells.

\section{Studies on Small Plaque Cocal from Persistently Infected Cells}

a) Growth of Small Plaque Pool

In order to compare characteristics of small plaque Cocal from persistently infected cells with normal plaque Cocal, a small plaque pool was grown from

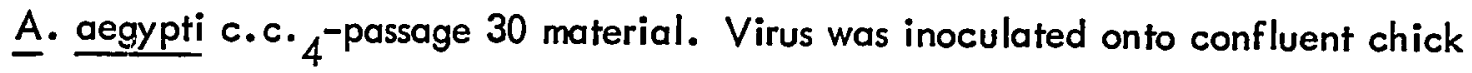
embryo monolayers and cells were incubated at $37^{\circ} \mathrm{C}$. After $48 \mathrm{hr}$, when CPE was 
Fig. 13. Comparative sensitivities of different host systems to Cocal virus. 


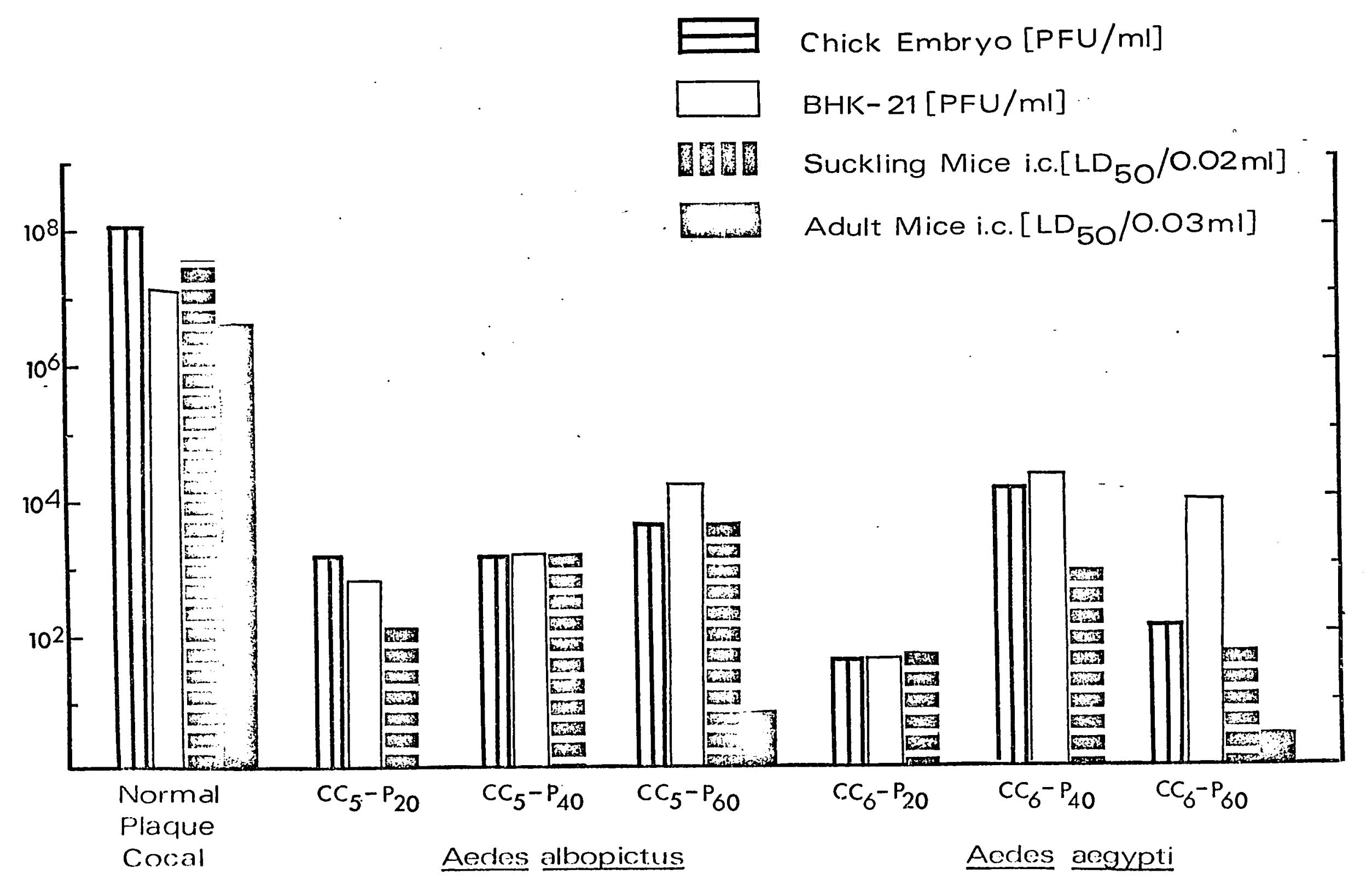


evident, the pool was harvested as per usual (see Section III. B. 1.) and stored at $-70^{\circ} \mathrm{C}$.

The small plaque pool was found to have a titer of $1.2 \times 10^{6}$ p.f.u. per $\mathrm{ml}$ in chick embryo, and all plaques were $1 \mathrm{~mm}$ in diameter or less by $48 \mathrm{hr}$ postinfection. A picture of normal and small plaque Cocal virus is presented in Fig. 14. Virus was identified as Cocal by plaque neutralization. Eighty per cent reduction of normal plaque Cocal occurred at a serum dilution of $1 / 1000$ while eighty per cent reduction of small plaque Cocal occurred at only a $1 / 500$ dilution of the same serum.

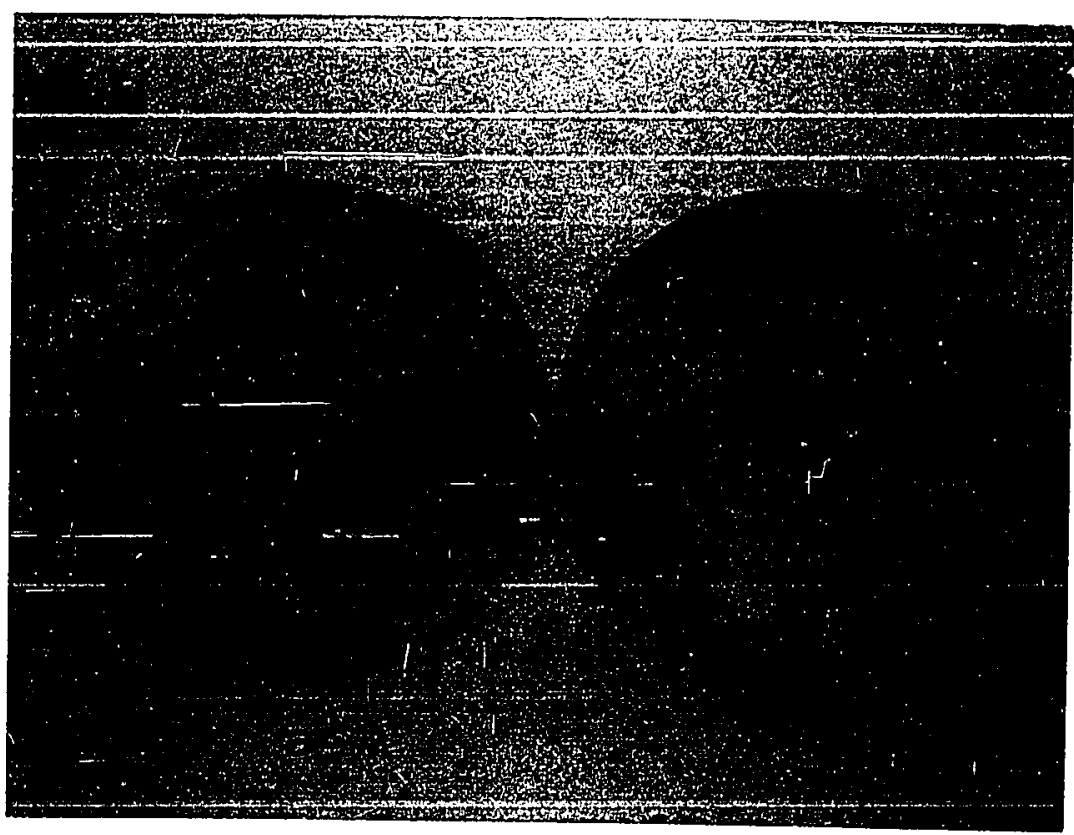

Fig. 14. Cocal virus plaques in chick embryo

a) normal plaque Cocal

b) small plaque Cocal 
b) Effect of Temperature and Cell Lines on Plaque Size

Small plaque Cocal was grown from mosquito cells incubated at $30^{\circ} \mathrm{C}$ but was characterized as to its small plaque nature by titration in chick embryo at $37^{\circ} \mathrm{C}$. Therefore, it was important to ascerta in that small plaque size was not simply the result of temperature sensitivity. Plaque titrations of normal and small plaque Cocal were performed in chick embryo at $30^{\circ} \mathrm{C}$. Under these conditions normal plaque Cocal showed slightly reduced size, i.e. 2 - $3 \mathrm{~mm}$ diameter at $48 \mathrm{hr}$ postinfection, but all small plaques remained at less than $1 \mathrm{~mm}$ diameter.

Normal and small plaque Cocal were tested for plaque size in BHK-21 and $\mathrm{L}$ cells at $37^{\circ} \mathrm{C}$ as recorded in Table 10. It may be seen that the small plaque characteristic is common to these cell lines as well. However, plaques produced by small plaque virus in BHK-21 were not as reduced in size compared to the normal plaque pool as in the chick embryo and L cell systems.

\section{c) Effect of Possible Plaque Inhibitors}

An experiment was undertaken to determine whether the Cocal small plaque variants were unusually sensitive to inhibitors in the agarose overlay. In addition to the IBF agarose routinely used (see Appendix), Seakem agarose (Marine Colloids) was employed for plaque assay. A third agarose preparation used in this study was supplied by Dr. W. Yaphe of the Department of Microbiology and Immunology, McGill University. Use of this specially prepared agarose free of 
88.

TABLE 10

Size of Plaques Produced at $37^{\circ} \mathrm{C}$ in Different Cell Lines

Infected with Cocal Virus 48 hr Postinfection

\begin{tabular}{l|c|c|}
\hline \multirow{2}{*}{ Cell Line } & \multicolumn{2}{|c|}{ Virus Pool } \\
\cline { 2 - 3 } & $\begin{array}{c}\text { Normal } \\
\text { Plaque Cocal }\end{array}$ & $\begin{array}{c}\text { Small } \\
\text { Plaque Cocal }\end{array}$ \\
\hline Chick Embryo & $3-5 \mathrm{~mm}$ & $1 \mathrm{~mm}$ or less \\
\hline L Cells & $3-4 \mathrm{~mm}$ & $<1 \mathrm{~mm}$ \\
\hline BHK-21 & $4-6 \mathrm{~mm}$ & $2-4 \mathrm{~mm}$ \\
\hline
\end{tabular}


charged polysaccharides (personal communication, Dr. Yaphe) in the plaque overlay was shown by Russ (1969) to result in larger Mayaro plaques than an overlay containing IBF agarose.

IBF agarose was supplemented with DEAE dextran at a final concentration of $100 \mu \mathrm{g}$ per $\mathrm{ml}$ since certain cations have previously been shown to reverse inhibition of plaque development imposed by agar fractions (Liebhaber and Takemoto, 1961; Miles and Austin, 1963; Brown and Packer, 1964). Bacto agar (Difco) was also employed as overlay to see whether plaque inhibitors were present that might cause further reduction in plaque size if agarose inhibitors are indeed a factor in regulating the size of the small plaque Cocal.

Chick embryo monolayers were infected with normal or sma!l plaque Cocal and plaque overlays were applied containing all of the aforementioned agarose and agar preparations at a final concentration of $0.7 \%$. Plaques obtained after $48 \mathrm{hr}$ incubation at $37^{\circ} \mathrm{C}$ were constant in size irrespective of the overlay added. This would indicate that plaque inhibitors were not a factor in development of the small plaque variant of Cocal.

\section{d) Growth of Small Plaque Virus in L Cells}

$L$ cells were infected with Cocal from normal and small plaque pools and incubated at $30^{\circ} \mathrm{C}$. As observed in Fig. 15, small plaque Cocal replicated to a lower titer than normal plaque Cocal and had a p.f.u. per cell ratio of less than 1. 
Fig. 15. Growth of normal and small plaque Cocal virus in $L$ cells at $30^{\circ} \mathrm{C}$ with an input multiplicity of 0.1 .

$$
\begin{aligned}
& \longrightarrow \text { Cell count } \\
& \longrightarrow \text { Extracellular virus } \\
& \longrightarrow \text { Cell associated virus }
\end{aligned}
$$




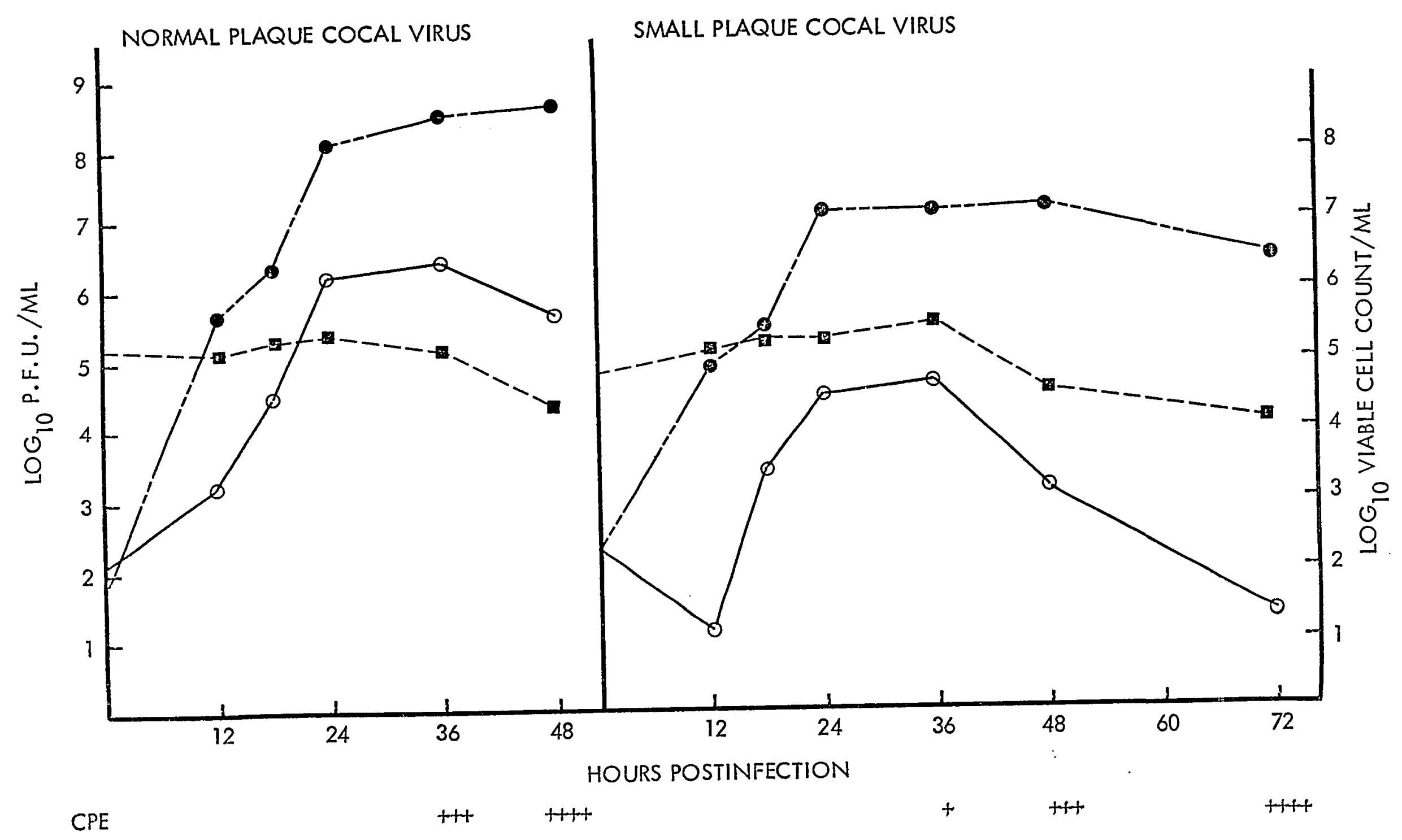


Whereas advanced CPE was observed by $48 \mathrm{hr}$ postinfection in L cells infected with normal plaque Cocal, CPE progressed more slowly in the small plaque virus infection with advanced CPE attained only after $72 \mathrm{hr}$.

e) Growth of Small Plaque Virus in A. albopictus Cells

A. albopictus cells were infected with normal and small plaque Cocal at an input multiplicity of 0.1 and cells were incubated at $30^{\circ} \mathrm{C}$. No apparent difference was observed in the ability of these different strains to multiply in infected cells as shown in Fig. 16. Small plaque Cocal multiplied readily in A. albopictus and all virus recovered on chick embryo retained the small plaque characteristic.

f) Virulence of Small Plaque Virus

Small plaque variants were shown previously to possess decreased virulence for adult mice (see Section D.4.) compared to normal plaque Cocal. Further studies were undertaken with the small plaque pool grown in chick embryo.

Adult mice were inoculated i.c. with 180 p.f.u. of normal plaque and with 180, 1800, and 18,000 p.f.u. of small plaque Cocal virus. The results are presented in Table 11. Whereas 100\% mortality occurred in mice challenged with 180 p.f.u. of normal plaque Cocal virus, mice challenged with 180, 1800, and 18,000 p.f.u. of small plaque Cocal virus showed mortalities of only 15.4, 
Fig. 16. Growth of normal and small plaque Cocal virus in A. albopictus cells at $30^{\circ} \mathrm{C}$ with an input multiplicity of 0.1 .

$\longrightarrow$ Cell count

$\triangle \longrightarrow$ Extracellular virus

$\longrightarrow$ Cell associated virus 


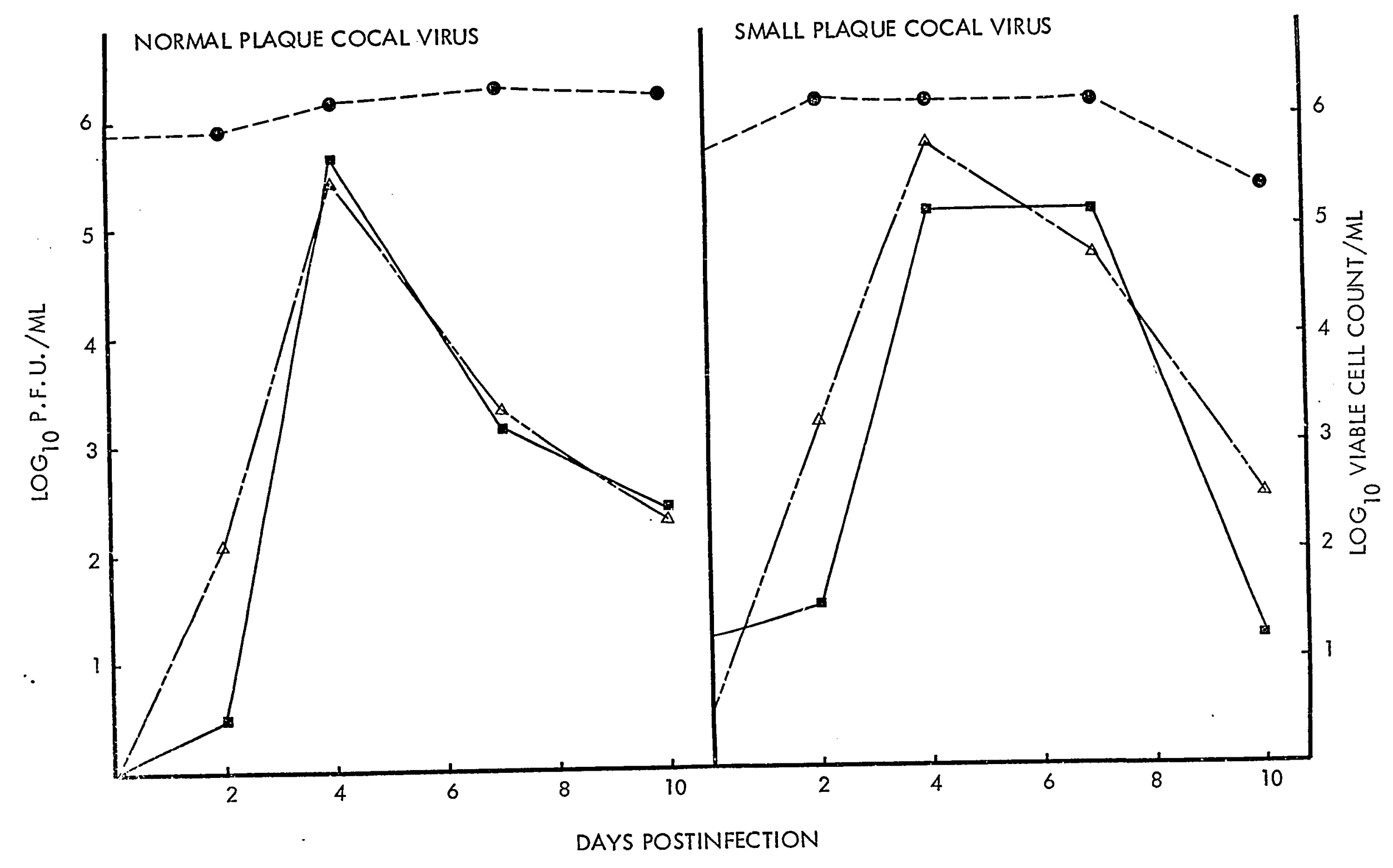


TABLE 11

Intracerebral Challenge of Adult Mice with Normal and Small Plaque Cocal

a)

\begin{tabular}{|c|c|c|c|c|}
\hline Viru & Dose Inoculated & Mice Killed/ & Per Cent & Survivors \\
\hline $\begin{array}{l}\text { Normal } \\
\text { Ploque }\end{array}$ & $\begin{array}{c}180 \text { p.f.u./ } \\
\text { mouse }\end{array}$ & $8 / 8$ & 100 & - \\
\hline & $\begin{array}{c}180 \text { p.f.u./ } \\
\text { mouse }\end{array}$ & $2 / 13$ & 15.4 & $7 / 11$ \\
\hline $\begin{array}{l}\text { Small } \\
\text { Plaque }\end{array}$ & $\begin{array}{c}1800 \text { p.f.u./ } \\
\text { mouse }\end{array}$ & $1 / 6$ & 16.7 & $0 / 5$ \\
\hline & $\begin{array}{c}18000 \text { p.f.u./ } \\
\text { mouse }\end{array}$ & $3 / 13$ & 23.1 & $2 / 10$ \\
\hline
\end{tabular}

b) Challenge All Survivors with 180 p.f.u./Mouse of Normal Plaque Cocal

\begin{tabular}{|c|c|c|}
\hline Immunizing Dose & $\begin{array}{c}\text { Survivors } \\
\text { Challenged }\end{array}$ & Mortalities \\
\hline 180 p.f.u./mouse & 7 & 1 \\
1800 p.f.u./mouse & 4 & 1 \\
18000 p.f.u./mouse & 6 & 1 \\
\hline
\end{tabular}


16.7 , and $23.1 \%$, respectively. However, numerous surviving mice showed paralysis of one or both hind legs indicating a predilection of attenuated virus for the spinal cord.

All surviving mice were challenged with 180 p.f.u. of normal plaque Cocal and most mice survived (see Table 11). Thus, small plaque Cocal virus had apparently multiplied to some extent in mice that survived initial virus challenge.

\section{E. NATURE OF RESISTANCE OF A. ALBOPICTUS TO COCAL VIRUS \\ 1. Incubation of Cells at 30 and $37^{\circ} \mathrm{C}$}

A. albopictus cells infected with an input multiplicity of 10 were incubated at $37^{\circ} \mathrm{C}$ for 12 and $24 \mathrm{hr}$ and transferred to $30^{\circ} \mathrm{C}$ for further incubation. Results are presented in Table 12. Cells incubated at $37^{\circ} \mathrm{C}$ for varying times and transferred to $30^{\circ} \mathrm{C}$ did not yield greater virus titers after 2 and 4 days postinfection than cells incubated at $30^{\circ} \mathrm{C}$ for the entire period. Therefore, it appears that continued incubation of infected cells at $37^{\circ} \mathrm{C}$ is required for substantial increase in virus titer.

2. Superinfection of Persistently Infected Cells

a) Superinfection with Homologous Virus

A. albopictus $c . c \cdot 5$-passage 30 persistently infected cells were super- 
TABLE 12

Effect of Transfer of Infected Cells from 37 to $30^{\circ} \mathrm{C}$ on Virus Titer in A. albopictus

\begin{tabular}{|c|c|c|c|c|c|}
\hline \multicolumn{2}{|c|}{ Days Postinfection } & $30^{\circ} \mathrm{C}$ & $\begin{array}{l}37^{\circ} \mathrm{C} \text { for } 12 \mathrm{hr}- \\
\text { Transfer to } 30^{\circ} \mathrm{C}\end{array}$ & $\begin{array}{l}37^{\circ} \mathrm{C} \text { for } 24 \mathrm{hr}- \\
\text { Transfer to } 30^{\circ} \mathrm{C}\end{array}$ & $37^{\circ} \mathrm{C}$ \\
\hline \multirow{3}{*}{ Day 2} & Total Cells/Bottle & $2.0 \times 10^{6}$ & $3.4 \times 10^{6}$ & $1.4 \times 10^{6}$ & $1.4 \times 10^{6}$ \\
\hline & $\begin{array}{l}\text { Virus Yield } \\
(p . f . u \cdot / \mathrm{ml})\end{array}$ & $2.2 \times 10^{5}$ & $1.6 \times 10^{5}$ & $2.5 \times 10^{5}$ & $3.5 \times 10^{7}$ \\
\hline & p.f.u./Cell & 0.11 & 0.047 & 0.18 & 25.0 \\
\hline \multirow{3}{*}{ Day 4} & Total Cells/Bottle & $3.9 \times 10^{6}$ & $8.7 \times 10^{6}$ & $3.7 \times 10^{6}$ & $1.5 \times 10^{6}$ \\
\hline & $\begin{array}{l}\text { Virus Yield } \\
(p . f . u \cdot / m l)\end{array}$ & $3.4 \times 10^{5}$ & $1.4 \times 10^{5}$ & $1.0 \times 10^{5}$ & $1.5 \times 10^{5}$ \\
\hline & p.f.u./Cell & 0.09 & 0.09 & 0.03 & 0.1 \\
\hline
\end{tabular}


infected with Cocal virus at an input multiplicity of 10. Also, A. albopictus c.c. 6 -passage 30 cells that have lost virus ("cured" culture - see Section D.1.) were superinfected with Cocal as well as $\underline{A}$. albopictus cells not previously infected with Cocal virus. Infected cultures were incubated at 30 and $37^{\circ} \mathrm{C}$. Results for superinfection at $30^{\circ} \mathrm{C}$ are presented in Fig. 17.

Superinfection of persistently infected cells with Cocal virus yielded no enhanced virus titers compared to non-superinfected controls. Interestingly, incubation at $37^{\circ} \mathrm{C}$ did not increase titers of persistently infected cells nor of superinfected cultures.

Superinfection of "cured" cultures revealed that although virus adsorbed to cells at a rate comparable to control cultures, the cells were resistant to Cocal and virus was eliminated from infected cultures. Loss of virus from "cured" cultures

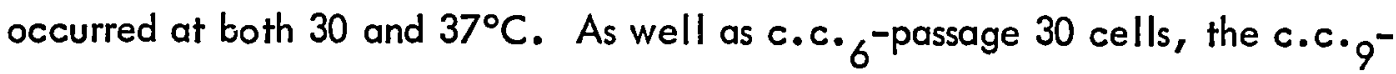
passage 20 "cured" culture (see Table 9) was also resistant to Cocal superinfection.

\section{b) Superinfection with Unrelated Arboviruses}

A. albopictus control, persistently infected, and "cured" cultures were superinfected with 3 viruses unrelated to Cocal. These included Flanders (rhabdovirus), Mayaro (group A), and Nepuyo (group C) arboviruses. Due to differing virus titers of stock pools, cells were infected with input multiplicities of 0.001 , 0.01 , and 10 for Nepuyo, Flanders, and Mayaro viruses, respectively. All infected 
Fig. 17. Cocal virus superinfection of $\underline{A}$. albopictus cells persistently infected with Cocal virus at $30^{\circ} \mathrm{C}$.

\author{
$\odot$ Persistent virus titer \\ $-\longrightarrow$ Superinfection with Cocal virus
}




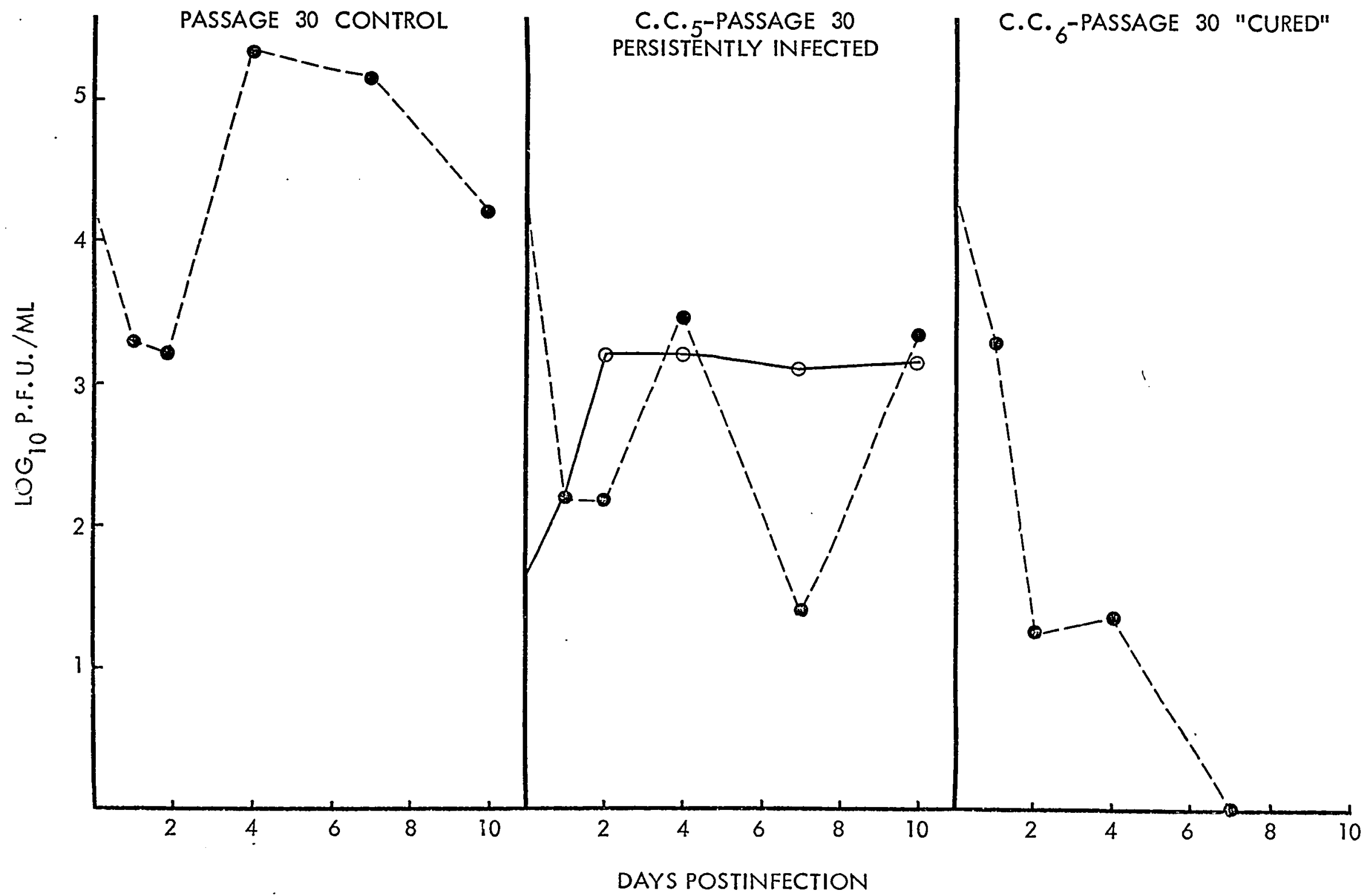

$:$ 
cultures were incubated at $30^{\circ} \mathrm{C}$. Results are presented in Fig. $18-20$.

All viruses were found to multiply in $\underline{A}$. albopictus cells producing the familiar non-cytolytic infection characteristic of arbovirus infection of mosquito cells. Control cultures infected with Mayaro virus yielded titers ( $10^{7}$ p.f.u. per ml) much higher than cultures infected with Flanders or Nepuyo virus.

All A. albopictus cells persistently infected with Cocal virus were superinfected with unrelated arboviruses to a level equivalent to infected controls. Interestingly, A. albopictus "cured" cells although resistant to superinfection with Coc,al supported growth of unrelated arboviruses to a level approx. equivalent to control cells except for Mayaro virus which produced titers $1-2$ logs lower than the control.

3. Antiviral Factors in Mosquito Tissue Culture Medium

a) Survival of Virus in Different Media

Tests for direct antiviral activity of tissue culture media were undertaken by incubating Cocal virus in MM 97-3 and Maintenance Medium No. 3 (Gibco) at $30^{\circ} \mathrm{C}$. Results are presented in Table 13.

Cocal virus was found to decline less than $1 \log$ in titer after $24 \mathrm{hr}$ incubation at $30^{\circ} \mathrm{C}$ with slightly increased virus survival in Maintenance Medium No. 3. However, it must be concluded that neither tissue culture medium possessed any significant virucidal property. 
Fig. 18. Flanders virus superinfection of $\underline{A}$. albopictus cells persistently infected with Cocal virus at $30^{\circ} \mathrm{C}$.

$$
\begin{aligned}
& \longrightarrow+-\ldots \text { Flanders virus }\left(L_{50} / 0.02 \mathrm{ml}\right) \\
& \longrightarrow \text { Cocal virus (p.f.u./ml) }
\end{aligned}
$$




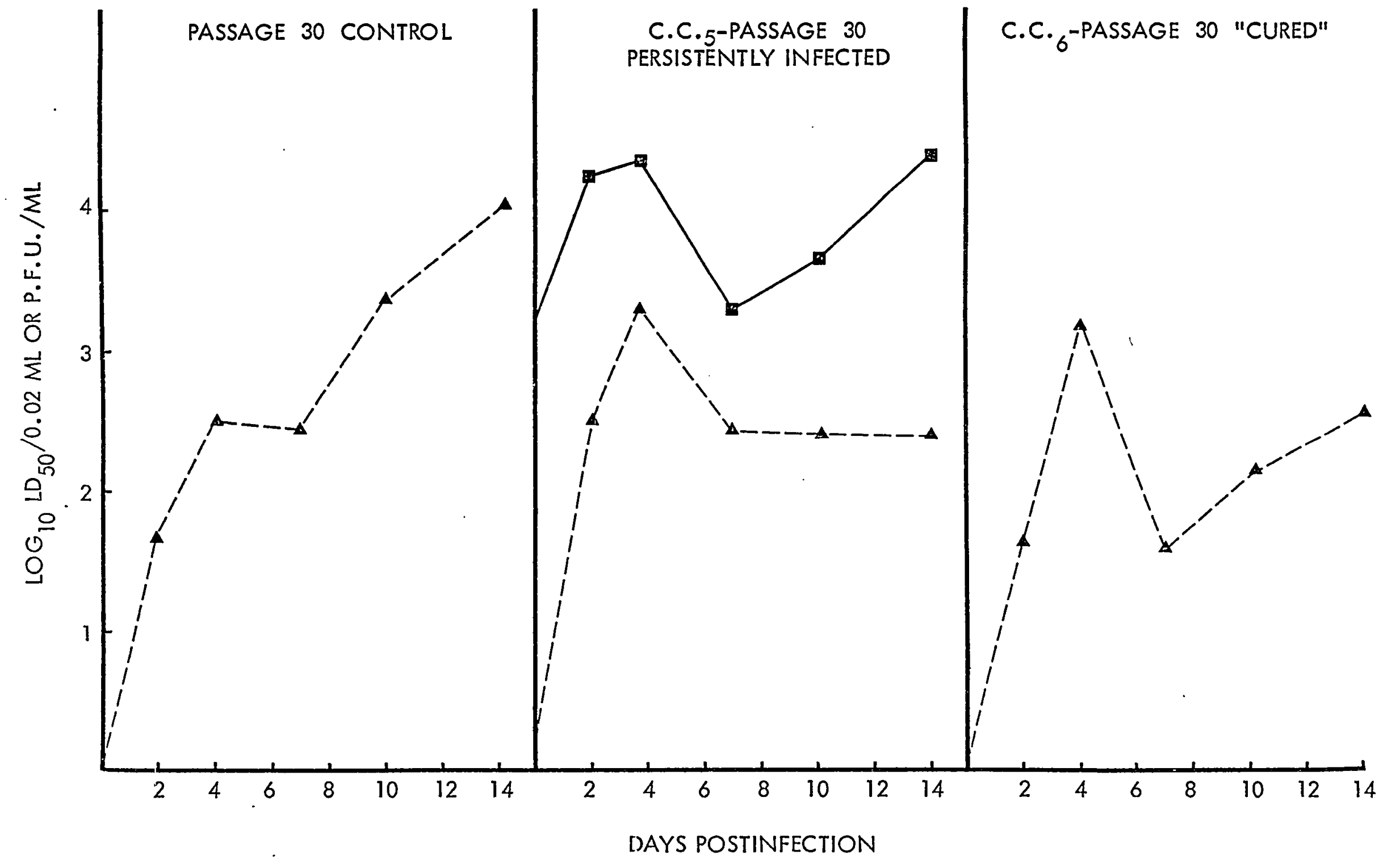


Fig. 19. Mayaro virus superinfection of $\underline{A}$. albopictus cells persistently infected with Cocal virus at $30^{\circ} \mathrm{C}$.

$$
\begin{aligned}
& - \text { Mayaro virus } \\
& \text { Cocal virus }
\end{aligned}
$$




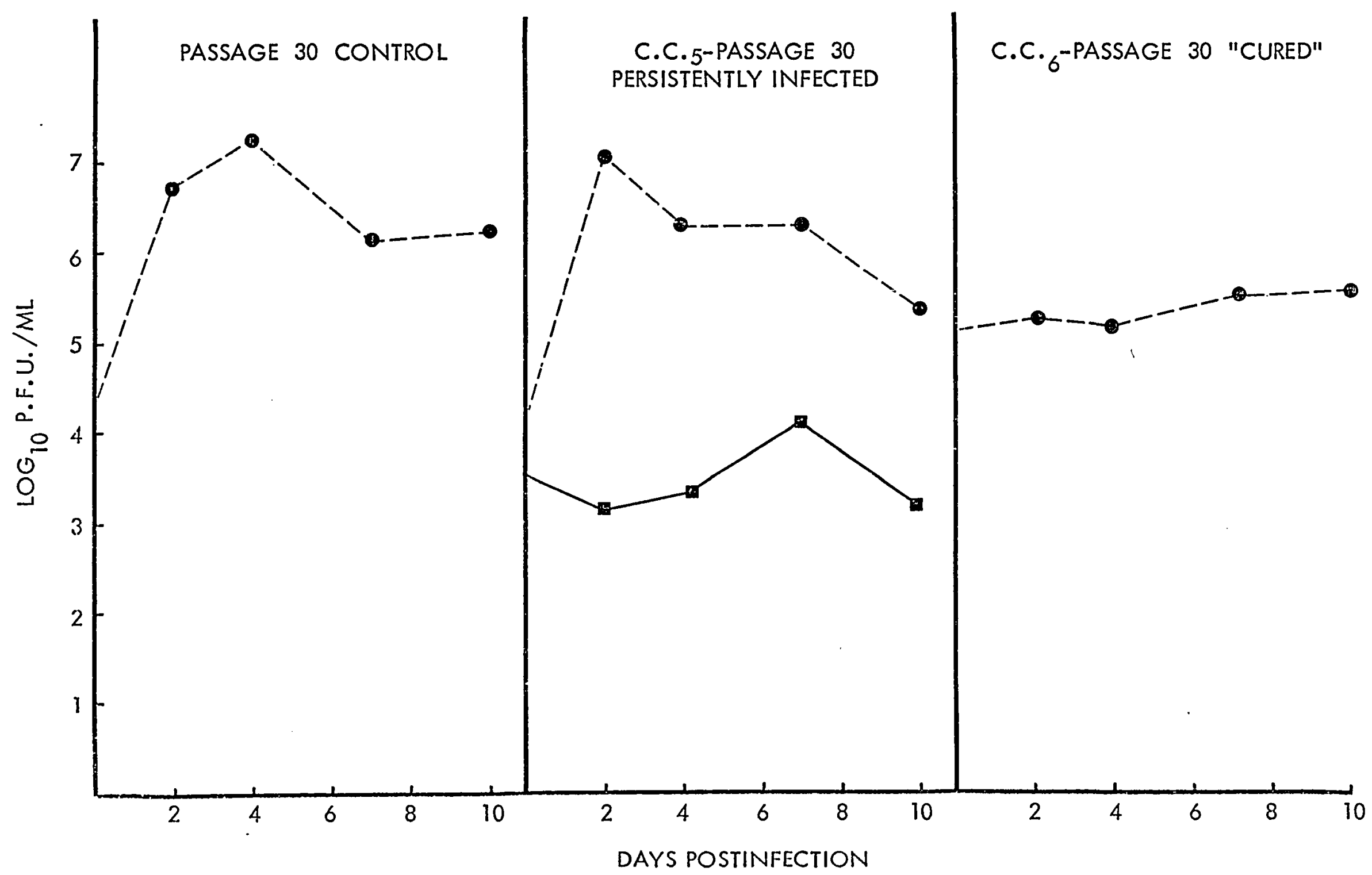


Fig. 20. Nepuyo virus superinfection of $\underline{A}$. albopictus cells persistently infected with Cocal virus at $30^{\circ} \mathrm{C}$.

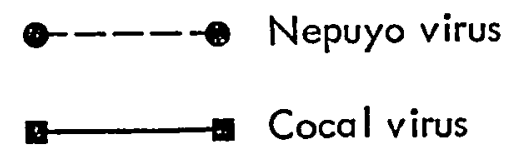




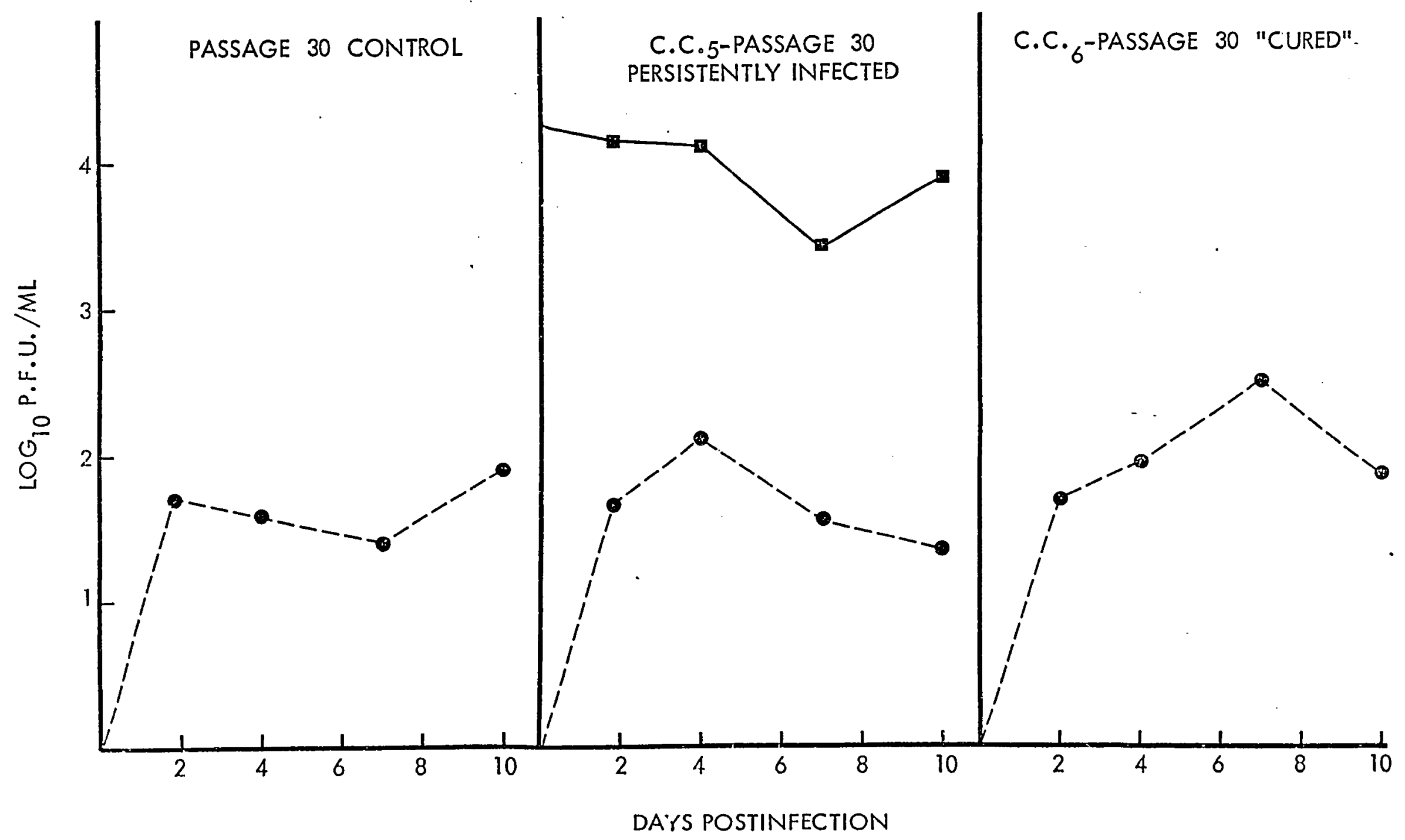

$\overrightarrow{0}$ 
102.

TABLE 13

Survival of Virus in Tissue Culture Maintenance Media at $30^{\circ} \mathrm{C}$

\begin{tabular}{|c|c|c|}
\hline Incubation Period & $\begin{array}{c}\text { Maintenance } \\
\text { Medium No. 3* }\end{array}$ & $\begin{array}{c}\text { Mosquito Maintenance } \\
\text { Medium (MM 97-3) }\end{array}$ \\
\hline $6 \mathrm{hr}$ & $3.8 \times 10^{4}$ & $1.5 \times 10^{4}$ \\
\hline $12 \mathrm{hr}$ & $1.8 \times 10^{4}$ & $1.3 \times 10^{4}$ \\
\hline $24 \mathrm{hr}$ & $7.5 \times 10^{3}$ & $3.2 \times 10^{3}$ \\
\hline
\end{tabular}

* Gibco

b) Virus Titer in Cells under Different Media

Comparisons were made of virus titers produced by $\underline{A}$. albopictus maintained under M 199 (Gibco) and MM 97-3. Cells remained viable for 10 days under M 199 but virus production was slightly lower than in cells maintained under MM 97-3.

The purpose of this experiment was to determine whether antiviral factors were present in MM 97-3 which inhibited virus spread to neighbouring cells. Since infected $L$ cells yield high virus titers under $M 199$, this medium was used as a control. Attempts to increase virus titers in cells under M 199 were unsuccessful, but 
only limited conclusions can be drawn since the metabolism of A. albopictus cells may have been impaired by this new medium.

\section{Assays for Interferon Production by Mosquito Cells}

Attempts were undertaken to assay for interferon production by Cocal infected A. albopictus cells. Fluids tested included MM 97-3 removed from persistently infected cells (c.c. $5^{- \text {passage } 30)}$ as well as MM 97-3 removed from cultures of A. albopictus control (previously uninfected) and "cured" cells (c.c. $6^{\text {-passage } 30 \text { ) }}$ infected with an input multiplicity of 10 and incubated at $30^{\circ} \mathrm{C}$ for 2 days. Control fluid from uninfected A. albopictus maintained under MM 97-3 was also sampled. Virus was removed from test fluids by ultracentrifugation as per Cocal chick embryo concentrated pool (see Section III.B.1.) and by subsequent treatment of fluids with diluted Cocal immune serum:

Confluent A. albopictus monolayers were exposed to test fluids for $12 \mathrm{hr}$ at $30^{\circ} \mathrm{C}$, washed three times with PBS to remove immune serum, and challenged with Cocal virus (input multiplicity of 10). Growth sampling was done as per usual on days 1, 2, and 4 postinfection. Results are presented in Table 14.

No evidence was found for interferon production by this crude assay. 
TABLE 14

Interferon Assays in A. albopictus

\begin{tabular}{|c|c|c|c|c|c|}
\hline \multirow{2}{*}{\multicolumn{2}{|c|}{$\begin{array}{l}\text { Post-Treatment } \\
\text { Sampling }\end{array}$}} & \multicolumn{4}{|c|}{ MM 97-3 Harvested from } \\
\hline & & Control Cells & $\begin{array}{c}\text { Control Cells } \\
+ \\
\text { Cocal }\end{array}$ & $\begin{array}{l}\text { c.c. } 5^{-P 30 *} \\
\text { Persistently } \\
\text { Infected Cells }\end{array}$ & $\begin{array}{l}\text { c.c.6-P30* } \\
\text { "Cured" Cells } \\
+ \text { Cocal }\end{array}$ \\
\hline Day 1 & $\begin{array}{l}\text { Virus Yield } \\
\text { (p.f.u./ml) }\end{array}$ & $6.1 \times 10^{4}$ & $1.4 \times 10^{5}$ & $8.8 \times 10^{4}$ & $8.1 \times 10^{4}$ \\
\hline Day 2 & $\begin{array}{l}\text { Virus Yield } \\
(\text { p.f.u./ml) }\end{array}$ & $7.6 \times 10^{5}$ & $1.8 \times 10^{6}$ & $2.5 \times 10^{5}$ & $1.5 \times 10^{5}$ \\
\hline Day 4 & $\begin{array}{l}\text { Virus Yield } \\
\text { (p.f.u./ml) }\end{array}$ & $1.2 \times 10^{6}$ & $1.8 \times 10^{6}$ & $1.4 \times 10^{6}$ & $4.0 \times 10^{5}$ \\
\hline
\end{tabular}

* $\mathrm{P} 30=$ passage 30 
105.

\section{Effect of Inhibitors on Virus Titer}

a) Actinomycin D

The effect of actinomycin D (Sigma) on Cocal infection of $\underline{A}$. albopictus

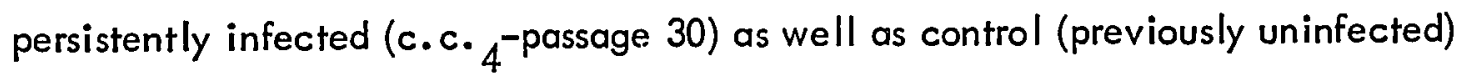
and "cured" (c.c. 6 -passage 30) cultures infected at an input multiplicity of 10 was studied. Actinomycin, diluted in MM 97-3, was added to infected monolayers and cells were incubated at $30^{\circ} \mathrm{C}$. The results are presented in Table 15.

Actinomycin D had little effect on increasing titers of control and "cured" cultures infected with Cocal. However, virus titers were increased by up to 2 logs in persistently infected cells exposed to actinomycin. As shown in Fig. 21, titers in persistently infected cells were found to increase by $1 \mathrm{log}$ as early as $6 \mathrm{hr}$ post actinomycin exposure. The p.f.u. per cell ratio was much higher than in untreated cultures and in occasional samplings (see Tabie 15) exceeded 1.0.

\section{b) Puromycin}

Puromycin dihydrochloride (Nutritional Biochemicals) was diluted to concentrations of 6 to $100 \mu \mathrm{g}$ per $\mathrm{ml}$ in MM 97-3 and added to confluent monolayers of A. albopictus persistently infected cells (c.c. ${ }_{5}$-passage 30 ) with subsequent incubation at $30^{\circ} \mathrm{C}$. Results are presented in Table 16.

No enhancement of virus titers was observed in the puromycin treated persistently infected cells. 
TABLE 15.

Effect of Actinomycin D on Virus Titer in A. albopictus Cells

\begin{tabular}{|c|c|c|c|c|c|c|c|c|c|}
\hline & \multirow{2}{*}{$\begin{array}{l}\text { Post-Treatment } \\
\text { Sampling }\end{array}$} & \multicolumn{3}{|c|}{ Initially Infected Cells } & \multicolumn{3}{|c|}{$\begin{array}{c}\text { C.c. } 4-\mathrm{P} 30^{*} \\
\text { Persistently Infected Cells }\end{array}$} & \multicolumn{2}{|c|}{$\begin{array}{c}\text { c.c.6-P30 } \\
\text { "Cured" Culture }\end{array}$} \\
\hline & & $0 \mu \mathrm{g} / \mathrm{ml}$ & $0.5 \mu \mathrm{g} / \mathrm{ml}$ & $1.0 \mu \mathrm{g} / \mathrm{ml}$ & $0 \mu \mathrm{g} / \mathrm{ml}$ & $0.5 \mu \mathrm{g} / \mathrm{ml}$ & $1.0 \mu \mathrm{g} / \mathrm{ml}$ & $0 \mu \mathrm{g} / \mathrm{ml}$ & $1.0 \mu \mathrm{g} / \mathrm{ml}$ \\
\hline \multirow{2}{*}{ Day 1} & Total Cells/Bottle & $8.5 \times 10^{5}$ & $8.1 \times 10^{5}$ & $3.9 \times 10^{5}$ & $9.2 \times 10^{5}$ & $8.3 \times 10^{5}$ & $1.1 \times 10^{5}$ & $3.1 \times 10^{6}$ & $1.3 \times 10^{6}$ \\
\hline & $\begin{array}{l}\text { Virus Yield } \\
(p . f . u \cdot / m l)\end{array}$ & $6.5 \times 10^{2}$ & $8.0 \times 10^{2}$ & $1.6 \times 10^{3}$ & $1.9 \times 10^{3}$ & $6.1 \times 10^{4}$ & $1.7 \times 10^{5}$ & $2.0 \times 10^{3}$ & $5.5 \times 10^{2}$ \\
\hline \multirow{2}{*}{ Day 2} & Total Cells/Bottle & $1.2 \times 10^{6}$ & $1.3 \times 10^{6}$ & $2.5 \times 10^{6}$ & $7.6 \times 10^{5}$ & $3.7 \times 10^{6}$ & $8.4 \times 10^{5}$ & $9.8 \times 10^{5}$ & $9.6 \times 10^{5}$ \\
\hline & $\begin{array}{l}\text { Virus Yield } \\
\text { (p.f.u./ml) }\end{array}$ & $2.5 \times 10^{4}$ & $3.3 \times 10^{4}$ & $6.1 \times 10^{4}$ & $1.1 \times 10^{4}$ & $3.3 \times 10^{4}$ & $2.9 \times 10^{4}$ & $8.0 \times 10^{2}$ & $3.0 \times 10^{2}$ \\
\hline \multirow[b]{2}{*}{ Day 4} & Total Celis/Bottle & $2.9 \times 10^{6}$ & $1.1 \times 10^{6}$ & $1.2 \times 10^{6}$ & \multirow[b]{2}{*}{ ND ** } & \multirow[b]{2}{*}{ ND } & \multirow[b]{2}{*}{ ND } & \multirow[b]{2}{*}{ ND } & \multirow[b]{2}{*}{ ND } \\
\hline & $\begin{array}{l}\text { Virus Yield } \\
\text { (p.f.u./ml) }\end{array}$ & $2.1 \times 10^{5}$ & $2.5 \times 10^{5}$ & $9.0 \times 10^{4}$ & & & & & \\
\hline P30 & $=$ pass & & & & & & & & \\
\hline
\end{tabular}


Fig. 21. Effect of actinomycin D on virus titer of A. albopictus persistently infected cells at $30^{\circ} \mathrm{C}$.

$$
\longrightarrow \text { Cell count }
$$




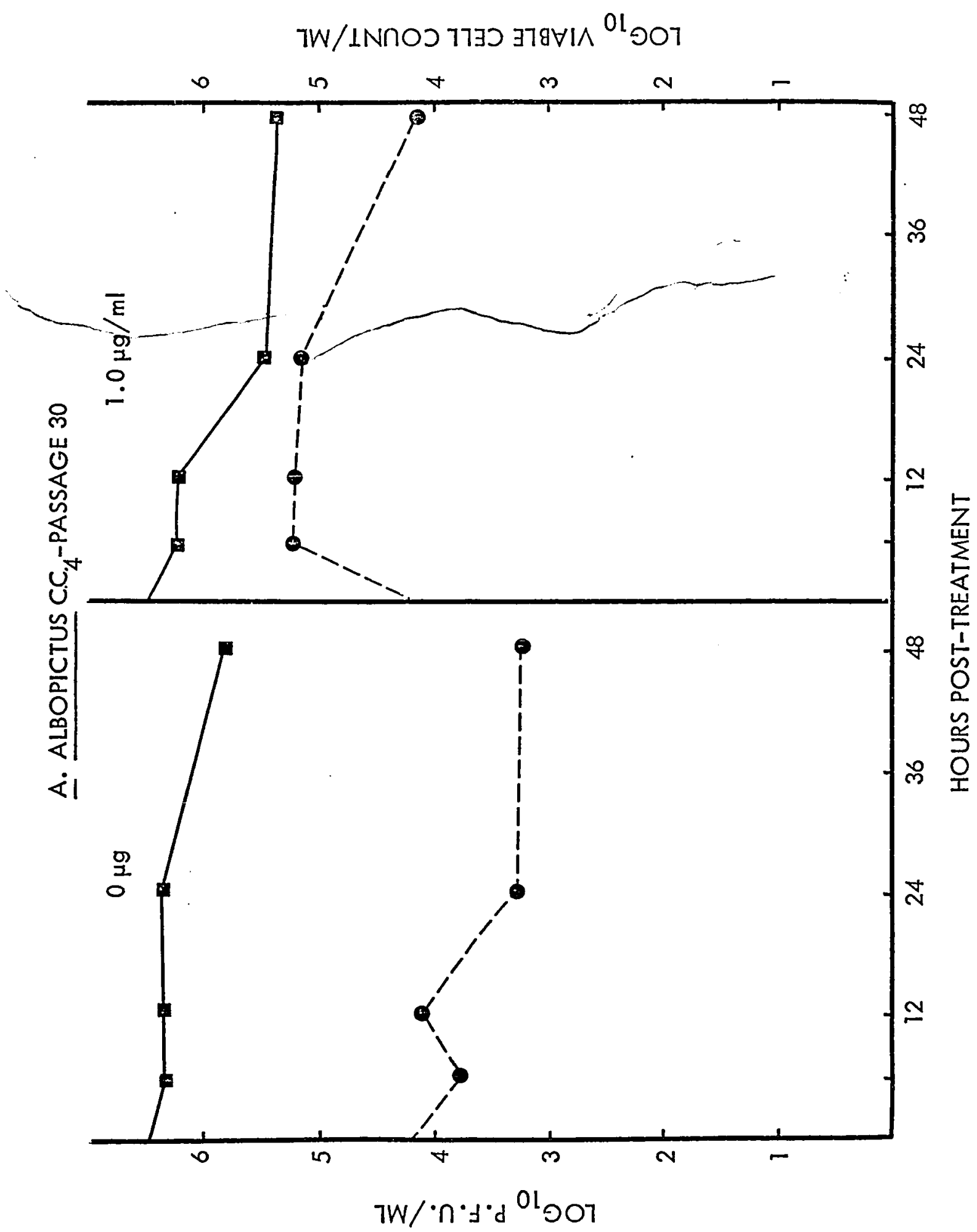


TABLE 16

Effect of Puromycin on Titer of A. albopictus Persistently Infected Cells

\begin{tabular}{|c|c|c|c|c|c|c|c|}
\hline & \multirow{2}{*}{$\begin{array}{l}\text { Post-Treatment } \\
\text { Sampling }\end{array}$} & \multicolumn{6}{|c|}{ Puromycin Concentration $(\mu \mathrm{g} / \mathrm{ml})$} \\
\hline & & 0 & 6 & 12 & 25 & 50 & 100 \\
\hline \multirow[b]{2}{*}{$6 \mathrm{hr}$} & Total Cells/Bottle & $2.0 \times 10^{6}$ & $1.8 \times 10^{6}$ & $1.8 \times 10^{6}$ & $1.7 \times 10^{6}$ & $2.3 \times 10^{6}$ & $2.0 \times 10^{6}$ \\
\hline & $\begin{array}{l}\text { Virus Yield } \\
\text { (p.f.u./ml) }\end{array}$ & $2.5 \times 10^{3}$ & $1.1 \times 10^{3}$ & $5.3 \times 10^{3}$ & $1.5 \times 10^{3}$ & $7.9 \times 10^{2}$ & $1.1 \times 10^{3}$ \\
\hline \multirow[b]{2}{*}{$12 \mathrm{hr}$} & Total Cells/Bottle & $1.9 \times 10^{6}$ & $2.3 \times 10^{6}$ & $3.0 \times 10^{6}$ & $4.7 \times 10^{5}$ & $2.5 \times 10^{5}$ & $3.4 \times 10^{5}$ \\
\hline & $\begin{array}{l}\text { Virus Yield } \\
\text { (p.f.u./ml) }\end{array}$ & $4.5 \times 10^{3}$ & $8.1 \times 10^{3}$ & $1.1 \times 10^{4}$ & $9.0 \times 10^{2}$ & $9.0 \times 10^{2}$ & $7.9 \times 10^{2}$ \\
\hline \multirow[b]{2}{*}{$24 \mathrm{hr}$} & Total Cells/Bottle & $2.1 \times 10^{6}$ & $2.3 \times 10^{6}$ & $1.4 \times 10^{6}$ & $3.4 \times 10^{5}$ & $3.6 \times 10^{5}$ & $3.5 \times 10^{5}$ \\
\hline & $\begin{array}{l}\text { Virus Yield } \\
\text { (p.f.u./ml) }\end{array}$ & $5.3 \times 10^{3}$ & $4.1 \times 10^{3}$ & $1.2 \times 10^{4}$ & $1.6 \times 10^{3}$ & $8.5 \times 10^{2}$ & $1.2 \times 10^{3}$ \\
\hline
\end{tabular}




\section{F. ELECTRON MICROSCOPY}

\section{L Cells}

a) Viral Contaminant of LCells

Thin sections of uninfected clone $929 \mathrm{~L}$ cells revealed that the cells were contaminated with type $C$ viral particles as shown in Fig. 22.

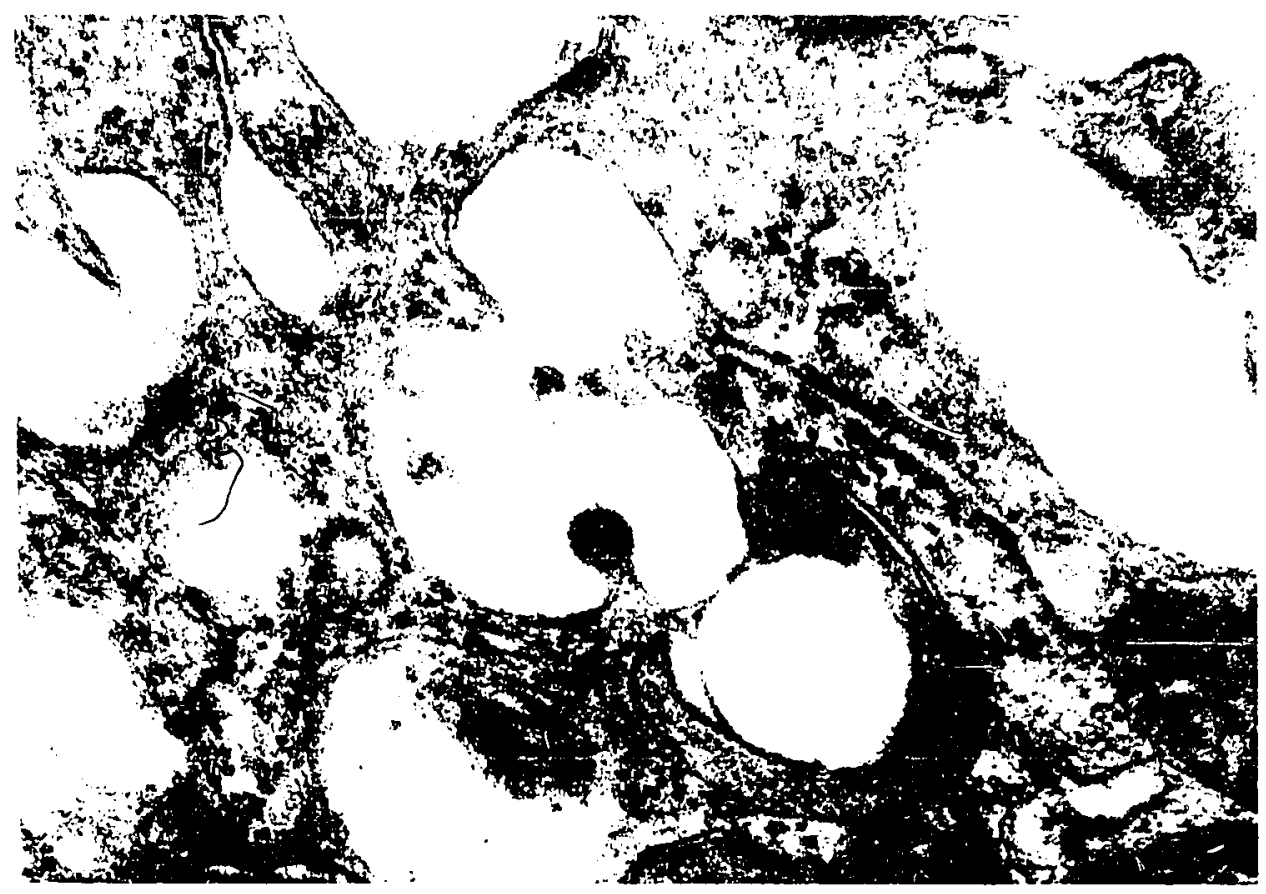

Fig. 22.

Viral contaminant of L 929 cell line.

Magnification 200,000 x. 


\section{F. ELECTRON MICROSCOPY}

\section{1. $\underline{\text { L Cells }}$}

a) Viral Contaminant of LCells

Thin sections of uninfected clone $929 \mathrm{~L}$ cells revealed that the cells were contaminated with type $C$ viral particles as shown in Fig. 22.

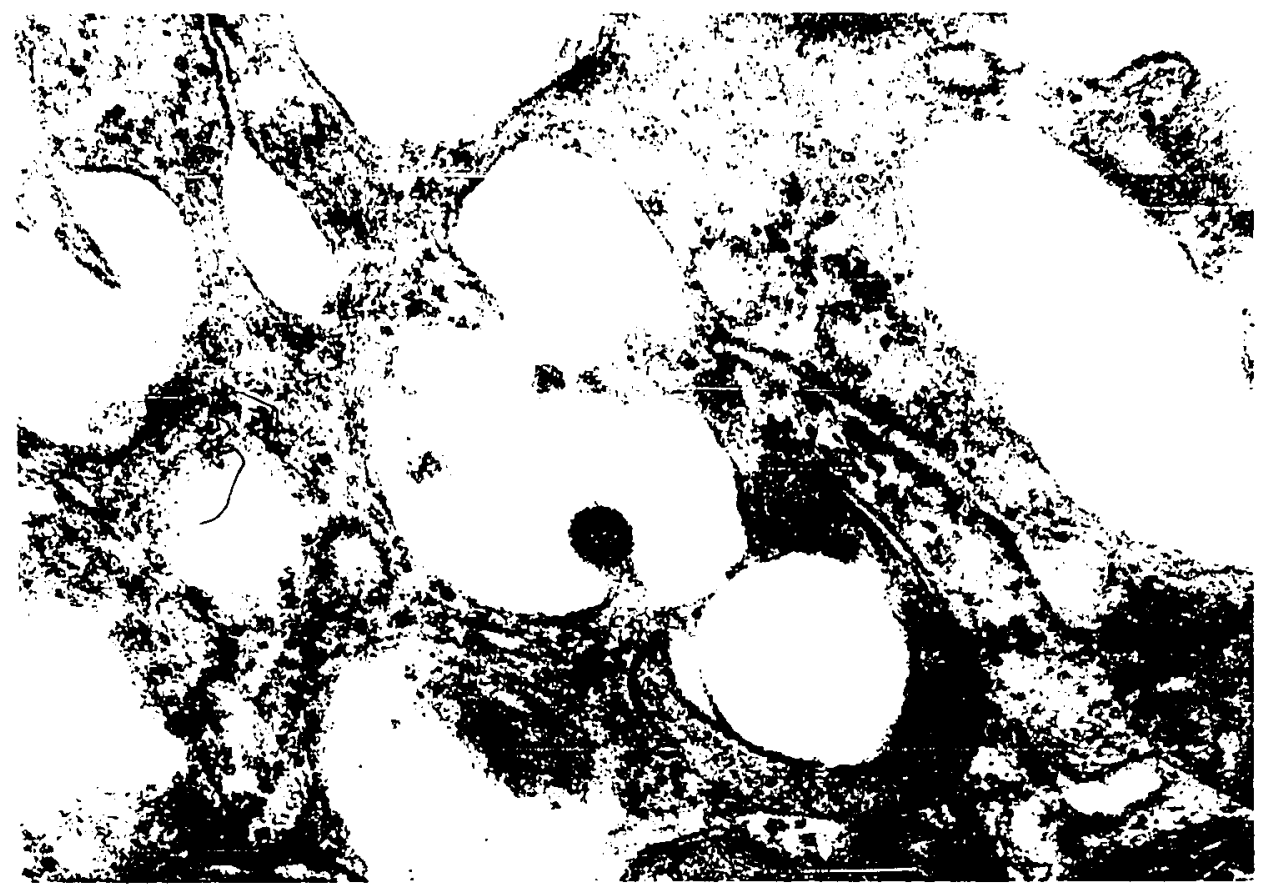

Fig. 22.

Viral contaminant of $L 929$ cell line.

Magnification 200,000 x. 
The presence of such contaminating particles in L cells has been reported previously (Dales and Howatson, 1961; Kindig and Kirsien, 1967; Cromack, 1968; Anderson and Doane, 1972) and is confirmed in this thesis because Anderson and Doane (1972) have noted that, despite previous reports, many virologists are still unaware of the presence of such contaminating viruses. Ignorance of viral contaminants could lead to misinterpretations in studies of virus development in L cells.

b) Cocal Infection of LCells

Representative micrographs from studies on the development of Cocal virus in L cells at $30^{\circ} \mathrm{C}$ are presented in Fig. $23-25$. These studies revealed that the primary site of virus maturation was at the plasma membrane of infected cells. However, virus was also observed, on rare occasions, in intracytoplasmic vacuoles as shown in Fig. 24 b. Virus was never observed in nuclei of infected cells nor were intracytoplasmic crystals ever observed. These studies indicated that Cocal virus matures in L cells in a manner identical to other VSV strains reported previously (Howatson and Whitmore, 1962; Zee et al., 1970).

\section{Cocal Infection of A. albopictus Cells}

Studies on the development of Cocal virus in A. albopictus cells were performed primarily at $37^{\circ} \mathrm{C}$, and, unless otherwise noted, all micrographs presented in Fig. $26-31$ are from cells incubated at this temperature. 
Fig. 23. Cocal virus budding from plasma membrane of an infected L cell. Magnification 15,000 x. 


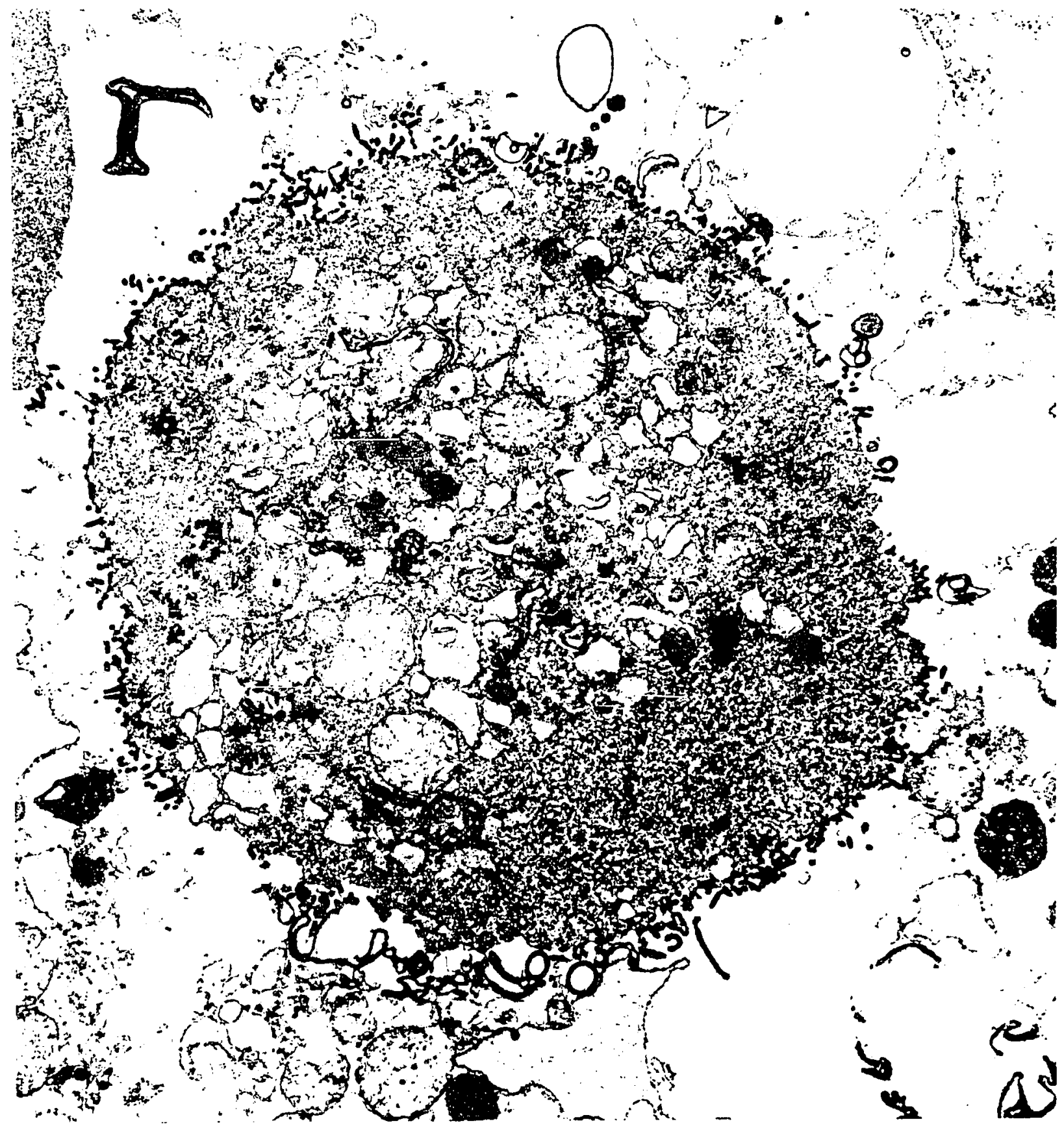


Fig. 24. Cocal virus maturation in L cells. Magnification $80,000 \times$.
a) Plasma membrane
b) Intracytoplasmic vacuole 


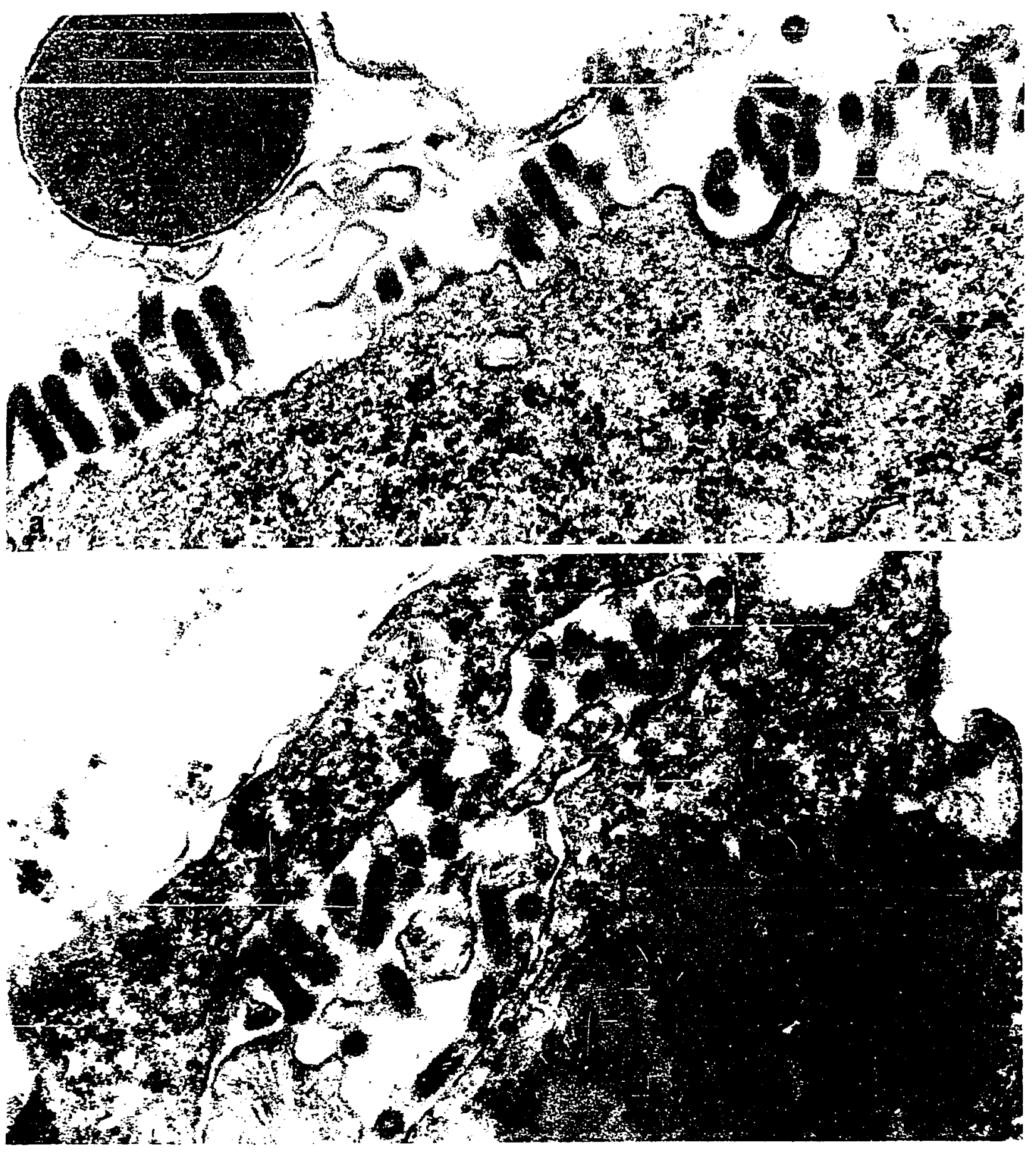


Fig. 25. Budding of Cocal virus from infected $L$ cells. Magnification $120,000 x$.
a to c) Different stages of virus budding
d) Tandem budding 


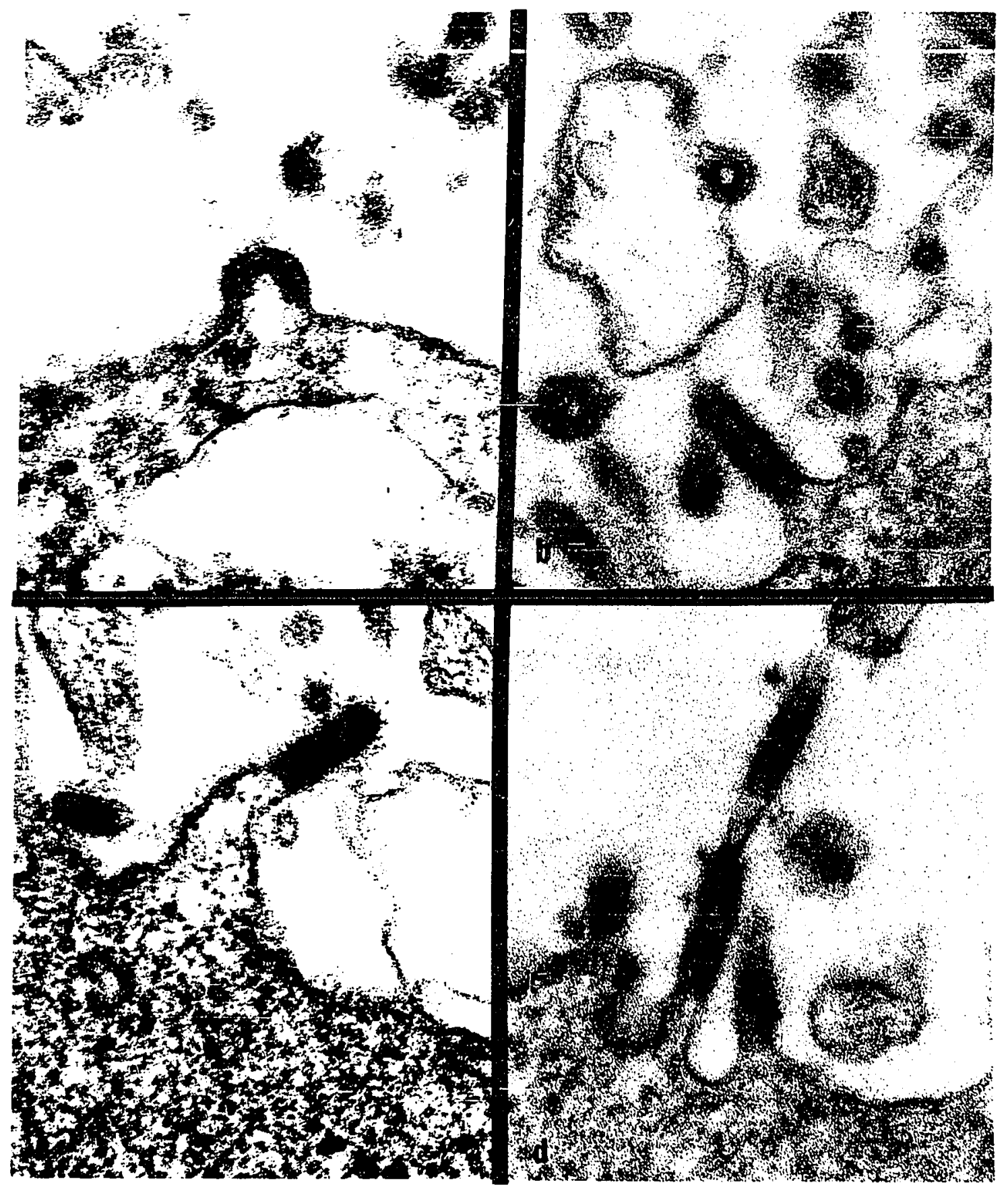


Fig. 26. Cross section of A. albopictus cell infected with Cocal virus. Magnification $15,000 \mathrm{x}$.

$$
\begin{aligned}
& M=\text { Mitochondria } \\
& N=\text { Nucleus } \\
& V=\text { Virus }
\end{aligned}
$$




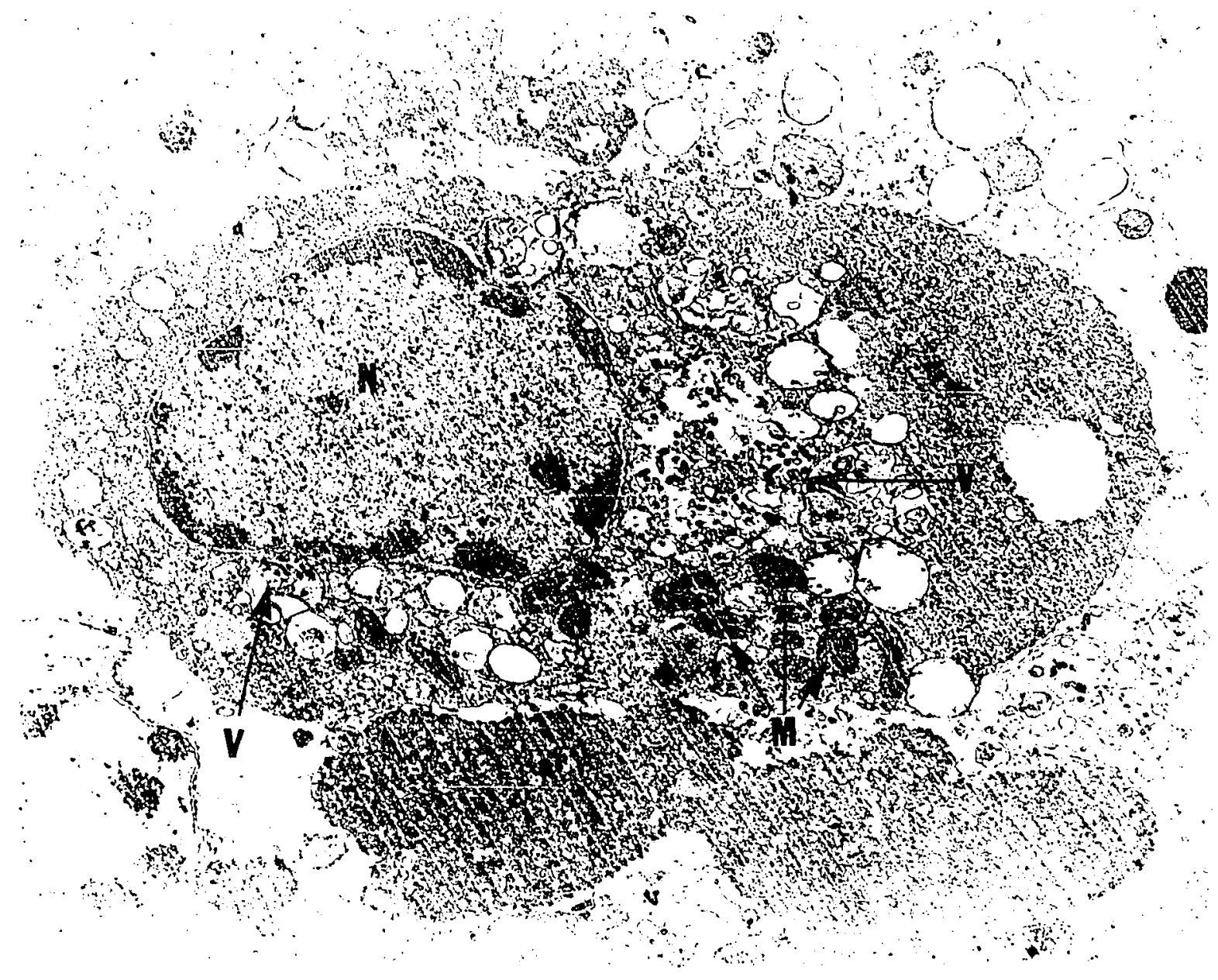


Fig. 27. Cocal virus in intracytoplasmic vesicle of $\underline{A}$. albopictus cell. Magnification $40,000 \times$. 
115.

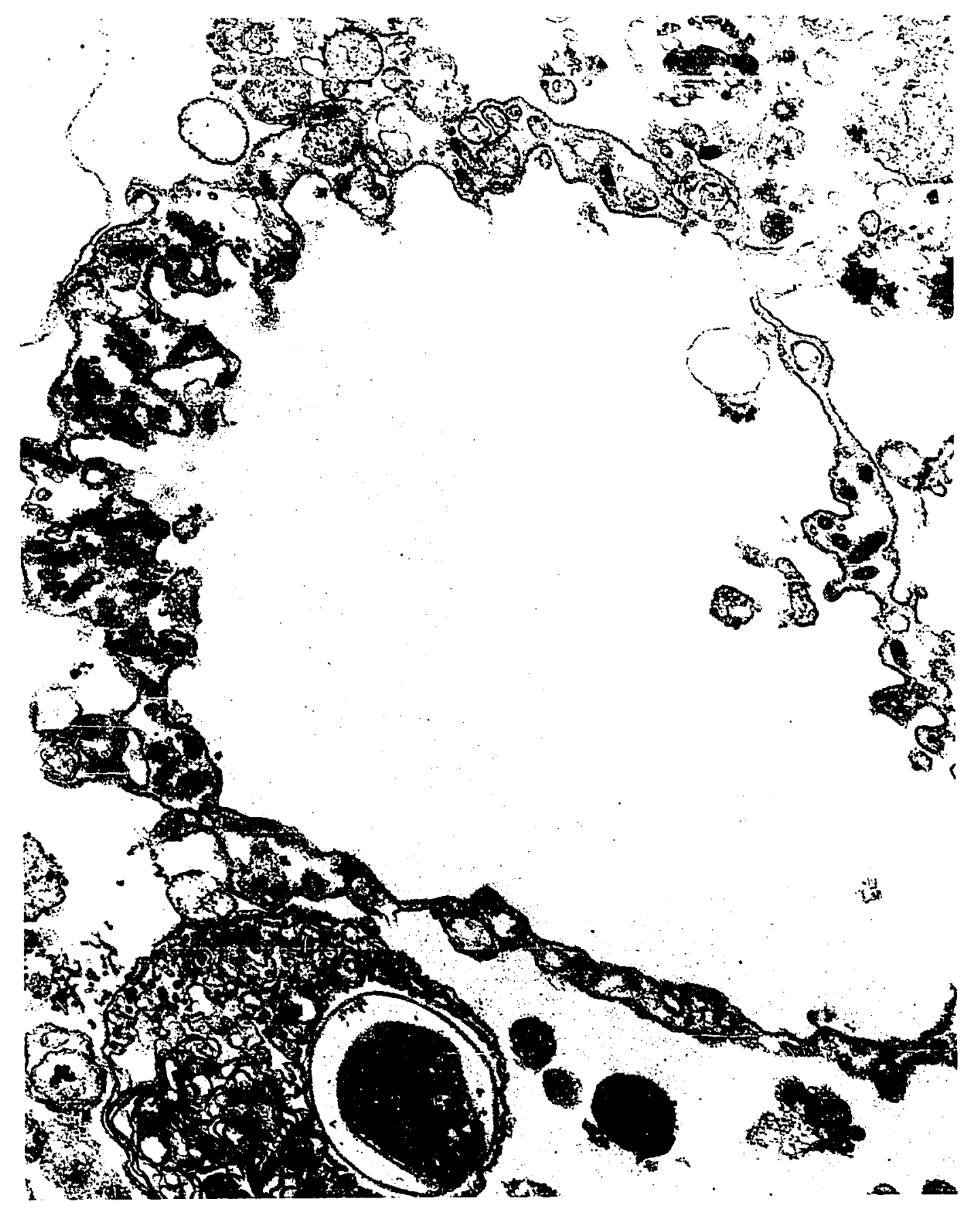


Fig. 28. Cocal virus in intracytoplasmic vesicles of $\underline{A}$. albopictus cells. Magnification $40,000 x$.

a) Cells infected at $30^{\circ} \mathrm{C}$

b) Cells infected at $37^{\circ} \mathrm{C}$ 


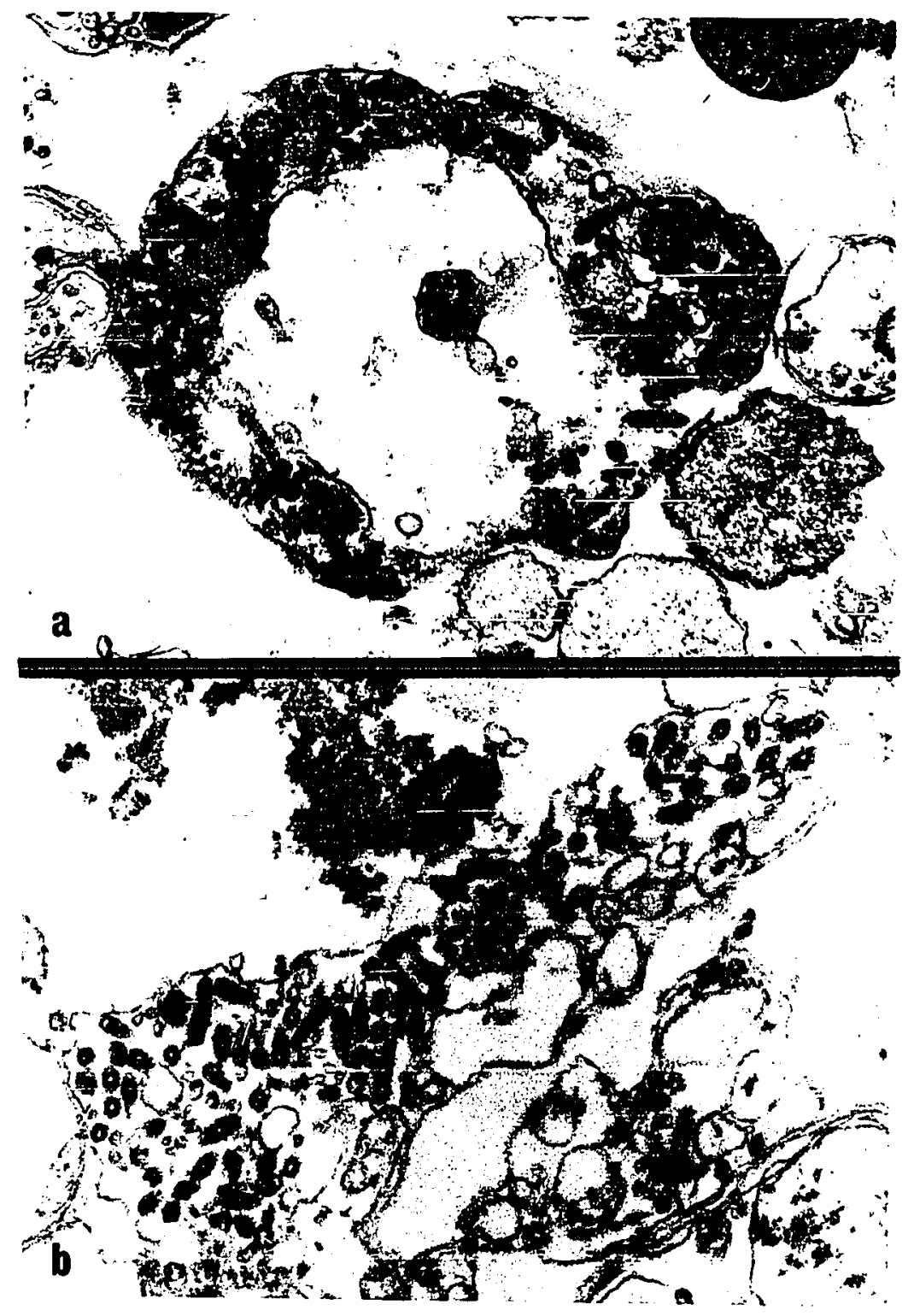


Fig. 29. Cocal virus in intracytoplasmic vacuoles of A. a albopictus cells. Magnification $100,000 \times$. 


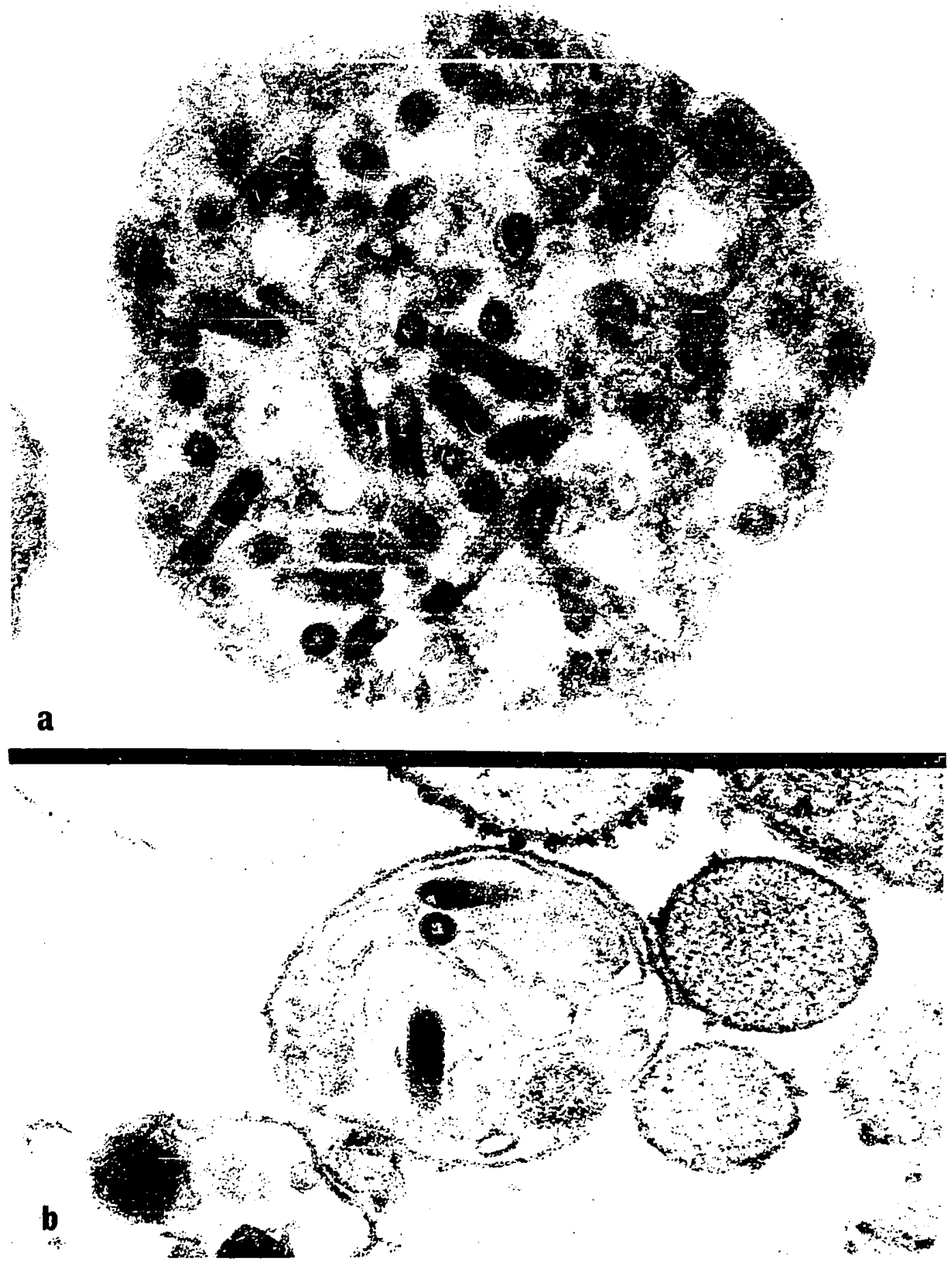


Fig. 30. Budding of Cocal virus in infected A. albopictus cells. Magnification 200,000 x.

a to c) Budding from intracytoplasmic membranes

d) Enveloped virus 


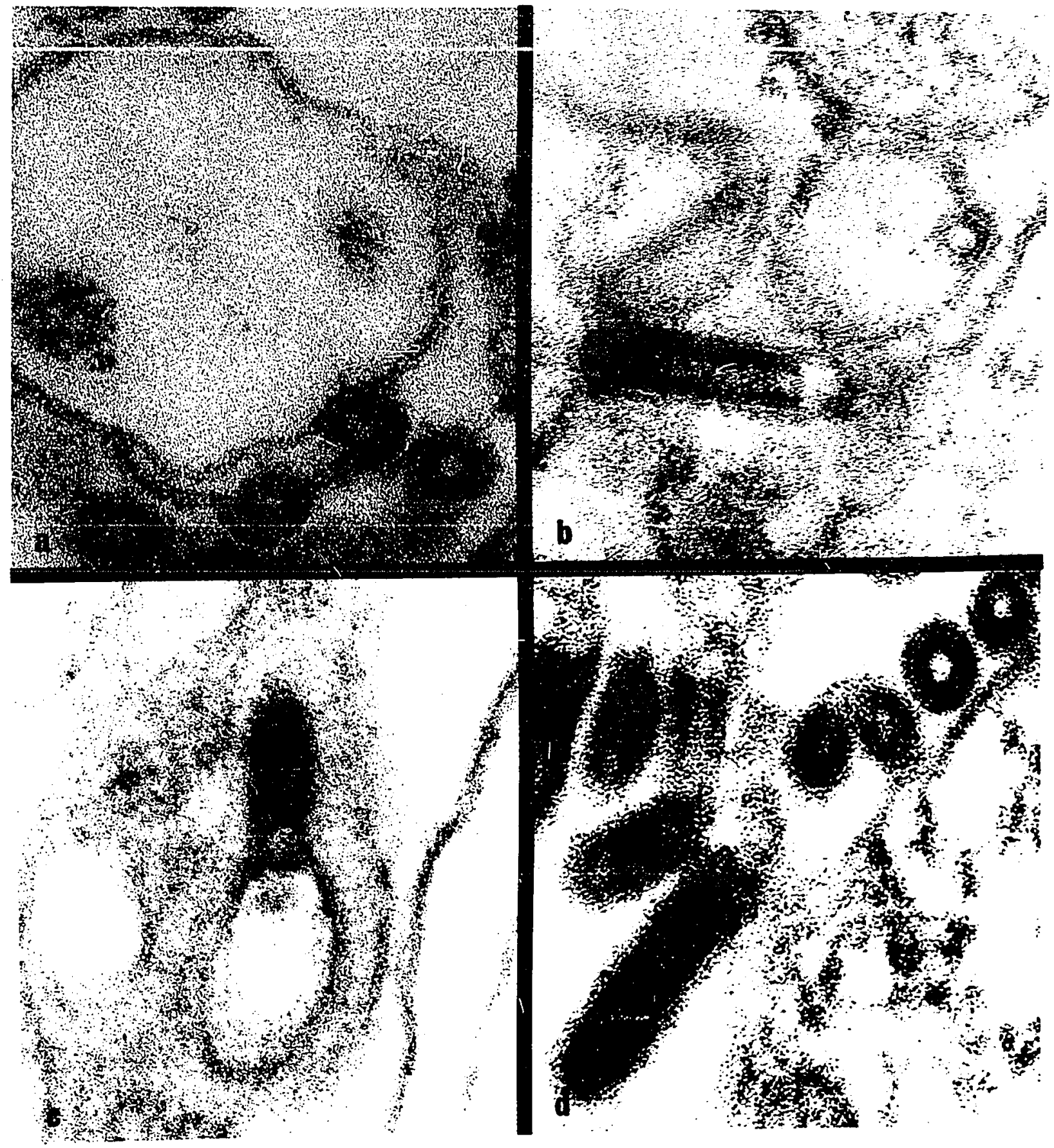


Fig. 31. Cocal virus from A. albopictus cells prepared by cell spread method.

a) Single particle with well defined fringe. Magnification 200,000 x.

b) Numerous bullet (B) and truncated (T) parricles. Magnification $120,000 x$.

c-d) Nucleocapsid strands from persistently infected cells. Magnification 120,000 x. 


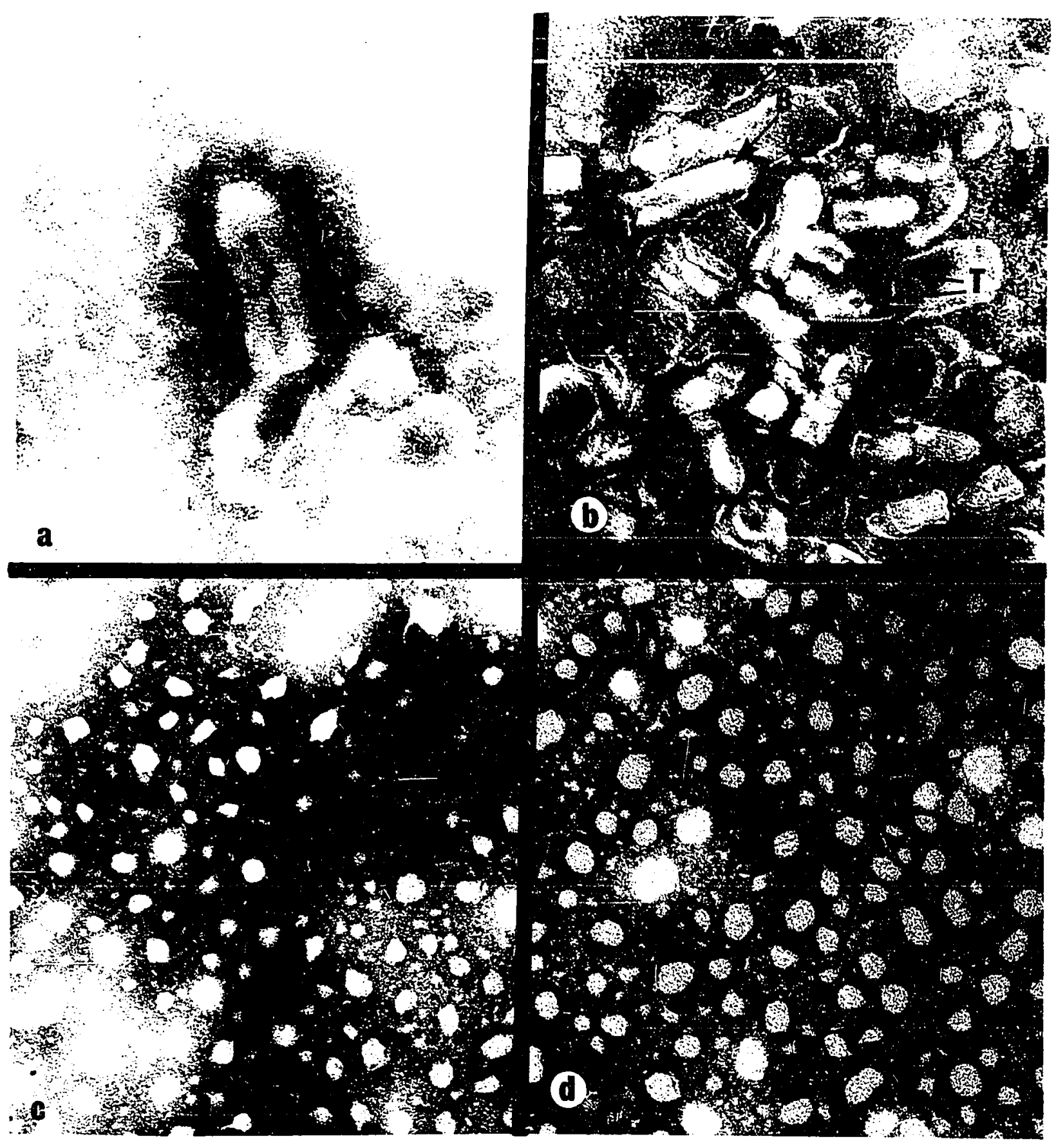



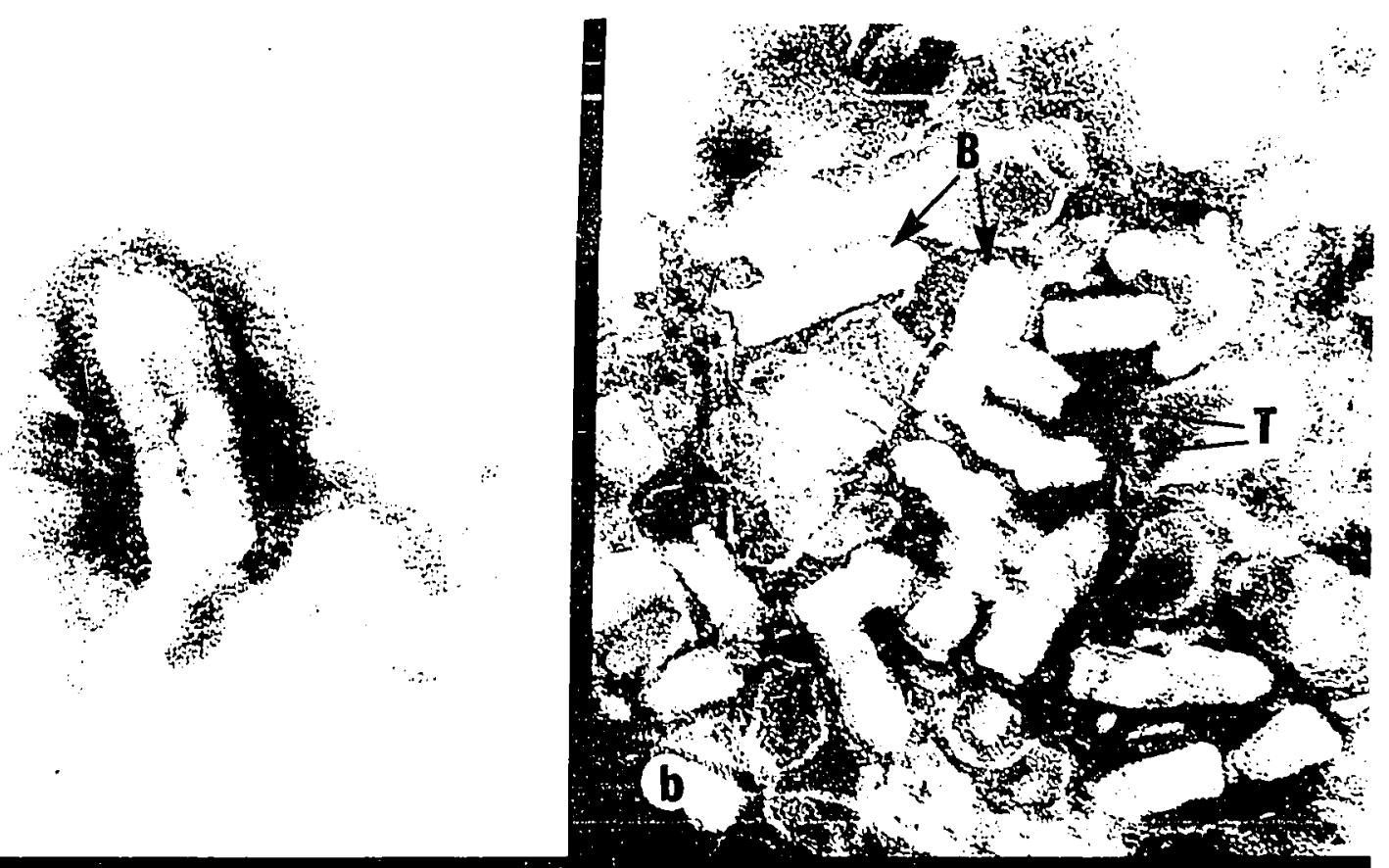

a

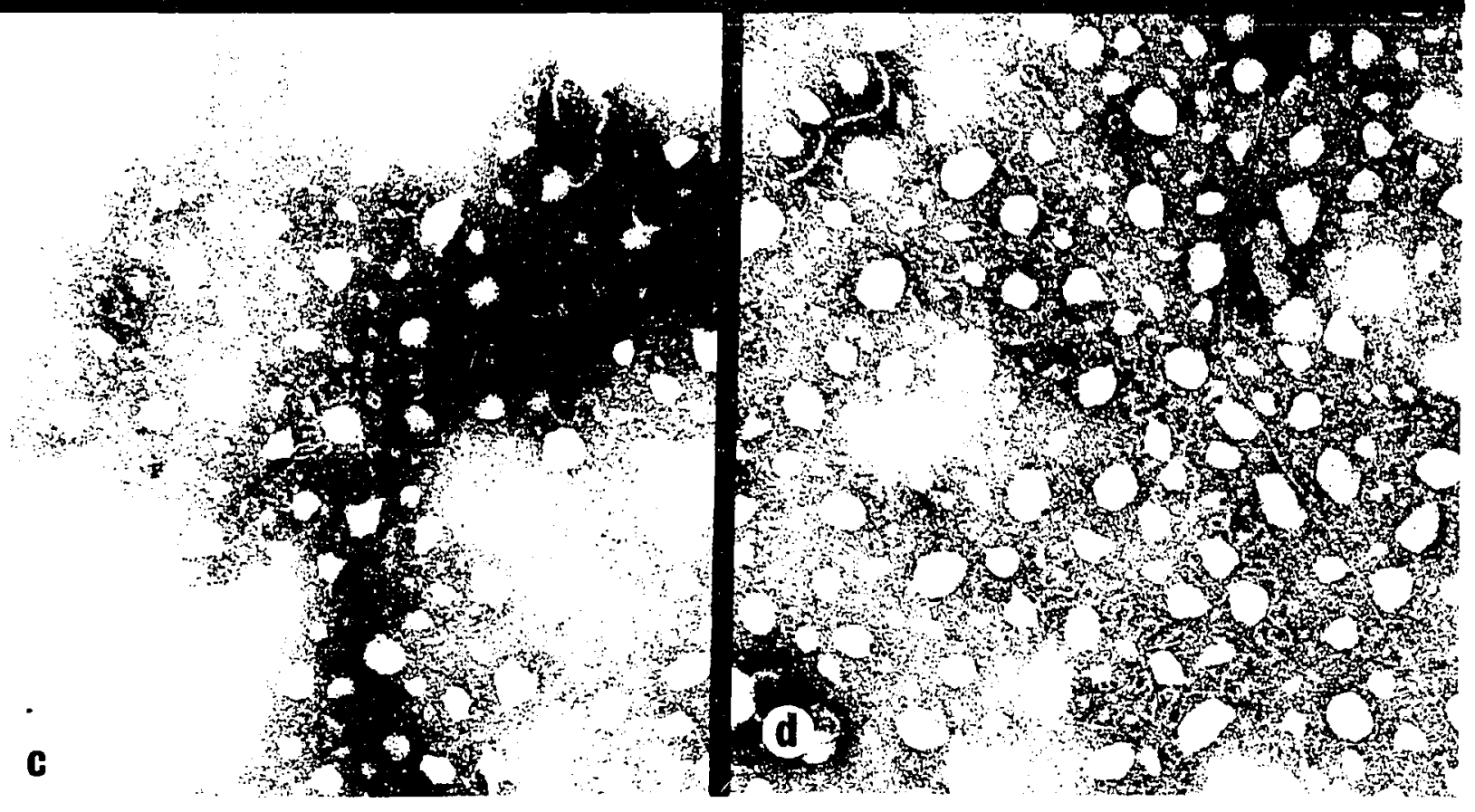


120.

One problem encountered in electron microscopic studies was an inability to distinguish the boundaries between mosquito cells, i.e. the plasma membranes between adjoining cells were often difficult to perceive. This problem was not due simply to the effect of higher temperature on mosquito cells since similar results were obtained at $30^{\circ} \mathrm{C}$. At the latter stage of the project, a new embedding medium was employed, i.e. Araldite versus Spurr, and appeared more suitable for maintaining intact structures in A. albopictus. However, this observation was made too late to influence studies reported in this thesis.

In all instances where intact cells were observed, Cocal was never detected budding from the plasma membrane, but virus particles were observed intracellularly (see Fig. 26), and enveloped particles were often seen in intracytoplasmic vesicles (see Fig. $27-28$ ). As demonstrated in Fig. 29, virus was also detected in vacuolar structures of different sizes either in large or small numbers.

The primary site of virus maturation occurred at intracytoplasmic rather than plasma membranes as exemplified by micrographs presented in Fig. 30. At no time during these studies were virus particles noted in nuclei of infected cells nor were intracytoplasmic crystals ever observed.

Examination of cell sections did not reveal whether long $(B)$ and short $(T)$ forms of Cocal were being synthesized by A. albopictus cells. Apparent production of both B and T particles was demonstrated (see Fig. $31 \mathrm{~b}$ ), but the possibility that the $T$ particles obtained under these conditions were just an artefact of the cell spread method must be considered. 
Finally, nucleocapsid strands were observed from a persistently infected cell preparation as shown in Fig. $31 \mathrm{c}+\mathrm{d}$. No complete virus particles were found in this preparation which contained less than $1 \%$ infected cells. 


\section{DISCUSSION}

The original observation that VSV Indiana and New Jersey serotypes can multiply in mosquito tissue culture was made by Buckley (1969). She inoculated varying dilutions of a virus pool into vertebrate (BHK-21, Vero) and mosquito (A. aegypti, A. albopictus) cell lines. The TCID 50 was detrrmined for BHK-21 and Vero cells. Since no cytopathic effect (CPE) occurred in mosquito cells, the $\mathrm{ID}_{50}$ was calculated by subinoculation of undiluted fluid inio vertebrate cells and observing for CPE to determine whether virus had replicated. By this means Buckley showed that $A$. aegypti was sensitive to a $5 \log$ greater dilution of virus than $\underline{A}$. albopictus. These results correlate with the findings with Cocal virus reported in Table 7 where all A. aegypti cultures were successfully infected with as little as 10 plaque forming units (p.f.u.) of virus (as measured in chick embryo) per bottle. Cultures of $A$. aegypti were also challenged with a calculated dose of 1 p.f.u. per bottle which, in practical terms, means that some bottles probably did not receive virus. Virus did in fact replicate in some of these latter dilutions and it is feasible that as small a dose as 1 p.f.u. was sufficient to initiate infection in A. aegypti. The same rationale can be applied to infection of mouse $L$ cells.

Although the experiment in which cultures of $\underline{A}$. albopictus proved refractory to infection with less than $10^{4}$ p.f.u. of virus (Table 7 ) was such that all 
unadsorbed virus was neutralized after adsorption for $1 \mathrm{hr}$, these results are in agreement with those of Buckley (1969). Furthermore, if these experiments were performed under in vivo conditions, it is unlikely that virus would be able to adsorb for long periods of time before elimination or inactivation.

Although it is dangerous to transpose results obtained from in vitro infection of cells originally derived from mosquito larvae to in vivo infection of specialized cells of the adult mosquito, there are interesting parallels to be drawn between infection under these differing conditions.

It is significant to note that the specificity of mosquito tissue is largely retained in vitro in that, with the exception of two tick borne arboviruses, only mosquito borne arboviruses will multiply in mosquito cell culture to produce infectious progeny.

Differences in ability to infect $\underline{A}$. albopictus and $\underline{A}$. aegypti cell lines at different input multiplicities is analogous to the threshold phenomenon observed during infection of adult mosquitoes (Chamberlain et al., 1954) i.e. a critical concentration of virus is required in the blood meal in order to establish gut infection in a significant proportion of vectors. A highly susceptible vector has a low threshold of infection while a less susceptible one has a higher threshold with these differences in susceptibility probably due to variations in the number of suitable receptor sites on the cells lining the gut (Chamberlain, 1968).

However, once the threshold "barrier" is overcome and infection is 
initiated, the virus develops with about equal ease in either low- or high-threshold species. By analogy, although $\underline{A}$. albopictus cells required a relatively high input multiplicity for infection, once infection was established virus titers attained were equivalent to those in the $\underline{A}$. aegypti cell line.

Pattyn and De Vleesschauwer (1970) and De Vleesschauwer and Pattyn (1970) reported that DEAE dextran when added to a blood-virus meal fed to $\underline{A}$. aegypti enhanced infection with one group B (West Nile) and three group A (Sindbis large and small plaque, Semliki Forest) arboviruses resulting in an increased number of infected mosquitoes. The authors speculated that DEAE dextran influenced the mosquito "gut barrier" by acting on the virus receptors to cause increased virus adsorption and subsequent penetration.

DEAE dextran was found to produce a simi lar effect in vitro causing increased adsorption of Cocal virus to both $\underline{A}$. aegypti and $\underline{A}$. albopictus cell lines. Also, when an input multiplicity of less than 0.01 was applied to A. albopictus cells, monolayers were infected only if virus was adsorbed in the presence of DEAE dextran. In vitro infection of mosquito cells was enhanced markedly in A. albopictus and to a slight extent in A. aegypti cell lines (see Fig. 8 - 10) when cells were incubated at the elevated temperature of $37^{\circ} \mathrm{C}$. Similarly, the temperature of incubation played a role in determining the rate of virus development in infected mosquitoes (Davis, 1932; Chamberlain and Sudia, 1955), i.e. the extrinsic incubation period in infected mosquitoes may range from only a few days at temperatures over $90^{\circ} \mathrm{F}$ to several weeks at temperatures of 60 to $70^{\circ} \mathrm{F}$. 
Dual infections were established between Cocal infected $\underline{A}$. albopictus cells and either Flanders, Mayaro, or Nepuyo virus with no apparent difference in virus titers between cells dually infected and cells infected with only one arbovirus. Similarly, dual infections have been reported in mosquitoes in vivo with virus replication generally occurring without interference between replicating arboviruses (Sabin, 1952; Chamberlain and Sudia, 1957; Altman, 1963; Lam and Marshall, 1968). Simultaneous infection can also occur in vertebrate animals or cell culture, but such interactions generally lead to depression of yield due to viral inferference (Fenner, 1968).

Finally, the gradual selection of small plaque Cocal virus from the normal plaque virus initially inoculated after passage of persistently infected mosquito cells is paralleled by an in vivo report by Pattyn and De Vleesschauwer (1968) who fed large and small plaque Middleburg virus to $\underline{A}$. aegypti and found that selection of small plaque virus tended to orcur.

Whereas virus titers in A. aegypti cells tended to remain fairly constant irrespective of the conditions of infection, great variability of virus tifers was observed in A. albopictus cells depending on the conditions of infection. The initial input multiplicity was important in determining the scope of infection in A. albopictus with an input multiplicity of 10 or 1 yielding optimal virus titers. The observation that cells infected at an input multiplicity of 0.1 yielded less p.f.u. of virus per cell is simi lar to the observation of Yang et al. (1969) who showed that VSV infection of Antheraea eucalypti cells varied according to the initial input multiplicity of virus. 
The influence of DEAE dextran in the early stages of interaction between Cocal virus and both mosquito cell lines (see Fig. 5 - 6) has been reported in other virus-cell systems including arboviruses (Pattyn and De Vleesschauwer, 1969) and rhabdoviruses (Kaplan et al., 1967; Chiu et al., 1970). The postulated mode of action of DEAE dextran is believed to involve either increased adsorption of virus to cells because of an electrostatic interaction (Allison and Valentine, 1960) or enhanced penetration as a result of reversible cell damage (Ryser, 1967). Miyamoto and Gilden (1971) presented electron microscopic photomicrographs showing DEAE dextran treated cells coated with an amorphous material at the cell surface which apparently enhanced firm attachment of virus to cells.

The fact that DEAE dextran combined with a low input multiplicity of virus increased infection of $\underline{A}$. albopictus cells indicates that virus adsorption to the cells was enhanced. However, increased efficiency of virus adsorption in the presence of DEAE dextran apparently occurred in only a fraction of the cell population as evidenced by the fact that DEAE dextran exerted its enhancing effect only under conditions of low input multiplicity of virus.

The influence of $37^{\circ} \mathrm{C}$ in enhancing replication of Cocal virus so that

all A. albopictus cells were infected is an original observation of some interest. Previously, Johnson (1969) and Peleg (1969) incubated primary and continuous A. aegypti cell cultures infected with arboviruses at $37^{\circ} \mathrm{C}$ and reported no greater virus titers than in cells similarly infected but incubated at lower temperatures. Libikova and Buckley (1971) reported a study concerning low grade infection of $\underline{A}$. albopictus 
cells with Kemerovo virus (KV) and they speculated that a factor in the inability of $\mathrm{KV}$ to multiply in some A. albopictus cells may relate to inadequate intracellular mechanisms in some mosquito cells. The studies reported in this thesis clearly demonstrate that although Cocal virus produced the typical low titered infection of an arbovirus in mosquito cells at $30^{\circ} \mathrm{C}$ involving only a small proportion of the cell population, all cells did in fact possess adequate synthetic machinery to replicate Cocal virus under appropriate conditions, as evidenced by $100 \%$ infection of cells at $37^{\circ} \mathrm{C}$.

Enhancement of infection at $37^{\circ} \mathrm{C}$ does not appear to be a temperature sensitive function of Cocal virus since high virus titers and CPE were observed in infected $\mathrm{L}$ cells incubated at $30^{\circ} \mathrm{C}$. Since $\underline{A}$. albopictus cells did not multiply when incubated at $37^{\circ} \mathrm{C}$, it is apparent that certain cellular functions are impaired at elevated temperatures. Therefore, it is possible that Cocal virus is normally unable to dominate host cell activities sufficiently to multiply in most $\underline{A}$. albopictus cells, but at $37^{\circ} \mathrm{C}$ virus specified enzymes can se lectively uti lize host cell synthetic machinery. Also, it is feasible that mosquito cells normally produce antiviral products that inhibit virus replication but synthesis of such substances is inhibited at $37^{\circ} \mathrm{C}$. The subsequent elimination of infective virus from most cells may simply reflect adaptation of pertinent host cell synthetic systems to $37^{\circ} \mathrm{C}$.

An alternative possibility relates to the sensitivity of $\underline{A}$. albopictus to autointerference as speculated previously (see Section IV.B.2.b.). It is feasible that a greater proportion of infective as opposed to autointerfering particles are produced 
at $37^{\circ} \mathrm{C}$ compared to $30^{\circ} \mathrm{C}$ in A. albopictus allowing for greater virus yields. Continued synthesis of autointerfering particles might, however, gradually reverse this effect leading to the decrease in virus titers that follows.

If infection of $\underline{A}_{.}$albopictus is regulated to some degree by autointerference, this might explain the observation that persistently infected cells when placed at $37^{\circ} \mathrm{C}$ experience absolutely no increase in tifers which might be expected according to the first hypothesis. A technique for the detection of non-infectious virus such as fluorescent antibody staining would have been a useful adjunct to these studies.

The small plaque variant of Cocal virus produced by persistently infected mosquito cells showed a decreased virulence for adult mice and was successfully used to protect mice against intracerebral challenge from normal plaque Cocal virus. Similarly, attenuation of A. albopictus produced Chikungunya virus for suckling mice has been reported by Banerjee and Singh (1969) and Peleg (1971) has reported the production of a small plaque variant of Semliki Forest virus from A. aegypti cells that showed a loss of virulence for adult but not for suckling mice and hamsters. Although small plaque Cocal virus demonstrated decreased virulence for adult mice and replicated to lower titer in L cells than normal plaque Cocal virus, it was observed that both normal and small plaque Cocal virus multiplied equally well in A. albopictus cell cultures. Thus, there was no apparent impairment in the ability of small plaque Cocal virus to multiply in mosquito cells.

Several publications deal with studies of small plaque VSV variants 
including those of Wagner et al. (1963), Shechmeister et al. (1967), and Youngner and Wertz (1968), but no conclusive evidence has been reported to explain small plaque production although Wagner et al. (1963) showed that the small plaque variant was more susceptible to the action of inferferon. Singh (1972) cited recent work by Buckley who studied Chikungunya virus attenuation in $\underline{A}$. albopictus and showed that loss of virulence depended specifically upon selection of small size plaques present in the original parent stock. A similar process may have occurred to select small plaque Cocal virus.

As well as possessing decreased virulence for adult mice, the small plaque Cocal variant produced in persistently infected mosquito cells demonstrated a change in ability to infect chick embryo and $\mathrm{BHK}-21$ cells relative to normal plaque Cocal virus. Whereas chick embryo was the most sensitive assay system for normal plaque Cocal virus, a more sensitive assay system for the small plaque variant was found to be the BHK-21 cell line. Johnson ef al. (1969) have proposed an intriguing biological alteration of VSV, i.e. they postulated that VSV is basically a plant virus that can infect animals only after replication in an arthropod (Phlebotomus) vector. The authors presented little evidence to support this hypothesis but, in light of the results presented in this thesis, it would be of interest to study the host range of VSV produced by infected mosquitoes or other arthropods compared to VSV produced by infected vertebrates. Such experiments might provide valuable clues for further elucidating the epidemiology of VSV.

Walker (1964) categorized the possible virus-animal carrier culture inter- 
actions as follows: (1) infections in cultures of genetically resistant cells; (2) infections in cultures of genetically susceptible cells protected by antiviral factors in the medium; (3) infections in cultures of genetically susceptible cells protected by interference and interferon; and (4) regulated infections of cells in culture.

$$
\text { Characteristics of } \underline{A} \text {. albopictus persistently infected cells presented in }
$$

Table 17 tend to categorize the carrier culture state as consisting of genetically resistant cells with a small proportion of susceptible cells. The fact that cultures were not cured by immune serum and that infected cells appeared capable of multiplying to maintain the carrier state differs slightly from Walker's definition but, as noted in Fig. 11, virus titers were much reduced after 10 passages under immune serum which could indicate inefficient multiplication of infected cells.

One important criterion to establish whether most $\underline{A}$. albopictus cells are genetically resistant to Cocal virus would be to infect cell clones. However, preliminary attempts to clone $\underline{A}$. albopictus cultures by the cell dilution (plating 10 cells per $\mathrm{ml}$ on Petri plates) and the capillary tube methods (Sanford et al., 1948) were unsuccessful, and this line of approach was discontinued.

If infected cells did not multiply as efficiently as uninfected cells, which is possible due to decreased titers of carrier cultures passaged under immune serum as well as apparent loss of virus from two A. albopictus "cured" cultures, it is difficult to explain the stability of virus titers in two A. albopictus cultures through 60 successive passages. Perhaps there occurred mutation of resistant to sensitive cells to help sustain infection or some virus was maintained in a partially replicated form not 
Summary of Cocal Carrier Culture Infection of A. albopictus

1. Infection limited to small proportion of cell population (usually less than $1 \%$ of the population).

2. Infection maintained through 10 successive passages under immune serum.

3. No antiviral factors demonstrated in medium.

4. a) Cultures resistant to superinfection with homologous virus.

b) Cultures can be superinfected with heterologous virus.

5. Inferferon production not detected. 
detrimental to replication of the infected cell. This latter possibility receives support from the ability of actinomycin $D$ to increase virus titers by $1 \log$ in persistently infected A. albopictus cultures as early as $6 \mathrm{hr}$ post-treatment (see Fig. 21). Numerous instances have been reported concerning establishment of persistently infected mosquito cells (see Literature Review), but no previous examples have been encountered concerning the development of resistant "cured" cultures. These cultures may play a role in helpirig to determine mechanisms of resistance to Cocal virus particularly in light of difficulties encountered in cell cloning.

Attempts to infect "cured" cultures with Cocal virus revealed that virus adsorbs to "cured" cultures as efficiently as to previously untreated cells (Fig. 17). Therefore, resistance to virus is a post adsorption step. No studies were undertaken to determine whether cellular resistance was due to lack of virus penetration or to a subsequent intracellular event. Interferon was not detected in assays performed and the fact that "cured" cultures were resistant to superinfection with homologous virus but could be superinfected with unre lated arboviruses also argues against interferon production having played a prominent role in loss of virus from these cultures.

Stevens (1970) reported that actinomycin D had little influence on titers of Sindbis virus in A. albopictus cells. While similar results were obtained with regard to Cocal infection of initially infected A. albopictus cultures, the rapid enhancement of titers in persistently infected cells is interesting and leads to the assumpition that virus is present in a partially replicated form in some persistently infected cells. Since actinomycin D inhibits DNA to RNA transcription, it is logical to assume that 
the cellular block to viral synthesis occurs either at the ribosomal level possibly upsetting a competitive balance between host cell and viral synthetic processes or at the level of protein synthesis, stopping synthesis of an antiviral protein. Taylor (1964) and Levine (1964) have shown previously that actinomycin can block interferon synthesis. Levine (1964) demonstrated that puromycin can also counteract interferon synthesis, but lack of effect of puromycin in experiments reported in this thesis should not be interpreted too strongly since no studies were undertaken to determine the effect of puromycin on mosquito cell metabolism.

Electron microscopic studies reported in this thesis confirm that Cocal virus matures primarily at the plasma membrane of $L$ cells and implicate intracytoplasmic vesicles as the primary site of virus maturation in $\underline{A}$. albopictus cells. It would be difficult, however, to relate the site of VSV maturation in infected cells with any cytopathic effect that ensues since VSV maturation in the non-cytopathic infection of Antheraea eucalypti moth cells occurs primarily at the plasma membrane of infected cells (Yang et al., 1969). Furthermore, Zee et al. (1970) reported that sites of VSV maturation differed in six vertebrate cell lines with the principal site of maturation at intracytoplasmic vacuolar membranes for a pig kidney cell line and at the plasma membrane for $L$ and Vero cells whereas both types of membranes served as sites in HeLa and BHK-21 cells.

In limited electron microscopic observations of persistently infected A. albopictus cells by the cell spread method, no complete virus particles were noted presumably due to low virus titers. However, on one occasion, a number of nucleo- 
134.

capsid strands were observed (see Fig. 31). Although this observation was not reconfirmed in two subsequent examinations, nucleocapsid strands were never observed in high titered Cocal-mosquito cell preparations and, in light of the actinomycin D experiments, it is interesting to speculate that nucleocapsid strands might exist uncoated in a number of persistently infected cells. Studies along these lines appear warranted. 


\section{SUMMARY}

1. Cocal strain of VSV was propagated in $\underline{A}$. albopictus and $\underline{A}$. aegypti cell lines as well as in L cells at $30^{\circ} \mathrm{C}$. Infection of mosquito cells resulted in a low titered infection generally involving only a small proportion of the cell population with no resulting CPE. Whereas $\underline{A}$. aegypti and $L$ cells were readily infected with a low input multiplicity of virus, A. albopictus cells were not infected with an input multiplicity of less than 0.01 under the experimental conditions employed.

2. Virus titers of $\underline{A}$. albopictus cells were influenced by the input multiplicity used and were increased by adsorption in the presence of DEAE dextran or by incubation of cells at $37^{\circ} \mathrm{C}$. Under these latter conditions, $100 \%$ infection of mosquito cells was obtained.

3. Persistent infection of both mosquito cell lines was maintained for up to 60 passages. However, virus was lost from two of four A. albopictus cell lines by passages 20 and 30 , respectively. Persistently infected cells multiplied at the same rate as uninfected confrols.

4. Properties of virus produced in persistently infected cells were found to be altered with regard to relative abilities to infect different cell lines, size of plaques produced, and virulence for adult mice. 
5. Persistently infected and "cured" cultures of A. albopictus were resistant to superinfection with homologous virus but were superinfected with unrelated arboviruses. Resistance of "cured" cultures to superinfection with homologous virus was not due to inability of virus to adsorb to cells.

6. No antiviral factors were demonstrated in the mosquito medium and no interferon production was detected by A. albopictus in the crude assays performed.

7. Virus infection was maintained through 10 successive passages under immune serum indicating an ability of infected cells to divide.

8. Cocal virus was found to multiply in A. albopictus cells in the presence of actinomycin D. Whereas actinomycin D had little influence on virus titers in initially infected cells, titers of persistently infected cells were increased by 1 - 2 logs as early as $6 \mathrm{hr}$ post-treatment. Puromyc in treatment had no enhancing effect on virus titers.

9. Electron microscopic studies of infected $L$ cells revealed that maturation of Cocal virus occurred primarily at the plasma membrane whereas a limited election microscopic study of infected A. albopictus cells indicated that the main site of virus maturation was at intracellu lar vesicles. 


\section{CONTRIBUTIONS TO KNOWLEDGE}

1. Ability of Cocal virus to initiate low titered infection of $\underline{A}$. aegypti and A. albopictus cultures was demonstrated and the host range of A. albopictus was extended to include Flanders, Mayaro, and Nepuyo viruses.

2. Initial input multiplicity employed was demonstrated to influence the extent of Cocal infection of $\underline{A}$. albopictus but not $\underline{A}$. aegypti cells.

3. Efficiency of virus adsorption to both mosquito cell lines was shown to be enhanced by the use of DEAE dextran.

4. Incubation of infected A. albopictus cells at $37^{\circ} \mathrm{C}$ resulted in $100 \%$ infection of cells and high virus titers. This demonstrated that under appropriate conditions all mosquito cells possess adequate intracellular synthetic mechanisms for the replication of Cocal virus.

5. Persistent infection was established in both mosquito cell lines. However, two of four infected A. albopictus cultures eliminated virus and were resistant to superinfection with homologous virus but could be superinfected with unrelated arboviruses. No such examples of "cured" mosquito cultures have been reported previously. 
6. Virus from persistently infected cells produced smaller plaques and was less virulent for adult mice. There are only two previous reports of virus attenuation in mosquito cells. In addition, small plaque virus differed from normal plaque Cocal in relative abilities to infect $\mathrm{BHK}-21$ and chick embryo cells.

7. Cocal virus was maintained in A. albopictus cells through 10 successive passages under immune serum.

8. Studies summarized in Table 17 indicated that most A. albopictus cells were genetically resistant to Cocal virus at $30^{\circ} \mathrm{C}$ with only a small proportion of susceptible cells. Infection of A. albopictus "cured" cultures revealed that resistance of cells to Cocal virus was a post adsorption step.

9. Actinomycin D treatment rapidly increased titers in persistently infected A. albopictus cells indicating that virus is suppressed in partially replicated form in some cells.

10. Limited electron microscopic studies revealed that Cocal virus replication in A. albopictus cells is not notably different from its replication in numerous vertebrate cell lines. 


\section{APPENDIX}

A. MEDIA

1. BHK-21 Growth Medium

BHK-21 medium (Gibco) $\quad 80 \%$

Tryptose phosphate broth $\quad 10 \%$

Calf serum $\quad 10 \%$

Gentamicin $\quad 15 \mu \mathrm{g} / \mathrm{ml}$

Mycostatin $\quad 10$ units $/ \mathrm{ml}$

Tryptose phosphate broth (Difco) powder containing:

$\begin{array}{lr}\text { Bacto tryptose } & 20 \mathrm{~g} / 1 \\ \text { Bacto dextrose } & 2 \mathrm{~g} / 1 \\ \text { Sodium chloride } & 5 \mathrm{~g} / 1 \\ \text { Disodium phosphate } & 2.5 \mathrm{~g} / 1\end{array}$

Dissolve $29.5 \mathrm{~g}$ in $1000 \mathrm{ml}$ distilled water. Sterilize by autoclave for $15 \mathrm{~min}$ at $15 \mathrm{lb}\left(121^{\circ} \mathrm{C}\right)$. 
2. Chick Embryo and L Cells Growth Medium

$\begin{array}{ll}\begin{array}{l}\text { Minimum essential medium } \\ \text { (Eagle's) with Earle' s salts } \\ \text { (Gibco) }\end{array} & 9.8 \mathrm{~g} \\ \text { Sodium bicarbonate } & 2.2 \mathrm{~g} \\ \text { Lactalbumin hydrolysate } & 5.0 \mathrm{~g} \\ \text { Yeast extract } & 1.0 \mathrm{~g}\end{array}$

Dissolve in $1 \mathrm{I}$ of distilled water, filter through a millipore membrane $0.22 \mu$ pore size and add:

$\begin{array}{ll}\text { Calf serum } & 10 \% \\ \text { Gentamicin } & 15 \mu \mathrm{g} / \mathrm{ml} \\ \text { Mycostatin } & 10 \text { units } / \mathrm{ml}\end{array}$

3. Maintenance Medium No. 3 (Gibco)

Components:

Minimum essential medium (Eagle's)

$49 \%$

Medium 199

$49 \%$

Gamma globulin-free calf serum

Gentamicin

$15 \mu \mathrm{g} / \mathrm{ml}$

Mycostatin

10 units $/ \mathrm{ml}$ 
iii.

4. Plaque Overlay Medium

a) Nutrient Medium (2x)

Minimum essential medium
(Eagle's) with Earle's salts
(Gibco)
$\begin{array}{ll}\text { Sodium bicarbonate } & 19.6 \mathrm{~g}\end{array}$

Dissolve in 11 distilled water, filter through a millipore membrane filter, $0.22 \mu$ pore size. Add:

$\begin{array}{ll}\begin{array}{l}\text { Gamma globulin-free calf } \\ \text { serum }\end{array} & 5 \% \\ \text { Gentamicin } & 30 \mu \mathrm{g} / \mathrm{ml} \\ \text { Mycostatin } & 20 \text { units } / \mathrm{ml}\end{array}$

b) Agarose Solution

Agarose ( $L$ ' industrie Biologique Française) $\quad 14 \mathrm{~g}$

Dissolve in $1000 \mathrm{ml}$ distilled water. Autoclave for $15 \mathrm{~min}$ at $15 \mathrm{lb}$ $\left(121^{\circ} \mathrm{C}\right)$. Cool to $42^{\circ} \mathrm{C}$. Mix equal volumes of (a) and (b) and hold at $42^{\circ} \mathrm{C}$ until used. 
5. Mosquito Cell Culture Media

a) Mitsuhashi-Maramorosch (MM) Growth Medium (MM 80-20)

$\begin{array}{ll}\text { Glucose } & 5.00 \mathrm{~g} \\ \begin{array}{ll}\text { Lacta lbumin hydrolysate } & \\ \text { (Difco) } & 8.15 \mathrm{~g} \\ \text { Yeastolate (Difco) } & 6.25 \mathrm{~g}\end{array}\end{array}$

Dissolve in $800 \mathrm{ml}$ distilled water. Add $100 \mathrm{ml}$ of salts $A$ and $100 \mathrm{ml}$ of salts $B$.

$\underline{\text { Salts A }}$

$$
\begin{array}{lr}
\mathrm{NaH}_{2} \mathrm{PO}_{4} \cdot 2 \mathrm{H}_{2} \mathrm{O} & 2.83 \mathrm{~g} / \mathrm{I} \\
\mathrm{MgCl}_{2} \cdot 6 \mathrm{H}_{2} \mathrm{O} & 1.25 \mathrm{~g} / \mathrm{I} \\
\mathrm{KCl} & 2.50 \mathrm{~g} / \mathrm{I} \\
\mathrm{CaCl}_{2} \cdot 2 \mathrm{H}_{2} \mathrm{O} & 2.50 \mathrm{~g} / \mathrm{I} \\
\mathrm{NaCl} & 87.50 \mathrm{~g} / \mathrm{I}
\end{array}
$$

Salts B

$$
\mathrm{NaHCO}_{3} \quad 1.50 \mathrm{~g} / \mathrm{I}
$$

Filter through a millipore membrane $0.22 \mu$ pore size. Add: 
Fetal calf serum

(heat inactivated)

Gentamicin

Mycostatin
$20 \%$

$15 \mu \mathrm{g} / \mathrm{ml}$

10 units $/ \mathrm{ml}$

b) MM Maintenance Medium (MM 97-3)

Formula as in $5 . a$. but use only $3 \%$ fetal calf serum.

c) Mosquito Storage Medium

$\begin{array}{ll}\text { Basic MM medium } & 50 \mathrm{ml} \\ \begin{array}{l}\text { Fetal calf serum } \\ \text { (heat inactivated) }\end{array} & 40 \mathrm{ml} \\ \text { Glycerol } & 10 \mathrm{ml} \\ \text { Gentamicin } & 15 \mu \mathrm{g} / \mathrm{ml} \\ \text { Mycostatin } & 10 \text { units } / \mathrm{ml}\end{array}$

B. DILUENT

Phosphate Buffered Saline (PBS)

a) Dulbecco A tablets (Oxoid Ltd.)

Sodium chloride

$8.00 \mathrm{~g} / 1$

Potassium chloride

$0.20 \mathrm{~g} / \mathrm{l}$

(To be continued) 
a) Dulbecco A tablets (Oxoid Ltd.) (Continued)

$$
\begin{array}{ll}
\text { Disodium hydrogen phosphate } & 1.15 \mathrm{~g} / \mathrm{l} \\
\begin{array}{l}
\text { Potassium dihydrogen } \\
\text { phosphate }
\end{array} & 0.20 \mathrm{~g} / \mathrm{l}
\end{array}
$$

Dissolve one tablet in $100 \mathrm{ml}$ distilled water. Autoclave at $10 \mathrm{lb}\left(115^{\circ} \mathrm{C}\right)$ for $10 \mathrm{~min} . \mathrm{pH} 7.3$.

b) Dulbecco B ampoules (Oxoid Ltd.)

$$
\begin{array}{ll}
\text { Calcium chloride } & 0.1 \mathrm{~g} / \mathrm{l} \\
\text { Magnesium chloride } & 0.1 \mathrm{~g} / \mathrm{l} \\
\text { Distilled water } & \text { to } 5 \mathrm{ml}
\end{array}
$$

Add one $5 \mathrm{ml}$ ampoule to each liter of Dulbecco A solution to make complete Dulbecco Phosphate Buffered Saline pH 7.4.

\section{REAGENTS AND STAINS FOR TISSUE CULTURE}

1. Trypsin Solution

$\begin{array}{lr}\begin{array}{l}\text { Trypsin powder (Fisher } \\ \text { Sc ientific) }\end{array} & 2.5 \mathrm{~g} \\ \text { Phosphate buffered saline } & 1 \mathrm{l}\end{array}$

Dissolve and filter through a millipore filter $0.22 \mu$ pore size. Store at $-20^{\circ} \mathrm{C}$. 
vii.

2. Pronase Solution

Pronase, B grade

(Calbiochem.) $\quad 1.0 \mathrm{~g}$

Distilled water $\quad 100 \mathrm{ml}$

Dissolve and filter through a millipore filter $0.22 \mu$ pore size. Store at $-20^{\circ} \mathrm{C}$. Dilute to $0.1 \%$ in PQS when ready to use.

3. DEAE Dextran

$\begin{array}{ll}\text { DEAE dextran (Pharmacia) } & 1.0 \mathrm{~g} \\ \text { Distilled water } & 100 \mathrm{ml}\end{array}$

Autoclave at $15 \mathrm{lb}\left(121^{\circ} \mathrm{C}\right)$ for $15 \mathrm{~min}$. Store stock solution at $4^{\circ} \mathrm{C}$.

4. Actinomycin D

$\begin{array}{lr}\text { Actinomycin D (Sigma) } & 5 \mathrm{mg} \\ \text { Distilled water } & 5 \mathrm{ml}\end{array}$

Dissolve and filter through a millipore filter $0.22 \mu$ pore size. Store stock solution in dark at $-20^{\circ} \mathrm{C}$. 
viii.

5. Puromycin

Puromycin dihydrochloride (Nutritional Biochem.)

Distilled water
$50 \mathrm{mg}$

$10 \mathrm{ml}$

Dissolve and filter through a millipore filter $0.22 \mu$ pore size. Store stock solution at $-20^{\circ} \mathrm{C}$.

6. Neutral Red

Neutral Red solution $1 / 300$ (Gibco). Dissolve in saline to make a $1 / 10,000$ solution.

7. Trypan Blue

Trypan blue stain 0.4\% in Hank's BSS (Gibco). Dilute 1:2 with saline and mix with an equal volume of cell suspension for cell counts.

8. Freund's Complete Adjuvant (Difco)
Arlacel A
$1.5 \mathrm{ml}$
Bayol F
$8.5 \mathrm{ml}$
Mycobacterium butyricum
(killed and dried) 
ix.

\section{REAGENTS FOR ELECTRON MICROSCOPY}

1. Phosphotungstic Acid - $2 \%$

$\begin{array}{ll}\text { Phosphotungstic acid } & 1.0 \mathrm{~g} \\ \text { Distilled water } & 50 \mathrm{ml}\end{array}$

Adjust $\mathrm{pH}$ to 7.2 with $\mathrm{N} / \mathrm{I} \mathrm{NaOH}$ and store at $4^{\circ} \mathrm{C}$.

2. Sorenson's Phosphate Buffer $-0.1 \mathrm{M}$

Component A

$$
0.2 \mathrm{M} \mathrm{NaH}_{2} \mathrm{PO}_{4} \cdot \mathrm{H}_{2} \mathrm{O} \quad 27.6 \mathrm{~g} / \mathrm{I}
$$

Component B

$$
0.2 \mathrm{M} \mathrm{Na}_{2} \mathrm{HPO}_{4} \quad 28.4 \mathrm{~g} / \mathrm{I}
$$

Mix $19.0 \mathrm{ml}$ component A with $81.0 \mathrm{ml}$ component B. Dilute in distilled water to $200 \mathrm{ml}$.

3. Glutaraldehyde Fixative

70\% glutaraldehyde (Ladd) $\quad 2$ r.l

0.1 M Sorenson's phosphate buffer

$68 \mathrm{ml}$

Mix to get final concentration of $2 \%$ glutaraldehyde, $\mathrm{pH} 7.4$. 
4. Osmium Tetroxide $(2 \%)+$ Sucrose

Veronal acetate buffer $(0.28 \mathrm{M})$

$10 \mathrm{ml}$

$0.1 \mathrm{~N} \mathrm{HCl}$

approx. $10 \mathrm{ml}$ (to $\mathrm{pH} 7.5$ )

Dilute with distilled water to total volume of $50 \mathrm{ml}$. Add $2.25 \mathrm{~g}$ of sucrose to the solution.

5. Spurr Embedding Medium (Polysciences Inc.)

Prepare soft embedding medium as oufiined in Polysciences Data Sheet

No. 127.
Vinylcyclohexene dioxide $\quad 10.0 \mathrm{~g}$
Diglycidyl ether of
polypropylene glycol $736 \quad 7.0 \mathrm{~g}$
Nonenyl succinic anhydride $26.0 \mathrm{~g}$
Dimethyl amino ethanol $\quad 0.4 \mathrm{~g}$ 


\section{BIBLIOGRAPHY}

ALLISON, A.C. and Valentine, R.C. 1960. Virus particle adsorption. III Adsorption of viruses by cell monolayers and effects of some variables on adsorption. Biochim. Biophys. Acta, $40: 400-10$.

ALTMAN, R.M. 1963. The behaviour of Murray Valley encephalitis virus in Culex tritaeniorhynchus Giles and Culex pipiens quinquefasciatus Say. Am. J. Trop. Med. Hyg., $12: 425-34$.

ANDERSON, N. and Doane, F.W. 1972. Microscopic detection of adventitious viruses in cell cultures. Canad. J. Microbiol., 18 : 299 - 304.

BANERJEE, K. and Singh, K.R.P. 1968. Establishment of carrier cultures of Aedes albopictus cell line infected with arboviruses. Ind. J. Med. Res., 56: $812-14$.

BANERJEE, K. and Singh, K.R.P. 1969. Loss of mouse virulence in Chikungunya virus from the carrier culture of Aedes albopictus cell line. Ind. J. Med. Res., 57 : $1003-5$.

BERGOLD, G.H. and Munz, K. 1967. Ultrastructure of Cocal, Indiana, and New Jersey serotypes vesicular stomatitis virus. J. Ultrastructure Res., 17 : $233-44$.

BERGOLD, G.H. and Munz, K. 1970. Characterization of Piry virus. Arch. ges. Virusforsch., $31: 152-67$.

BERGOLD, G.H., Suarez, O.M. and Munz, K. 1968. Multiplication in and transmission by Aedes aegypiti of vesicular stomatitis virus. J. Invert. Path., $11: 406-28$.

BHAT, U.K.M. and Singh, K.R.P. 1969. Structure and development of vesicles in larval tissue culture of Aedes aegypti (L). J. Med. Entom. 6 : 71 - 74.

BROOKS, M.A. and Kurtti, T.J. 1971. Insect cell and tissue culture. Ann. Rev. Entom., 16: $27-52$. 
BROWN, L.N. and Packer, R.A. 1964. Some factors affecting plaque size of western equine encephalomyelitis virus. Am. J. Vet. Res. $25: 487$ - 93.

BUCKLEY, S.M. 1969. Susceptibility of the Aedes albopictus and Aedes aegypti cell lines to infection with arboviruses. Proc. Soc. Exp. Biol. Med., $131: 625-30$.

BUCKLEY, S. M. 197la. Infection of an Aedes albopictus cell line with an arbovirus isolated from Anopheline mosquitoes. Trans. R. Soc. Trop. Med. Hyg. , 65 : $535-36$.

BUCKLEY, S.M. 1971 b. Multiplication of Chikungunya and $O^{\prime}$ nyong-nyong viruses in Singh's Aedes cell lines. Curr. Top. Microbiol. Imm, $55: 133-37$.

CARTWRIGHT, B. and Brown, F. 1972. Serological relationships between different strains of vesicular stomatitis virus. J. Gen. Virol., 16 : 391 - 98.

CASALS, J. 1961. Procedures for identification of arthropod-borne viruses. Bull. Wld. Hlth. Org., 24 : $723-34$.

CHAMBERLAIN, R.W. 1968. Arboviruses, the arthropod-borne animal viruses. Curr. Top. Microbiol. Imm., 42 : 38 - 58 .

CHAMBERLAIN, R.W., Nelson, D.B. and Sudia, W.D. 1954. Studies on the North American arthropod-borne encephalitides. VI. Quantitative determinations of virus-vector relationships. Am. J. Hyg., 60 : $278-85$.

CHAMBERLAIN, R.W. and Sudia, W.D. 1955. The effects of temperature upon the extrinsic incubation of eastern equine encephalitis in mosquitoes. Am. J. Hyg. 62 : $295-305$.

CHAMBERLAIN, R.W. and Sudia, W.D. 1957. Dual infections of eastern and western equine encephalitis virus in Culex tarsalis. J. Infect. Dis., $101: 233-36$.

CHAO, J. and Ball, G.H. 1971. A cell line isolated from hemocytes of Samia cynthia pupae. Curr. Top. Microbiol. Imm., 55 : 28 - 32 .

CHIU, R.J. and Black, L. M. 1967. Monolayer cultures of insect cell lines and their inoculation with a plant virus. Nature, $215: 1076-78$. 
xiii.

CHIU, R.-J., Liu, H.-Y., MacLeod, R, and Black, L. M. 1970. Potato yellow dwarf virus in leafhopper cell culfure. Virology, $40: 387-96$.

CONVERSE, J.L. and Nagle, S.C., Jr. 1967. Multiplication of yellow fever virus in insect tissue cell cultures. J. Virol., $1: 1096-97$.

COOPER, P.D. 1967. The plaque assay of animal viruses. In Methods in Virology III, pp. 234 - 311. Ed. K. Maramorosch and K. Koprowski. Acad. Press, N.Y.

CORY, J. and Yunker, C.E. 1972. Arbovirus plaques in mosquito cell monolayers. Acta Virol., $16: 90$

CROMACK, A.S. 1968. An electron microscope study of virus-like particles in chick embryo and L cell cultures. J. Gen. Virol., 2 : 195 - 98.

DALES, S. and Howatson, A.F. 1961. Virus-like particles in association with L strain cells. Cancer Res. 21 : $193-97$.

DAVIS, N.C. 1932. The effect of various temperatures in modifying the extrinsic incubation period of yellow fever virus in Aedes aegypti. Am. J. Hyg., $16: 163-76$.

DENNETT, D.P., Kelly, M.W., De Smet, M.A. and Dalgarno, L. 1970. The growth of Kunjin, a group $B$ arbovirus, in cultured vertebrate and mosquito cells. Proc. Aust. Biochem. Soc., $3: 46$.

DE VLEESSCHAUWER, L. and Pattyn, S.R. 1970. The enhancing effect of diethylamino-ethyl (DEAE)-dextran on the infectivity of some arboviruses for Aedes aegypti. Antonie van Leeuwenhoek, $36: 188$.

DITCHFIELD, J. and Almeida, J.D. 1964. The fine structure of Cocal virus. Virology, $24: 232-35$.

DONALDSON, A.I. 1970. Bats as possible hosts for vesicular stomatitis virus. Am. J. Epid., 92 : $132-36$.

DULBECCO, R. 1952. Production of plaques in monolayer tissue cultures by sirigle particles of animal viruses. Proc. Nat. Acad. Sci., 38 : $747-52$.

DULBECCO, R. and Vogt, M. 1954. One-step growth curve of western equine encephalomyelitis virus on chicken embryo cells grown in vitro and analysis of virus yields from single cells. J. Exp. Med., 99 : $183-99$. 
ECHALIER, G. and Ohanessian, A. 1968. Cultures in vitro de cellules de Drosophile. Obtention d'une souche à multiplication continue, pp. 174-81, Milano: 1st Lombardo Sci. Lettri Baselli Foundation.

ELLIS, E.M. and Kendall, H.E. 1964. The public health and economic effects of vesicular stomatitis in a herd of dairy cattle. J.A.V.M.A., 144 : $377-80$.

FEDERER, K.E., Burrows, R. and Brooksby, J.B. 1967. Vesicular stomatit is virus the relctionship between some strains of the Indiana serotype. Res. Vet. Sci., 8 : $103-17$.

FENNER, J. 1968. The biology of animal viruses. Acad. Press, New York. N.Y.

FERRIS, D.H., Hanson, R.P., Dicke, R.J. and Roberts, R.H. 1955. Experimental transmission of vesicular stomatitis virus by Diptera. J. Infect. Dis., 96 : $184-92$.

FILSHIE, B.K. and Rehacek, J. 1968. Studies of the morphology of Murray Valley encephalitis and Japanese encepha! itis viruses growing in cultured mosquito cells. Virology, $34: 435-43$.

FUJITA, N., Yasui, Y., Kitamura, S. and Hotta, S. 1968. Cultivation of Japanese encephalitis (J.E.) virus in primary Culex mosquito tissue cultures. Kobe J. Med. Sci., 14: $241-49$.

GLASER, R.W. 1917. The growth of insect blood cells in vitro. Psyche, $24: 1-7$.

GOLDSCHMIDT, R. 1915. Some experiments on spermatogenesis in vitro. Proc. Nat. Acad. Sci. U.S., 1 : $220-22$.

GRACE, T.D.C. 1958a. The prolonged growth and survival of ovarian tissue of the promethea moth (Callnsamia promethea) in vitro. J. Gen. Physiol., $41: 1027-34$.

GRACE, T.D.C. 1958b. Tissue culture for arthropods. Ann. N.Y. Acad. Sci., $77: 275-82$.

GRACE, T.D.C. 1958c. Effects of various substances on growth of silkworm tissues grown in vitro. Aust. J. Biol. Sci., $11: 407-17$.

GRACE, T.D.C. 1962. Establishment of four strains of cells from insect tissues grown in vitro. Nature, $195: 788-89$. 
GRACE, T.D.C. 1966. Establishment of a line of mosquito (Aedes aegypti L.) cells grown in vitro. Nature, $211: 366-67$.

GRACE, T.D.C. 1967a. Establishment of a line of cells from the silkworm Bombyx mori. Nature, $216: 613$.

GRACE, T.D.C. 1967b. Insect cell culture and virus research. In Vitro, 3 : $104-17$.

GRACE, T.D.C. 1968. The development of clones from lines of Antheraea eucalypti cells grown in vitro. Exp. Cell Res., $52: 451-58$.

GRACE, T.D.C. 1969. Insect tissue culture and its use in virus research. Adv. Virus Res., 14 : $201-20$.

HAINES, T.W. 1959. Tissue culture of Aedes aegypti cells and its application in studies on the behavior of eastern equine encephalomyelitis virus. Diss. Abst. , 20 : 31 .

HALONEN, P.E., Murphy, F.A., Fields, B.N. and Reese, D.R. 1968. Haemagglutinin of rabies and some other bullet-shaped viruses. Proc. Soc. Exp. Biol. Med., 127 : 1037 - 42.

HANN, W.D. and Clarke, R.B. 1971. Attempts to grow Tacaribe and Junin viruses in Grace's continuous line of moth cells. Curr. Top. Microbiol. Imm., 55 : $149-50$.

HANNOUN, C. and Echalier, G. 1971. Arbovirus multiplication in an established diploid cell line of Drosophila melanogaster. Curr. Top. Microbiol. Imm. , 55 : $227-30$.

HANSON, R.P. 1952. The natural history of vesicular stomatitis. Bact. Rev., $16: 179-204$.

HANSON, R.P. 1968. Discussion of the natural history of vesicular stomatitis. Am. J. Epid., 87 : $264-66$.

HANSON, R.P. and Brandly, C.A. 1957. Epizootiology of vesicular stomatitis. Am. J. Pub. H!th.; 47 : $205-9$.

HARLBUT, H.S. and Thomas, J.I. 1969. Further studies on the arthropod host range of arboviruses. J. Med. Entom., 6 : $423-27$. 
HINK, W.F. 1970. Established insect cell line from the cabbage looper, Trichoplusia ni. Nature, $226: 466-67$.

HINK, W.F. and Ellis, B.J. 1971. Establishment and characterization of two new cell lines (CP-1268 and CP-169) from the codling moth, Carpocapsa pomonella (with a review of culture of cells and tissues from Lepidoptera). Curr. Top. Microbiol. Imm., 55 : $19-27$.

HINK, W.F. and Ignoffo, C.M. 1970. Establishment of a new cell line (IMC-HZ-1) from ovaries of cotton bollworm moths, Heliothis zea (Boddie). Exp. Cell Res., $60: 307-9$.

HOWATSON, A.F. 1970. Vesicular stomatitis and related viruses. Adv. Virus Res., $16: 195-256$.

HOWATSON, A.F. and Whitmore, G.F. 1962. The development and structure of vesicular stomatitis virus. Virology, $16: 466-78$.

HSU, S.H. 1971. Preliminary observations on growth of arboviruses in a newly established line of mosquito cell (Culex quinquefasciatus Say). Curr. Top. Microbiol. Imm., 55 : $140-48$.

HSU, S.H., Liu, H.H. and Suitor, E.C., Jr. 1967. Adaptation of Grace's continuous line of mosquito (Aedes aegypti L) cells to hemolymph-free medium. J. Formosan Med. Ass. Abst. , 66 : 645.

HSU, S.H., Liu, H.H. and Suitor, E.C., Jr. 1969. Further description of a subline of Grace's mosquito (Aedes aegypti $L$ ) cells adapted to hemolymphfree medium. Mosquito News, $29: 439-46$.

HSU, S.H., Mao, W.H. and Cross, J.H. 1970. Establishment of a line of cells derived from ovarian tissue of Culex quinquefasciatus (Say). J. Med. Entom., $7: 703-7$.

HULL, B.P. 1970. Cocal virus infections in Swiss white mice. M. Sc. Thesis, McGill University.

JENKIN, H., Townsend, D., Makino, S. and Yang, T. 1971. Comparative lipid analysis of Aedes aegypti and monkey kidney cells (MK-2) cultivated in vitro. Curr. Top. Microbiol. Imm., $55: 97$ - 102.

JOHNSON, J.W. 1969. Growth of Venezuelan and eastern equine encephalomyelitis viruses in tissue cultures of minced Aedes aegypti larvae. Am. J. Trop. Med. Hyg., $18: 103-14$. 
xvii.

JOHNSON, J.W. 1971. Susceptibility of tissue cultures of minced Aedes aegypti pupae and adults to infection with Venezuelan equine encephalomyelitis virus. Am. J. Trop. Med. Hyg., 20: $761-64$.

JOHNSON, K.M., Tesh, R.B. and Peralta, P.H. 1969. Epidemiology of vesicular stomatitis virus: some new data and a hypothesis for transmission of the indiana serotype. J.A.V.M.A., $155: 2133-40$.

JONKERS, A.H. 1967. The epizootiology of the vesicular stomatitis viruses: a reappraisal. Am. J. Epid., 86: $286-91$.

JONKERS, A.H., Shope, R.E., Aitken, T.H.G. and Spence, L. 1964a. Cocal virus, a new agent in Trinidad related to vesicular stomatitis virus, type Indiana. Am. J. Vet. Res., 25: $236-42$.

JONKERS, A.H., Spence, L. and Aitken, T.H.G. 1965. Cocal virus epizootiology in Bush Bush Forest and the Nariva Swamp, Trinidad, W.I. I. Further studies. Am. J. Vet. Res., 26: $758-63$.

JONKERS, A.H., Spence, L., Coakwell, C.A. III and Thornton, J.J. 1964 b. Laboratory studies with wild rodents and viruses native to Trinidad. I. Studies on the behaviour of Cocal virus. Am. J. Trop. Med. Hyg., $13: 613-19$.

KAPLAN, M.M., Wiktor, T.J., Maes, R.F., Campbell, J.B. and Koprowski, H. 1967. Effect of polyions on the infectivity of rabies virus in tissue culture: construcrion of a single-cycle growth curve. J. Virol., 1 : $145-51$.

KELLY, M.W. and Dalgarno, L. 1971. The growth of arboviruses in continuously cultured mosquito cells. Proc. Aust. Biochem. Soc., $4: 76$.

KINDIG, D.A. and Kirsten, W.H. 1967. Virus-like particles in established murine cell lines: electron-microscopic observations. Science (Washington), 155 : $1543-45$.

KITAMURA, S. 1966. The in vitro cultivation of tissues from the mosquitoes. III Further studies on the cultivation of ovarian tissues of three mosquito species and the examination of the origin of cells grown in vitro. Kobe J. Med. Sci., 12:63-70.

KITAMURA, S. 1970. Establishment of cell line from Culex mosquito. Kobe J. Med. Sci., 16: $41-50$. 
xviii.

KOUROUPIS, G.M. and Sabina, L.R. 1971. Enhancement of vesicular stomatitis virus production by serum. Canad. J. Microbiol., $17: 1149-55$.

KOWALCZYK, T., Hanson, R.P. and Brandly, C.A. 1955. Infectivity and pathogenicity of vesicular stomatitis virus for ferrets. Am. J. Vet. Res., $\underline{16}: 180-82$.

LAM, K.S.K. and Marshall, I.D. 1968. Dual infection of Aedes aegypii with arboviruses. 1. Arboviruses that have no apparent cytopathic effect in the mosquito. Am. J. Trop. Med. Hyg., $17: 625-36$.

LANDUREAU, J.C. 1968. Cultures in vitro de cellules embryonnaires de Blattes. II. Obtention de lignées cellulaires a multiplication continue. Exp. Cell Res., 50 : $323-37$.

LEVINE, S. 1964. Effect of actinomycin D and puromycin dihydrochloride on action of interferon. Virology, $24: 586-88$.

LEWIS, M.R. 1S16. Sea water as a medium for tissue cultures. Anat. Record, $10: 287-99$.

LIBIKOVA, H. and Buckley, S.M. 1971. Studies with Kemerovo virus in Singh's Aedes cell lines. Acta Virol., $15: 393-403$.

LIEBHABER, H. and Takemoto, K.K. 1961. Alteration of plaque morphology of EMC virus with polycations. Virology, 14: $502-4$.

LYONS, M.J. and Heyduk, J. 1972. Comparative study of the interaction of California encephalitis virus with cultured vertebrate and arthropod cells. 72nd Ann. Meeting A.S. M. Abst. V56, p. 194.

MAGUIRE, T. and Miles, J.A.R. 1965. The arbovirus carrier state in tissue cultures. Arch. ges. Virusforsch., $15: 457-74$.

MERCK Veterinary Manual. 1967. 3rd ed. Ed. by Siegmund, O.H. Merck and Co., Rahway, New Jersey, pp. $280-82$.

MILES, J.A.R. and Austin, F.J. 1963. The formation of plaques in tissue culture by arboviruses. Aust. J. Exptl. Biol. Med. Sci., 41 : $199-204$.

MIRCHAMSY, H., Hazrati, A., Bahrami, S. and Shafyi, A. 1970. Growth and persistent infection of African horse-sickness virus in a mosquito cell line. Am. J. Vet. Res., 31 : $1755-61$. 
xix.

MITSUHASHI, J. 1967. Establishment of an insect cell strain persistently infected with an insect virus. Nature, $215: 863-64$.

MITSUHASHI, J. and Maramarasch, K. 1964. Leafhopper tissue culture: embryonic, nymphal and imaginal tissues from aseptic insects. Contrib. Boyce Thompson Inst. , 22 : $435-60$.

MIYAMOTO, K. and Gilden, R.V. 1971. Electron microscopic studies of tumor viruses 1. Entry of murine leukemia virus into mouse embryo fibroblasts. J. Virol. , 7 : $395-406$.

MUSSGAY, M. and Suárez, O. 1962. Multiplication of vesicular stomatitis virus in Aedes aegypti (L) mosquitoes. Virology, $17: 202-4$.

McCLAIN, M.E. and Hackett, A.J. 1968. A comparative study of the growth of vesicular stomatitis virus in five tiss'se culture systems. J. Immunol., $80: 356-61$.

NAGLE, S.C., Jr. 1969. Improved growth of mammalian and insect cells in media containing increased levels of choline. Appl. Microbiol., 17:318 - 19.

NAGLE, S.C., Jr., Crothers, W.C. and Hall, N.L. 1967. Growth of moth cells in suspension in hemolymph-free medium. Appl. Microbiol., 15 : $1497-98$.

PATTYN, S.R. and De Vleesschauwer, L. 1968. The multiplication of Middelburg $s$ and I plaque viruses in Aedes aegypti mosquitoes. Acta Virol., 12 : $347-54$.

PATTYN, S.R. and De Vleesschauwer, L. 1969. Plaque production by group A arboviruses. II. Enhancing effect of DEAE dextran on plaque numbers in chick embryo cells. Acta Virol., 13: $26-33$.

PATTYN, S.R. and De Vleesschauwer, L. 1970. The enhancing effect of diethylamino-ethyl dextran on the infectivity of arboviruses for Aedes aegypti. Arch. ges. Virusforsch., $31: 175-83$.

PAUL, S.D., Singh, K.R.P. and Bhat, U.K.M. 1969. A study on the cytopathic effect of arboviruses on cultures from Aedes albopictus cell line. Ind. J. Med. Res., 57 : $339-48$. 
PAVRI, K.M. and Ghosh, S.N. 1969. Complement-fixation tests for simultaneous isolation and identification of dengue viruses, using tissue cultures. Bull. Wld. Hlth. Org., 40 : $984-86$.

PELEG, J. 1965. Growth of mosquito tissues in vitro. Nature, 206 : $427-28$.

PELEG, J. 1966. Growth of Aedes aegypti embryonic cells and tissues in vitro. Experientia, $22: 555-56$.

PELEG, J. 1968. Growth of arboviruses in primary tissue culture of Aedes aegypti embryos. Am. J. Trop. Med. Hyg., $17: 219-23$.

PELEG, J. 1969a. Inapparent persistent virus infection in continuously grown Aedes aegypti mosquito cells. J. Gen. Virol., 5 : $463-71$.

PELEG, J. 1969b. Behaviour of infectious RNA from four different viruses in continuo'ssly subcultured Aedes aegypti mosquito embryo cells. Nature, $221: 193-94$.

PELEG, J. 1971. Attenuation of Semliki Forest (SF) virus in continuously cultured Aedes gegypti mosquito cells (Peleg) as a step in production of vaccines. Curr. Top. Microbiol. Imm., 55 : 155 - 61 .

PELEG, J. 1972. Studies on the behavior of arboviruses in an Aedes aegypti mosquito cell line (Peleg). Arch. ges. Virusforsch., $37: 54-61$.

PELEG, J. and Shahar, A. 1969. The establishment of Aedes aegypti mosquito cell lines. Symposium on behaviour of animal cells in culture, Proc. Nes Tsiyona : 40 .

PELEG, J. and Trager, W. 1963a. Growth of West Nile virus in insect tissue cultivated in vitro. Ann. Epiphyties, 14:211-12.

PELEG, J. and Trager, W. 1963b. Cultivation of insect tissues in vitro and their application to the study of arthropod-borne viruses. Am. J. Trop. Med. Hyg. , $12: 820-24$.

PERALTA, P.H. and Shelokov, A. 1966. Isolation and characterization of arboviruses from Almirante, Republic of Panama. Am. J. Trop. Med. Hyg., 15: $369-78$.

PERIES, J., Printz, P., Canivet, M. and Chuat, J.C. 1966. Multiplication du virus de la stomatite vésiculaire chez Drosophila melanogaster. C. R. Acad. Sci. (Paris), $262: 2106-7$. 
xxi.

PRINTZ, P. 1969. Propriétés du virus de la stomatite vésiculaire adapté à la Drosophile. Arch. ges. Virusforsch., $27: 209-20$.

PUDNEY, M. and Varma, M.G.R. 1971. Anopheles stephensi var. mysorensis: Establishment of a larval cell line (Mos. 43). Exp. Parasitol., 29 : $7-12$.

REHACEK, J. 1963. Propagation of tick-borne encephalitis (T.E.) virus in tick tissue cultures. Ann. Epiphytes, 14 : 199 - 204.

REHACEK, J. 1965a. Cultivation of different viruses in tick tissue cultures. Acta Virol., 9 : $332-37$.

REHACEK, J. 1965b. Relation between viruses and tick tissues in vitro. Proc. XII Int. Congr. Ent. London, pp. $774-75$.

REHACEK, J. 1968. The growth of arboviruses in mosquito cells in vitro. Acta Virol., 12 : $241-46$.

REHACEK, J. 1971. Present status of tick tissue culture. Curr. Top. Microbiol. Imm., 55 : 32 - 41 .

REHACEK, J., Dolan, T., Thompson, K., Fischer, R. G., Rehacek, Z. and Johnson, H. 1971. Cultivation of oncogenic viruses in mosquito cells in vitro. Curr. Top. Microbiol. Imm., 55 : $161-64$.

REHACEK, J. and Kozuch, O. 1964. Comparison of the susceptibility of primary tick and chick embryo cell cultures to small amounts of tick-borne encephalitis virus. Acta Virol., 8 : $470-71$.

REHACEK, J. and Kozuch, O. 1969. The use of Hyalomma dromedarii tick tissue cultures for the isolation of tick-borne encephalitis virus from its nature foci. Acta Virol., 13 : 253 .

REHACEK, J. and Pesek, J. 1960. Propagation of eastern equine encephalomyelitis virus in surviving tick tissues. Acta Virol., 4 : 241 - 45.

REHACEK, J., Rajcani, J. and Gresikova, M. 1969. Relationship of Tribec virus to tick cells and tissues. Acta Virol., $13: 439-42$.

RUSS, L.J. 1969. An antiviral substance from Penicillium Cyaneo-Fulvum:

Further studies. Ph. D. Thesis, McGill University. 
xxii.

RYSER, H.J.P. 1967. Studies on protein uptake by isolated tumor cells. III Apparent stimulations due to $\mathrm{pH}$, hypertonicity, polycations or dehydration and their relation to the enhanced penetration of infectious nucleic acids. J. Cell Biol., 32 : $737-50$.

SABIN, A.B. 1952. Research on dengue during World War II. Am. J. Trop. Med. Hyg., $1: 30-50$.

SANFORD, K., Earle, W.R. and Likely, G.D. 1948. The growth in vitro of single isolated tissue cells. J. Nat. Cancer Inst. , 9 : $229-46$.

SCHAFFER, F. L., Hackett, A.J. and Soergel, M.E. 1969. Vesicular stomatitis virus autointerference. Fed. Proc., 28 : $1867-74$.

SCHNEIDER, I. 1969. Establishment of three diploid cell lines of Anopheles stephensi (Diptera: Culicidae). J. Cell Biol., 42 : $603-6$.

SHECHMEISTER, I.L., Streckfuss, J. and St. John, R. 1967. Comparative pathogenicity of vesicular stomatitis virus and its plaque type mutants. Arch. ges. Virusforsch., $21: 127-32$.

SHELOKOV, A. and Peralta, P.H. 1967. Vesicular stomatitis virus Indiana type: an arbovirus infection of tropical sandflies and humans? Am. J. Epid., $86: 149-57$.

SHORTRIDGE, K.F., Pudney, M. and Varma, M.G.R. 1972. Infection of a mosquito cell line with human type 5 adenovirus. Ann. Trop. Med. Parasitol., $66: 363-68$.

SINGH, K.R.P. 1967. Cell cultures derived from larvae of Aedes albopictus (Skuse) and Aedes aegypti (L). Curr. Sci. , $36: 506-8$.

SINGH, K.R.P. 1971. Growth of arboviruses in Aedes albopictus and A. aegypti cell lines. Curr. Top. Microbiol. Imm., 55 : $127-33$.

SINGH, K.R.P. 1972. Growth of arboviruses in arthropod tissue culture. Adv. Virus Res., $17: 187-206$.

SINGH, K.R.P., Bhat, U.K.M. and Paul, S.D. 1971. Adaptation of Singh's Aedes albopictus (ATC-15) cell line to media with calf and goat sera and their susceptibility to infection with some arboviruses. Ind. J. Med. Res., $59: 31-34$. 
xxiii.

SINGH, K.R.P. and Paul, S.D. 1968a. Susceptibility of Aedes albopictus and Aedes aegypti cell lines to infection by arbo and other viruses. Ind. J. Med. Res., 56 : $815-20$.

SINGH, K.R.P. and Paul, S.D. 1968b. Multiplication of arboviruses in cell lines from Aedes albopictus and Aedes aegypti. Curr. Sci., $37: 65-67$.

SINGH, K.R.P. and Paul, S.D. 1969. Isolation of dengue viruses in Aedes albopictus cell cultures. Bull. WId. Hlth. Org. , $40: 982-83$.

SOHI, S.S. 1969. Adaptation of an Aedes gegypti cell line to hemolymph-free culture medium. Canad. J. Microbiol., 15 : 1197 - 1200.

SPURR, A.R. 1969. A low-viscosity epoxy resin embedding medium for electron microscopy. J. Ultrastruct. Res., $26: 31-43$.

STEVENS, T.M. 1970. Arbovirus replication in mosquito cell lines (Singh) grown in monolayer or suspension culture. Proc. Soc. Exp. Biol. Med., 134 : $356-61$.

STOLLAR, V., Shenk, T.E. and Stollar, B.D. 1972. Double-stranded RNA in hamster, chick, and mosquito cells infected with Sindbis virus. Virology, 47: 122 - 32 .

SUDIA, W.D., Fields, B.N. and Calisher, C.H. 1967. The isolation of vesicular stomatitis virus (Indiana strain) and other viruses from mosquitoes in New Mexico. Am. J. Epid., $86: 598$ - 602.

SUITOR, E.C., Jr. 1966. Growth of Japanese encephalitis virus in Grace's continuous line of moth cells. Virology, $30: 143-45$.

SUITOR, E.C., Jr. 1969. Plaque formation by an arbovirus in a mosquito cell line. J. Gen. Virol., 5 : 545 - 46.

SUITOR, E.C., Jr., Chang, L.L. and Liv, H.H. 1966. Establishment and characterization of a clone from Grace's in vitro cultured mosquito (Aedes aegypti L) cells. Exp. Cell Res., $\frac{44}{572}-78$.

SUITOR, E.C., Jr. and Paul, F.J. 1969. Syncytia formation of mosquito cell cultures mediated by Type 2 dengue virus. Virology, $38: 482-85$.

SWEET, B.H. and Dupree, L.T. 1968. Growth of cells derived from Culiseta inornata and Aedes vexans in tissue culture. A pre liminary note. Mosquito News, $28: 368-73$. 
xxiv.

SWEET, B.H. and Unthank, H.D. 1971. A comparative study of the viral susceptibility of monolayer and suspended mosquito cell lines. Curr. Top. Microbiol. Imm., 55 : 150 - 54 .

TAYLOR, J. 1964. Inhibition of interferon action by actinomycin. Biochem. Biophys. Res. Commun., $14: 447$ - 51 .

TESH, R.B., Chaniotis, B.N. and Johnson, K.M. 1971. Vesicular stomatitis virus, Indiana serotype: multiplication in and transmission by experimentally infected phlebotomine sandflies (Lutzmyia trapidoi). Am. J. Epid., 93 : 491 - 95.

TESH, R.B., Chaniotis, B.N. and Johnson, K.M. 1972. Vesicular stomatitis virus (Indiana serotype): transovarial transmission by phebotomine sandflies. Science, $175: 1477-79$.

TESH, R.B., Peralta, P.H. and Johnson, K. M. 1969. Ecologic studies of vesicular stomatitis virus I. Prevalence of infection among animals and humans living in an area of endemic VSV activity. Am. J. Epid., $90: 255-61$.

THORMAR, H. 1967. A comparison of Cocal and vesicular stomatitis yirus, serotypes New Jersey and Indiana. Virology, $31: 323-28$.

TRAGER, W. 1935. Cultivation of the virus of grasserie in silkworm tissue cultures. J. Exptl. Med., $61: 501-13$.

TRAGER, W. 1938. Multiplication of the virus of equine encephalomyelitis in surviving mosquito tissues. Am. J. Trop. Med., $18: 387-93$.

VARMA, M.G.R. and Pudney, M. 1969. The growth and serial passage of cell lines from Aedes aegypti (L) larvae in different media. J. Med. Entom., $6: 432-39$.

VARMA, M.G.R. and Pudney, M. 1971. Infection of Anopheles stephensi and Aedes aegypti cell lines with arboviruses isolated from Anopheline mosquitoes (Preliminary communication). Trans. R. Soc. Trop. Med. Hyg., $65: 102-3$.

WAGNER, R.R., Levy, A.H., Snyder, R.M., Ratcliff, G.A. and Hyatt, D.F. 1963. Biologic properties of two plaque variants of vesicular stomatitis virus (Indiana serotype). J. Immunol., 91 : 112 - 22. 
WALKER, D.L. 1964. The viral carrier state in animal cell cultures. Prog. Med. Virol., $6: 111-48$

WHITNEY, E. and Deibel, R. 1971. Growth studies of California encephalitis virus in two Aedes mosquito cell line cultures. Curr. Top. Microbiol. Imm. , $55: 138-39$.

WILNER, B.I. 1969. A classification of the major groups of human and other animal viruses. 4th Ed., Burgess Pub. Co., Minn.

WYATT, S.S. 1956. Culture in vitro of tissue from the silkworm, Bombyx mori L. J. Gen. Physiol., $39: 841-52$.

YANG, Y.J., Stolz, D.B. and Prevec, L. 1969. Growth of vesicular stomatitis virus in a continuous culture line of Antheraea eucalypti moth cells. J. Gen. Virol., 5 : $473-83$.

YOUNGNER, J.S. and Wertz, G. 1968. Interferon production in mice by vesicular stomatitis virus. J. Virol., 2 : $1360-61$.

YUNKER, C.E. 1971. Arthropod tissue culture in the study of arboviruses and rickettsiae: a review. Curr. Top. Microbiol. Imm., 55 : 113-26.

YUNKER, C.E. and Cory, J. 1967. Growth of Colorado tick fever (CTF) virus in primary tissue cultures of its vector, Dermacenter andersoni Stiles (Acarina : Ixodidae) with notes on tick tissue culture. Exp. Parasit., $20: 267-77$.

YUNKER, C.E. and Cory, J. 1968. Infection of Grace's Antheraea cells with arboviruses. Am. J. Trop. Med. Hyg. , $17: 889-93$.

YUNKER, C.E. and Cory, J. 1969. Colorado tick fever virus: Growth in a mosquito cell line. J. Virol., 3 : $631-32$.

YUNKER, C.E., Vaughn, J. L. and Cory, J. 1967. Adaptation of an insect cell line (Grace's Antheraea cells) to medium free of insect hemolymph. Science, $155: 1565-66$.

ZEE, Y.C., Hackett, A.J. and Talens, L. 1970. Vesicular stomatitis virus maturation sites in six different host cells. J. Gen. Virol., 7 : 95 - 102. 